\title{
SITES AND MONUMENTS
}




\section{AhmadABAD*}

Once the capital and still the premier city in Gujarat, Ahmadabad (Ahmedabad) is an old walled town standing on the east bank of the Sabarmati river, which has throughout the centuries enjoyed the reputation of being one of the fairest cities in the whole of India. The advent of industrialization, with mill and factory chimneys belching smoke, the streets filled with motor transport of every description, and urban sprawl and overcrowding resulting from the recent population explosion, have somewhat diminished Ahmadabad's glories; but most of its loveliness is still to be found, and it has been sadly unappreciated by most modern travellers.

Ahmad Shāh founded his new capital to the north of the old Hindu settlement of Ashaval. The new city, which replaced Anahilvada-Patan as the capital, covered an area of about 500 ha. The enclosure walls, some $5 \mathrm{~m}$. to $6 \mathrm{~m}$. tall, had original fourteen gates, and were defended by towers and bastions every $50 \mathrm{~m}$. or so; but an 18th-century source ascribes these to the time of Mahmūd 'Begrā', giving a chronogram, saying the specified parts were the responsibility of separate nobles. The walls are even described as being of Mughal date, since their internal construction is of red brick, but this is not referred to in the Mughal sources. None of this, of course, precludes the possibility of there having been an earlier mud or mud-brick wall.

On the west the city was defended by a wall following the almost straight line of the river bank. A temple to the goddess Bhadrakāli in pre-Muslim times has now utterly disappeared except for the reflection of its name in the Bhadra, of Bhadra Qil'a, the internal fort which constitutes the citadel, a square enclosure originally housing the royal palaces, and separated from the Maidān-i Shāh (royal grounds) to its east by a double gateway, of which the inner member stands imposingly between two enormous (later) circular bastions. (Excavations in recent times have revealed many fragments of Jain and Hindu temples in the

* "Mosques and Tombs," in Ahmadabad, eds., G. Michell and S. Shah, Bombay 1988, 30-119. [Hijra dates and diacritical marks added by the editor.] 
citadel area. There is now a comparatively modern Bhadrakālī temple within the area of A'zam Khān's caravanserai of 1047/1637.)

\section{The legacy of Islamic building before Ahmad Shāh}

Before we proceed to consider the mosques and tombs which are the glory of Ahmadabad we must recapitulate the principles of the growth of the Gujarati Islamic style. Islam has been implanted in Gujarat well over a century before the political rule of the Delhi Sultanate was shaken off and Ahmad Shāh's Sultanate came into being, with mosques established from the beginning, and the form of the mosque which had already evolved in Gujarat was there as an exemplar for Aḥmad Āhāh and his successors. The earliest mosques in Gujarat, to be sure, were mere improvisations arranged into a mosque form from pillaged temple material, as has happened all over India in the initial phase of an Islamic conquest, and were exemplified in the large but for some time ruinous Ādīna Masjid at the old capital, Patan. The Tānka Masjid at Dholka, in 762/1361, with its haphazard pillars from which human forms have been effaced, offers an extant example. Two further mosques will suffice to illustrate the development of the style, the Jāmi Masjids of Bharoch (722/1322) and Cambay (Khambayat) (725/1325). The former is entirely in the indigenous trabeate style, with an open prayer hall, its roof supported by richly carved pillars derived directly from the wealth of Hindu and Jain temple architecture. The exterior is comparatively plain, the outer walls being ornamented with nothing more than modest stringcourses, and a series of carved buttresses which indicate the presence inside of mihrābs; the only concession of traditional Islamic forms appears in the three large soaring domes which, with many smaller ones, dominate the skyline. The interior of the roof, though, shows the ornate cusped patterns and square coffered ceilings characteristic of the temple style, which were indeed probably temple spoil adapted to the purpose of the mosque. The Cambay mosque, on the other hand, is more assertively Islamic, for the façade of the prayer hall shows three well-proportioned arched openings, the central one taller than those flanking it, although the hall behind is in the trabeate style; the façade is also surmounted by a row of merlons of characteristic shape. The great courtyard has two water cisterns (tanks) underneath it - a typically Gujarati feature. A colonnade runs the length of the southern side of the mosque, its central part being a two-storeyed dodecagonal rotunda, entirely of pillars of typically Hindu 
or Jain style, which were doubtless produced by local craftsmen. The rotunda originally supported a large corbelled dome, with a superb tombstone below. The mosque walls are plain, as before, with simple Jain-like stringcourses, and the outer walls show alternate deep and narrow courses as in the Khaljī style, Delhi; but the pillared eastern porch is entirely in the local temple style, with seating slabs with sloping back rests (kakșäsanas).

\section{Monuments of the reign of Ahmad Shāh (814-46/1411-42)}

The earliest dated mosque in Ahmadabad is that of Ahmad Shāh himself, built in $817 / 1414$, in the south-west corner of the citadel, probably a private mosque for the use of the sultan and his immediate train (and hence other arrangements would have been necessary for the city's congregational mosque; probably a temporary structure served such needs under the great Jāmi` Masjid, described below, was completed). Here we have the immediate descendant of the Cambay mosque on a smaller scale: again there is an arched prayer hall façade of three arches, with the central bay raised above the level of the remainder, with the internal arrangements in the trabeate style (the central bay reveals two small pillars with a heavy stone lintel above them); and again the roof parapet is capped with a row of merlons. But here the central bay is flanked by two great but sparsely ornamented buttresses, which terminate at parapet level - the turrets above them having presumably fallen in the great earthquake of 1819; but even these are not an innovation of the Gujarati style, as there is a precedent for them in the mosque of Hilāl Khān Qāzī at Dholka. There is no evidence to determine whether these turrets were in fact minarets (the staircases in the thickness of the buttress give access to the roof, from where the call to prayer could have been given); but it is tempting to see them as the forerunners of the paired minarets which, at least in the earlier stages of the style, flank the central opening of the prayer hall, a peculiarly Gujarati feature. The raising of the central bay above the side roof levels has two consequences: firstly, the general appearance of the prayer hall is greatly enhanced by the change of level, relieving what could otherwise be a monotonous aspect in a long low building: and secondly, this practice allows air and light to enter the prayer hall much more freely, providing a sort of clearstorey. The vertical gap between the two roof levels is filled with stone screens, which reduce possible glare from oblique rays of the sun, and also prevent the entry of birds, and 
driving rain, at roof level. Both the clearstorey and the stone screens are to become further characteristics of the Gujarati style.

A smaller mosque, built within the next year or so, is that of Haybat Khān, a relation of Aḥmad Shāh; built almost entirely of temple spoil, the exterior aspect is severely plain, except for the five half-round buttresses behind the mihrāb wall; the corner buttresses taper, in the manner of the Tughluq style of Delhi. The interior shows all the rich flamboyance of the indigenous Hindu-Jain temple craft. The noble central dome - again over a chamber raised above the side aisles - reveals within that it is the roof of a temple mandapa taken over in its entirety. The curious feature here is the pair of slender cylindrical turrets set at the end of the parapet over the central arch, unornamented and obviously non-functional, rather like thinner versions of the pillars over the central arch of the 'Arhā'̄ din kā Jhōmprā Masjid at Ajmer. They represent, no doubt, a further stage in the search for the Gujarati minaret form; but they are minarets only in a psychological sense.

A modest mosque, undated, is that of Shakar Khān (probably a son of Aḥmad Shāh), near the Kālūpur Darwāza, possibly of about this time. It is almost entirely devoid of decoration (the pillars were obviously cut for the purpose), and is entirely trabeate, of the open pillared hall style. Good corbelled domes over the five main bays of the prayer chamber, which is of impressive strength. An unusual feature is that the pillars on the courtyard side are grouped in threes from east to west. Five half-round external buttresses mark the position of the internal mihrābs and these have rather more carved decoration. A staircase leads to the roof, and there is no trace of any sort of minaret.

Next comes the little mosque of Sayyid 'Ālam, c. 823/1420 (the inscription is fragmentary), where the central chamber is of three arches, considerably taller than the side wings which are entirely in the trabeate style. This also has a richly decorated interior, and fine pierced stone window screens; but here the central arch of the façade is flanked by a pair of ornate buttresses which end at parapet level in semicircular platforms supported by heavy stone corbelled brackets; though there is now nothing above them, perhaps we have here at last the beginnings of the true Gujarati minaret, for the construction of this mosque was concurrent with that of the great Jāmi` Masjid, Aḥmad Shāh's greatest work, to which we now turn.

The Jāmi 'Masjid was completed in 827/1424, although it had obviously been many years in building. The harmony of solids and voids of its noble façade makes it one of the loveliest mosques in India, 
and when it was built it was probably the largest in the subcontinent (although later eclipsed in size by those of Lahore and, much later, Bhopal). The whole conception is grandiose, for the vast paved courtyard is a rectangle of about $75 \mathrm{~m}$. by $66 \mathrm{~m}$; the north, east and south boundaries are enclosed by open colonnades along the stone walls, with a long ablution tank in the middle-here, unfortunately, the area is protected from the sun by a modern roof on thin struts, looking all too much like a bicycle shed! The west side is filled by the prayer hall, the builders having avoided any suspicion of monotony in such a long structure by arranging the roofs on three levels: the extreme north and south chambers are the lowest, opening to the courtyard by five pillared bays of unequal size, not structurally arched but rather showing an arch-shaped infilling at the top supported on corbels, a device known also in the early buildings at Dhar and Mandu; the central chamber is of three arched bays on two levels, the roof of the side bay at the second level carried on pillars with perforated stone screens between them, with a similar arrangement carrying the central bay above the side bays. The whole of the western chamber is a great hypostyle hall, a forest of 260 pillars, all with restrained decoration directly derived from the temple styles, so disposed as to form three rows of five square bays each, every one with a dome above. The three front central bays, with their extra height provided by the clearstoreys, are most impressive, the middle one forming a sort of central rotunda. The two tall pillars which are seen from the courtyard within the central arch have an additional embellishment in the form of a cusped semicircular arch carried on corbels just below the top beam, again a feature of Gujarati temple architecture as at, for example, the magnificent Sūrya temple at Modhera. The façade shows, flanking the central arch, sumptuously decorated buttresses, the bases of the minarets which fell in the 1819 earthquake; and these are certainly real minarets at last, as an old drawing makes clear.

A grandiose conception indeed; but the mosque alone is only part of Aḥmad Shāh's vision. The mosque is built so that its northern wall lies along a royal processional way, leading eastward from the Maidān-i Shāh already referred to, which was entered at its eastern end by a great triple gateway (T̄̄n Darwāza), its central arch wider than the flanking ones, two buttress projecting from the inner piers similar to the decorated minaret-bases in the mosques, with a deep parapet above in which there are three roofed balconies projected on corbelled brackets. The Maidān-i Shāh (which has been completely obliterated by modern 
development) extended from the Tīn Darwāza to the east gateway of the citadel, with streets off it to the north leading to quarters ancillary to the necessities of the palace. It had a central chabutra (raised platform) which may have formed part of the original system for the royal water supply (a neighbouring street bore the name 'Karanj', a corruption of the Persian kariz, 'underground water channel'; and clay pipes were found here during reconstruction work). The maidān also had a postern on its southern side. The 'royal precinct' scheme is completed by two other works: an enclosure set aside in Ahmad Shāh's time, east of the mosque, to contain his tomb, and a further enclosure to be dedicated to the tombs of the royal ladies.

\section{Monuments of the reign of Muhammad Shāh (846-55/1442-51)}

The two works last mentioned were in fact completed in the reign of Ahmad Shāh's son and successor Muhammad. The tomb of Ahmad Shāh, itself unspectacular as a building, is nevertheless of importance in architectural history: the pillars supporting the roof are composed so as to form a sort of cloister around the square domed central chamber, which is separated from the cloister by perforated screens of stone in square patterns: another characteristically Gujarati feature. The tombs of the queens (Rānī ka Hāzīra) are, by contrast, set in an open courtyard, which stands imposingly on a very high plinth, within pillared galleries; and here there are exquisite screened windows separating the outer corridors from the outside world. The tombstones of marble, inside the courtyard, are superb examples of the stone carver's art.

This reign sees the beginning of another great architectural project, his time at Sarkhej, some $10 \mathrm{~km}$. south-west of Ahmadabad, with a fine monumental tomb and an elegant mosque. The tomb was built for Shaykh Ahmad Khațțū, known as 'Ganj Bakhsh', who died here in his retirement at the age of 111 lunar years in 850/1446. Essentially a domed central chamber surrounded by four ranges of pillared corridors, it is the largest of its type; the central chamber is separated from the outer corridors by perforated stone screens, arch-shaped below with the commoner small square screens above, giving the outer façades a two-storeyed effect, although the interior is the one tall storey. The central dome - which sits rather uneasily on its support, since this is an unequal octagon, as though its builders were unaccustomed to using this form with fluency - is surrounded by smaller domes over the bays of the outer corridors. The mosque, by contrast, is a completely open 
building with the arch used not at all, the western prayer hall presenting a view of a forest of simple pillars, taller than those of the one-bay-deep corridors which surround the remaining three sides. An open pavilion to the south of the tomb completes this stage of the building; but the sanctity of the site attracted an immense but completely harmonious development at Sarkhej towards the end of the 15th century under Maḥmud 'Begrā'.

\section{Monuments of the reign of Outbuddin Ahmad Shāh (855-62/1451-58)}

A few buildings produced in the short reign of Qutbuddin Ahmad Shāh show the progression of the same style. The mosque in the city carrying his name (which, however, bears the date 853/1449, in the previous reign) is on a modest scale and similar to Ahmad Shāh's mosque, except that the central buttresses, the minaret bases, are more robust and exquisitely decorated. The mosque of his mother ('Bībî̀j') in the Rājpur locality (858/1454) is instructive, for one of its paired central minarets is still standing intact, showing three circular galleries round the tapering shaft, supported on heavy corbels, the topmost level of the minaret opening by an arched door to the courtyard and capped by a conical roof. In this mosque instead of open pillared chambers in the north and south wings of the prayer hall are three elegant arches, the side ones closed by seat-backs, the taller central one open to the courtyard. The mosque and tomb of Malik Shā'bān both bear inscriptions with the date 856/1452; they are widely separated, since the mosque is in the city and the tomb lies in Rakhiyāl, on the eastern outskirts, adjoining a tank built by the malik's order which has now been converted into a stadium. And both present unusual features: the tomb is a pillared square hall inside a large square enclosure with corner chhatris, its central chamber carrying a large dome without a clearstorey, with the surrounding colonnade entirely covered by flat roofs except for very shallow domes at the corners. The mosque façade is open, revealing a double row of pillars in the front, with openings of unequal size; but the plan is most remarkable: the westernmost section is a chamber three bays wide, each with a mihrāb; two bays flanking this to the north and south, again with mihrābs, lie forward of this western end, and the main hall, wider again by one bay on each end (with a further mihräb niche in each), is set further forward still. There is a single large dome. The western view of this mosque has therefore as stepped appearance, which J. Burgess (The Muhammadan architecture of 
Ahmadabad, 2 vols., $A S W I$, vii and viii [= ASI NS, xxiv and xxxiii], Calcutta 1900 and 1905) and others following him have likened to a Hindu mandapa, declaring further that the mosque is nothing but a converted mandapa. But this seems unlikely, since the mandapa is a generally an open structure, whereas this mosque has of course a solid stone wall at its western end; it seems more likely that it may have been inspired by a mandapa shape, but even so it is curious that this is the sole example of this form. Also in this reign the Kankāriyā tank was excavated, 1 $\mathrm{km}$. outside the city wall, a polygon of 34 sides with a circuit of 1.25 $\mathrm{km}$.; steps of cut stone descend to water-level, and even so utilitarian a feature as a sluice is tastefully decorated with carving. The area around the tank was used as a camping-ground in Mughal times.

\section{Monuments of the reign of Mahmūd Shāh 'Begrāa' (862-917/1458-1511)}

The Gujarat style reached its apogee during the reign of Sulțān Mahmūd 'Begrā', who reached out beyond the bounds of Ahmadabad, founding new cities at Junagadh, Champaner and Mahmudabad (of which the first two cannot concern us here), adding greatly to the building complex at Sarkhej, and continuing to grace Ahmadabad with exquisite examples of the building art. Of these perhaps the earliest are the mosque and tomb of Sayyid 'Uthmān, c. 864/1460, at Usmānpur across the river; the tomb is a beautifully proportioned domed building, although it appears very low for its length, entirely constructed in the pillared style (but with the enclosing stone screens now unfortunately missing), and the mosque also has the open pillared façade with no arches. In both cases the employment of paired pillars at intervals gives additional interest to the scheme. Here the dome is handled with greater competence in earlier examples, for its circular base rests on a dodecagon, supported by extra pillars surrounding the tomb chamber. The mosque has tall minarets, placed here at the ends of the façade rather than centrally, well decorated with their six storeys, but perhaps a shade too dominating. The mosque of Dastūr Khān, with an inscription of $867 / 1463$, is almost square, about $30 \mathrm{~m}$. by $34 \mathrm{~m}$., constructed on a very high plinth, with a sort of cloister, one bay deep and domed all over, on the north, east and south, running directly into the western prayer chamber; the cloister opens to the courtyard by pillars, while exquisitely carved perforated screens divide it from the outside. The ablution tank in the courtyard is connected to a reservoir of almost the same extent as the courtyard itself. Two arcuate mosques, both showing 
an accomplished integration of the arcuate and trabeate styles, are of much the same time, those of Miyān Khān Chishtī (c. 869/1465) and Bībī Achyut Kūkī (874/1469), where the minaret bases flank the central of three arches, but these again are rather over-elaborate and tend to dominate the structures. The ornate minarets of the former mosque are crowned with domical tops, but since these are not typical of the time they may be restorations of a later period. The southern bays of the prayer chamber and part of the back wall were unfortunately tastelessly altered to make the accommodation for a Railways' engineer in the mid-1870s. Bībī Achyut's mosque, and her tomb in the form of a small pillared pavilion, lie within a large rectangular enclosure with round towers at the corners, unknown elsewhere in Gujarat.

Two aberrant structures must be mentioned here, as they probably represent an extraneous influence in Gujarati architecture. These are two monumental tombs, one of Daryā Khān, once a minister of Maḥmūd Shāh, and a tomb on the Sarkhej road known as A'zamMu'azzam, popularly declared to be the builders of Sarkhej. Both are of considerable size, and unlike anything else of their period in Ahmadabad are built almost entirely of brick and in the arcuate style throughout. Daryā Khān's tomb (857/1453), the largest brick tomb in Gujarat, has a tall heavy central dome on a tall circular drum, with arched verandahs on the four sides with smaller domes above, all carried on brick squinches rather than the indigenous beam-and-bracket, and looks as though it would be more in place in Delhi; it is at best a gloomy building, and I have been told that it is haunted. The A'zamMu'azzam tomb is also square, but with a much shallower dome, here not carried on a drum, three well-proportioned blind arches on each face with an upper gallery of smaller open arches, with a great tapering domed turret at each angle, rather like those of some of the buildings of the late Tughluqs and Lōdīs at Delhi. (For completeness we might mention another brick building, Alif Khān's Mosque in Dholka, where the three domes are supported in much the same way as in the A'zamMu'azzam tomb. The scale is enormous, and in spite of its ruinous condition it is most imposing.)

These are admittedly isolated specimens; but they may have pointed the constructional way to a further arcuate building, this time in stone: the tomb (and its associated complex) of the saint (Burhānuddin) Qutb-i 'Ālam, the grandson of a famous saint of Uchh, who came to Ahmad Shāh's court and died there in 856/1452, at Vāṭā, some 8 km. southeast of the city walls. This is a two-storeyed structure, of which the upper 
storey is a square room immediately over the tomb chamber, opening to the air by three arches on each side; above this is the dome, which originally had a small chhatri in each corner (only one of these now remains). The ground floor storey has a broad inner arcade on each side of the tomb chamber, with a narrower outer arcade; and the pillar-and-lintel form of construction appears only in the entrance porch. But the builders ere evidently still unaccustomed to working with the arched form, for the outer arcades have not withstood the force of the lateral thrust, their arches have largely fallen, "and the whole is very much crippled, while the tomb without arches, that stand within a few yards of it, remains entire" ( J. Fergusson, History of Indian and Eastern architecture, London 1876, 535). The tomb was formerly attributed to the reign of Mahmūd 'Begrā', but its date is in fact uncertain. I have recently heard it suggested that it might even be early Mughal; but in my opinion no Mughal architect would have handled the arcuate style with such incompetence. Not only the minor tomb but also the mosque attached to the complex is entirely in the trabeate style.

And the trabeate style continued to be popular. The great complex known as Shāh 'Ālam, constructed over many years, is considered later below, although its foundation may have begun shortly after the saint's death in 880/1475. And Mahmūd's personal building scheme, extending the Sarkhej complex, relies very largely on the beam-andbracket. He caused to be excavated, by the side of the great mosque, a vast lake; steps down to the water were added to one side by the mosque courtyard. At the east end of the north side of the lake were built, in the shadow of the tomb of Shaykh Ahmad Khațtū, two magnificent tombs, one for Mahmūd Shāh, and another, connected by a portico, for his queen Bībī Rājbai; both of these are of the trabeate style, domed, and with the central tomb chamber surrounded by elaborate stone screens. At the west end of the south side of the lake is Mahmund's palace, again almost entirely trabeate, but now in a sad state of disrepair; and the sluice gates to the tank are again treated with great attention to proportion and decoration. (An inscription in Gujaratī prose, in Nagarī characters, declares that the tank was built by 'Madapharsa', i.e., Muzaffar Shāh, in 920/1514; this is, of course, later than the tombs of Mahmud Shāh and his queens, and the palace building, which were obviously sited with reference to a large extent of water. It may simply refer to the completion of the works, or to some other works of importance.) 
Mahmūd had by now built his new capital of Champaner. But excellent building works continued at Ahmadabad. The mosque of Muhāfiz Khān, 890/1485, a comparatively small one, has the richly carved minarets at the end of the prayer hall arcuate façade rather than flanking the central arch; and they are lower, having only three storeys above roof level, than in some other examples, investing the ensemble with more coherence. The difference in elevation between the central chamber and the side bays is not apparent form the courtyard, where the façade conceals the arrangement; but the attractive rear view of the mosque reveals this, and also the decorated oriel windows which project from the sides of the sanctuary. The mosques of Bāī Harīr, 906/1500, in Asārvā, and Rānī Rūpāvatī in the Mirzāpur quarter, of about the same date, have the minarets placed centrally, and show an interesting integration of the arcuate and trabeate forms in the elaborate north and south extensions to the prayer chamber, with their balcony openings on the façade very much in the old temple style; but although the decoration of the minaret buttresses in both of these is very ornate, there is something of a heaviness about both. The former building has the small tomb of the founder beside it, and a magnificent $v \bar{a} v$, or step-well; the latter also has an associated tomb.

\section{Buildings of the later sultāns}

Some very fine buildings continued to be produced in the subsequent reigns of Muzaffar II (917-32/1511-26), Bahādur (932-43/1526-37) and Mahmūd III (943-61/1537-54), even if the style in general was losing something of its vigour. Foremost are unquestionably the mosque and tomb of Rānī Sabrā'̀ (commonly but incorrectly called Sipari) of 920/1514; Fergusson (op. cit., 534) describes the mosque as "the most exquisite gem at Ahmadabad, both in plan and detail." Both are of small scale, the square tomb, with an upper storey above the central chamber, being superbly screened all round, and ornately carved; the mosque is the open-fronted pillared variety, with no clearstorey, and bearing at the ends of the façade tall slender pillars. These are not functional minarets, for they are solid, sculptured along their entire height. The small Gumti mosque, in İsānpur, has similar solid minarets at the ends of the façade, and similar paired pillars at the opening, without the richness of decoration. Other mosques of much the same general design are Ibrahīm Fayyad's, on the road to the tomb complex 
of Shāh 'Ālam; an elegant small stone mosque in Pālḍi-Kochrab, sometimes known as Bāwa 'Ali Shāh's mosque, with superb merlons in many patterns of open carved tracery; Shāh Khub Sayyid Muhammad Chishtî's mosque, with an inscription of 945/1538; Darvesh 'Alī's mosque, another architectural gem, with an inscription declaring it to have been built by Bībī Khūnja in 910/1505 (thus making it the earliest of this type), which has an associated tomb; and the Fațeh mosque in the north-east corner of the city, with a courtyard tomb which appears to be very much older. They would all seem to belong to the first half of the 16th century.

Also at, or rather just outside, İsānpur is a large tomb-and-mosque complex, the Rauza of 'Imādul-Mulk Malik 'Isān, probably from the early years of Muzaffar II's reign, which has a character of its own; for the whole complex lies within an enclosure wall with pillared corridors all round; the north and south corridors lead in to the domed wings of the prayer hall, whose façade is in advance of that of the wings, and is raised above their level to form a clearstorey; the weight and thrust of this superstructure is taken by pairing the front pillars; the three arches of the central chamber soar above the level of the wing roofs, and the central one is cusped; and there are no minarets at all, nor a means of access to the roof. The tomb, entirely trabeate, stands within the courtyard, and the whole presents a harmonious and integrated structure.

Harking back to the older style of, say the Bāi Harīr and Rānī Rūpāvatī mosques is the mosque of Malik Sārang in Sārangpur, a quarter in the east of the walled city, where the malik was governor under Muzaffar II in the 1520s; the mosque may well have been started earlier, but there is no firm evidence for an earlier date. It has a broad façade of five arches, the central one raised above the level of the side bays, and more sumptuously decorated than the remainder, flanked by two massive minaret bases which are decorated with superb carved panels which seem to come from different periods (some, perhaps, since they resemble panels on the Jāmi Masjid, may have been earlier pieces of Hindu or Jain workmanship reutilized); but whatever the period they show the fluency and plasticity the local artisans were able to achieve in sandstone carving. The minarets terminate at roof level, having been taken down (by inept P.W.D. conservation work) in the 19th century; fortunately an old photograph shows the richness of the 
northern minaret. A short distance opposite the mosque on the east is what remains of what must have once been once of the most splendid pillared mausoleums, now somewhat vandalized.

The complex containing principally the tomb and tank (Mustafar-Sar) of Shāh 'Âlam, the son of Qutb-i 'Ālam of Vāṭā, was executed in 938/1532; the mosque may be later, and the minarets of the mosque may have been added later still. The tomb building, which has been described as one of the most beautiful in Gujarat, is again of the double-screened type: the outer arcade opens to the courtyard by arched openings, of which the tympana are filled with stone screens; on the west front there is also a tall portico. The internal construction is entirely trabeate, an inner square of twenty pillars forming a double corridor around the inner twelve pillars which enclose the tomb chamber itself, above which is the large dome, with a painted interior, supported on a clearstorey. This inner chamber is surrounded by rich pierced marble screens within the twelve pillars; and the sarcophagus itself is further surrounded by a perforated marble screen. The inner door to the tomb chamber, between the marble screens, is itself filled with intricate brass-work panels, but of a later date but entirely harmonious, and the device over the lintel is worthy of remark here: the sinuous line in fact represents the ancient design of the torana, especially common in Jain building. (This is by no means an innovation, for it is a favourite decorative device in the mihräbs of Gujarati mosques. It is one of the characteristic Gujarati forms to be transported to other regions.) The mosque, by contrast, is entirely arcuate; the façade is of seven arches, numbers two, four and six being wider than the other four; this results in a pleasant irregularity in the bays of the prayer hall: the larger square bays are covered by large domes, with smaller domes over the remaining square areas, and pyramidal roofs over the oblong ones. These are all carried by pendentives between the arches, much in the late Lōdī manner of Delhi. At the two ends of the prayer hall are tall minarets, set forward about $3 \mathrm{~m}$. from the façade, bearing four galleries supported on heavy corbelled brackets. The courtyard is most interesting, for there is a large vaulted reservoir beneath its floor, providing water for the ablution tank in the north-east corner of the mosque courtyard (this is also a Gujarati feature, known from earliest times, later echoed in other areas of Muslim India). Another large pillared tomb, and hundreds of graves, lie south of the main area; there 
are many smaller halls, used for the reception of guests and pilgrims at the anniversary celebrations ('urs) of the saint's death, and an imposing outer gateway to the site.

An unusual mosque, like that of Shāh 'Ālam, constructed entirely on entirely arcuate principles, is that of Muhammad Ghaus Gwāliyāri, c. 957/1550, with very fine pendentives between the arches; but its extraordinarily distinguished feature, a sort of central propylon of stone with a triple-arched entry, was ineptly dismantled by the P.W.D. in the 1880s. "This entirely changed the appearance of the façade - depriving it of all dignity" (Burgess, op. cit., 1905, 49). From an old photograph which shows this feature virtually intact, it would appear that the mosque resembled those of Jaunpur, in eastern Uttar Pradesh, rather than anywhere else. But it also has one tall minaret at the north end of the façade, six storeys above the parapet level and octagonal in crosssection - a shape found in no other Gujarati building; a larger and plainer octagonal buttress at the south end, which contains a stairway to the roof, was apparently never completed. Minarets, however, were never used in the Jaunpur style. All that can be considered typically Gujarati here is the quality of the stonework, and the restrained use of stringcourses; even the interior mihrābs are not of the usual pattern. However, it is worth recalling that Muhammad Ghaus, after his death in 969/1562, was buried in Gwalior, in a tomb which displays many Gujarati features.

In the Shāhpur quarter, in the north-west corner of the walled city, is the imposing mosque built by Shakyh Hasan Muhammad Chisht̄̄ in 973/1565; his descendants became hereditary qazis of this ward, and the building is sometimes called simply Qazi's mosque. The façade of the prayer chamber, with very fine carving, is of nine tall arches, the two flanking the central arch narrower than the rest, to be in alignment with the arrangement of pillars supporting the dome. Over the central five bays, and running the entire depth of the prayer chamber, is an upper storey of five pillared openings, with a balcony on heavy brackets projecting over the central arch. There are massive minaret bases at the ends of the façade, but it appears that the minarets themselves were never completed. Burgess (op. cit., 1905, 45) is worth quoting verbatim: "The minarets, so far as executed, are exuberantly rich in their carvings: in this respect, indeed, they are among the most elaborate in Gujarat, and the traceries of the niches have attracted much attention, as surpassing almost all others." The general design of this mosque closely resembles that of Bābā Lulu'i's mosque in Behrāmpur, $1.5 \mathrm{~km}$. south 
of the city walls; but here the upper storey is of three pillared openings only on each face, and there are also four smaller domes around it on the roof. The minaret bases are nearly the equal of those of the Shāhpur mosque in their carved decoration.

In the village of Sojali, $3 \mathrm{~km}$. outside one of Mahmūd I's new cities, Mahmudabad (now called Mehmedabad), about $22 \mathrm{~km}$. south-east of Ahmadabad, is the tomb of Sayyid Mubārak Bukhāri, built after 966/1588, a superb example of the arcuate style, although its ground floor is much the same as that of the Shāh 'Ālam tomb. The outer row of piers, however, is simply open arches without screens, and screens appear only around the central tomb chamber. This is surmounted by a large dome on tall drum, where there is the innovation of a clearstorey provided within the drum by pointed arches filled with screens. There are four small chhatris around the dome, and a large chhatri over the entrance porch, which, with the shallow domes over the bays of the side arcades, provide a lively interest to the skyline; but we have already seen chhatrīs in use at the Vāțā tomb, and they are also freely used over the entrance porches at the Jāmi ${ }^{`}$ Masjid in Champaner. The tomb, standing above the river, was formerly contained in a buttressed enclosure. There is no attached mosque, but a small tomb to the southwest, in a separate enclosure, attributed to Nizāam al-Dīn, is of similar design but in brick throughout; this has a small qanāti mosque on the west wall of the enclosure.

During the first decline of the Gujarat Sultanate a faction of habshis, men of African slave stock, had become powerful in some regions of the state. One prominent member of this community, Sidi Sa îd, caused a mosque to be built, in 980/1572, in Ahmadabad, just outside the north-east corner of the citadel, which can perhaps be counted the last great building in the Gujarati style before the Mughal conquest. Sidi Sa îd's mosque is again in the purely arcuate style, five bays wide and three bays deep, with broad buttresses at the ends of the façade which may have formerly supported minarets. What makes this little mosque so distinguished is its ten window screens which fill the tympana of the side and rear arches; those in the side walls, and two in the bays of the back wall, are filled with the usual square stone pierced panels in geometrical and vegetal designs, but those of the two bays flanking the central aisle are whole slabs of pierced intertwining tree and foliage designs, in one a 'palm and parasite' motif combining the superb sculptural skill of the carvings already seen on some of the minaret buttresses with the flowing form derived from that ancient Islamic device, 
the arabesque, and a 'four palms' device in the other, scarcelessly less elaborate. There are no screens anywhere else in India to compare with these in either skill or beauty, although an imitation of one design occurs in one of Akbar's early buildings in Fatehpur Sikri.

The account of the Gujarati style of Ahmadabad would not be complete without mention of the famous step-wells (vāv), whose origin was certainly pre-Muslim, which are developed in a characteristic way not evinced in the ordinary step-wells, or $b \vec{a}$ o $l \bar{\imath}$, of North India.

\section{Monuments of the Mughal period}

By the time of the Mughal conquest many of the traditional Gujarati stoneworkers had already drifted away, attracted by the wealth and greater prospects of getting work in the Mughal courts of North India. By the time Gujarat was settled under the new regime, the old craftsmen were gone; but buildings were of course still required. So either craftsmen trained elsewhere must have been drafted, or the original Gujarati craftsmen or their descendants returned imbued with new ideals learned in a foreign land. At any rate the essential styles of building underwent a radical change, with just enough of the indigenous traditions persisting to give the Gujarat-Mughal vernacular a local accent. Much of the building is, frankly, ugly and ill-proportioned, and only a selection of the better works is worth considering here.

In Ahmadabad the first major Mughal monument is the tomb of Mir Abu Turab, a leading noble who had conveyed the invitation to Akbar to invade the ailing Gujarat Sultanate in 980/1572, and who died in the imperial service in 1005/1597. The tomb is of modest size, about $12 \mathrm{~m}$. square, and entirely arcuate; a central chamber carries a dome on a square clearstorey; the surrounding arcade roof carries smaller fluted domes, as does a small southern entrance porch. The clearstorey walls still bear perforated screens, and there were originally screens around the tomb chamber which have long since been carried off (as has the marble of the tomb). It thus had considerable affinities with the late sultanate style, as exemplified in Bābā Lulu'i's or Shaykh Hasan's mosques.

Within the walled city, a little north of the citadel walls, is the Rauza of Shaykh Wajihuddin, a Sūfi scholar and teacher of great eminence, at one time a disciple of Shaykh Muhammad Ghaus Gwāliyāri, consisting of a mausoleum with an attached mosque and tank. Wajihuddin died in Ahmadabad in 997/1589, and a mausoleum was built a few years 
later during the time of Murtaza Khān Bukhāri, who was governor of Gujarat between 1606 and 1609. In the mausoleum the tomb chamber does not occupy the usual central position, but rather a square area at one end, covered by a square tower surmounted by a bulbous dome on a cylindrical drum; the rest of the roof area bears thirteen small low domes. The surrounding solid walls distinguish door and window openings (the latter come down to floor level) by the window openings being simple pointed arches, while the door openings have square heads, thus adding interest to the façade. The window openings are filled with screens, and the ensemble, in spite of its bulbous dome (seen in Gujarat here for the first time), is interesting and harmonious. It has been suggested that the tombs was originally square, with a central dome, and that the other end was added later. If this is so, the builders must have been competent in concealing any joint.

About $2.5 \mathrm{~km}$. north of the Delhi Darwāza of the city, on the left bank of the Sabarmati river, is the Shāhi Bāgh, a royal garden-palace, built in 1031/1622 by Prince Kurram, the future Shāhjahān, when he was viceroy of Gujarat. The garden fell into decay and was reduced in size, but it is obvious from the accounts of travellers (for example Thévenot) that it must have been a typical Mughal 'four-square' garden, or chār-bāgh, a square area divided into four parts by crossing central walks. The palace was (before modern additions) a large square block two storeys in height, standing over a sort of lower ground floor, or half-basement, intended to be a cool retreat in the hot weather. A large square room ('dārbār hall') in the centre of the ground floor has a splendid ceiling of moulded stucco, of a type familiar in the Mughal buildings of North India; the octagonal rooms adjoining it are contained on the upper storey with their shape emphasized by setting the central space back from the parapet of the ground floor. The builders have produced an interesting interplay of the shapes of the openings: on the river front there are four-centred arches, with a surface decoration of half-sized, blind four-centred arches, while the upper storey has three central openings spanned by beams of a shape again familiar in Mughal North India; on the garden front, however, this arrangement of the shapes of openings on the two storeys is reversed. The building has suffered much after the decline of the Mughal power by being modified for use as the residence of various officials, but the essential nobility of the main block is still apparent.

A modest but attractive building, in the middle of the walled city, is the Rauza of Shaykh bin 'Abdullāh al-Aidrus, who died in 1032/1623, 
a square structure with three arches on each side, with perforated stone panelled screens and a single dome above, whose base is decorated with a ring of cusped merlon shapes; a heavy eaves course, supported by carved brackets, surrounds the chamber.

A'zam Khān, perhaps the most efficient and industrious of the viceroys of Gujarat (1035-52/1626-42), has many building projects to his credit throughout Gujarat, whence his nickname of Udhai, 'white ant'. In 1047/1637 he built in Ahmadabad an extensive caravanserai and qaisariyya (market) (this is often referred to as his 'palace', but was not in fact his residence) adjacent to the entrance to the citadel (the massive round towers flanking the citadel gates are also attributed to him). The caravanserai has a fine eastern gateway leading to a large court, some 47 by $44 \mathrm{~m}$., with two storeys of open-fronted rooms on three sides for the accommodation of travellers; a Persian wheel within the courtyard brought water from the river for the travellers' needs. The entrance gate, $5.5 \mathrm{~m}$. high, has a great central arch occupying half the frontage, leading to an open half-dome; a smaller arch at the rear of that dome leads to an octagonal hall within, where there was a projecting gallery with a low balcony, with cut-stone screens, in front of it. The central arch of the façade is flanked by walls carrying a covered balcony supported on heavy brackets in the upper part of each side, with a blind arch below, and the whole entrance, set forward of the face of the whole building, has its sides chamfered off to produce an octagonal shape. The result is that the whole gateway looks as though it could have come from a Mughal palace in North India - very similar, in fact, to that of the so-called Jahāngīri Mahall in Agra Fort. In one corner of the building is a tahkhanna (basement) chamber with an ornamental cistern and fountain. This may have been supplied by the underground water-system mentioned above as supplying the Maidān-i Shāh. The interior arrangements of the caravanserai were much modified in the British period, after 1817, when the building was converted into the central jail.

Of a totally different style are the mosque and tomb of Nawwāb Sardar Khān, in the Jamālpur quarter of the walled city. He was a court noble of the time of Aurangzīb who had earned the emperor's gratitude by refusing to admit the unfortunate Prince Dārā Shukoh into Ahmadabad in 1070/1659; he was later for 20 years governor of Saurashtra, where he laid out his beautiful Sardār Bāgh in Junagadh where there is an exactly similar mosque. He was finally sent to Thatta in Sindh, where he died in 1095/1685; his body was brought back to 
lie in the tomb he had built himself, which formerly bore an inscription dating it to 1684 . Tomb and mosque lay within a high walled enclosure with a high gateway, but are now closely surrounded by habitation. The mosque, built of brick covered with lime-plaster, is of three arched bays, with two pseudo-minarets at the ends (they are solid, with no means of access to the mosque roof), and the prayer chamber is surmounted by three domes of a somewhat exaggerated onion shape, capped by heavy finials above a ring of foliation. The tops of the pseudo-minarets are similarly treated, with even heavier foliations, and the whole building looks top-heavy. The tomb is in much the same style, even more open to the charge of top-heaviness by having its large central onion-shaped dome surrounded by eight smaller ones of similar shape. Even the high gateway has two chhatris on top, with slender pillars but similar domes. The tomb is of the common Gujarati plan of two concentric squares, the inner one filled with fine geometrical screens which do something to relieve the mediocrity of the group as a whole.

More pleasing to the eye are the mosque and tomb of Shuja'at Khān, viceroy, 1096-1113/1685-1701, where the mosque carries an inscription of 1006/1695-6 (the date of completion, as Shuja'at Khān died in 1113/1701). Here the five-bayed façade of the mosque has the bases carrying the pseudo-minarets between bays one and two, four and five, rather than at the ends, the prayer chamber has three shallow domes, only slightly bulbous, resembling those over the tombs of Atga Khān in Delhi, with a polychrome band of merlon shapes on the drum below the swelling of the dome, and the wide piers flanking the central arch bear small blind cusped arches; the walls were of marble below and finely polished chunam above, and the floor of white and yellow marble in the pattern of musallās, or compartments resembling prayermats for individual worshippers. The tomb, on an adjacent platform, is a square structure with an arcade around the tomb chamber, without the characteristic Gujarati screens, covered with a similar dome. The mosque (in a courtyard surrounded by arcuate rooms which once formed a madrasa) of Hidāyat Bakhsh, c. 1110/1699, is again of five bays, separated only be slender piers, more modest pseudo-minarets at the ends of the façade, and with three shallow domes, a felicitous composition. The former madrasa has been so distorted by later settlement that its original plan is obscure.

An even more extraneous element is seen in a couple of late 18thcentury tombs near the tomb of Daryā Khān (there are a few more elsewhere in the city). These are square structures with the roof cornices 
curve downwards at every corner of the building, so that each façade presents an arched face. This is the Bengali chau-chalā roof, introduced into North India only in Shāhjahān's reign and taken over subsequently into Mughal building, whence it was largely copied in Rajasthan palaces and Sikh buildings; but the style - with such marvellous exemplars from the high dates of the Gujarat Sultanate in the architectural history of the region - seems singularly inappropriate here.

\section{BHAROCH*}

Name of the principal town of a district of the same name in Gujarat. It is first known as a town within the Maurya dominions, and later (c. 150 A.D.) to have been in the hands of Parthian Săhas; from the Middle Indian form bharugaccha - of the Sanskrit bhrguksetra - it was known to the Greeks as $\beta \alpha \rho v \gamma \alpha \zeta \alpha$, a seaport from which the Red Sea commerce carried on (Ptolmey, Geog. VII, i, 63; VIII, xxvi, 12), and as the head of an important trade-route into India (Periplus, 47-8). Held by Rājputs and Gurjaras, probably as tributaries of the Chālukyas, it suffered Arab invasions in 15/636, 99/717, and 154/770. It was held by Rāshtrakuțas in the 9th and 10th centuries until reconquered by the Chālukyas; from them it was taken in 698/1298 by Ulugh Khān, brother of the Sulțān 'Alā' al-Dīn Khaljī, by whom Hindu and Jain temples were destroyed (Briggs, Ferishta, i, 327). It was under a succession of Muslim governors representing the Delhi sultāns until 798/1396, when Muhammad Zafar Khān (governor from 793/1391) assumed his independence. From then it continued subject to the Ahmad Shāhī kings until annexed by Akbar in 980/1572. In 1149/1736 'Abd Allāh Beg received from Nizāam al-Mulk (independent in the Deccan from $1135 / 1722$, who previously as governor of Gujarat had made Bharoch part of his private estate) the title of Nīq 'Âlam Khān, and was the founder of the line of Nawwābs of Bharoch. In 1186/1772 Bharoch was captured by the British - whence its Anglo-Indian name of Broach.

* "Bharoč," EI, I, 1193. 


\section{Monuments}

The old fortification were rebuilt by Bahādur Shāh (932-43/1526-37). In 1071/1660 they were partially razed by Aurangzīb, but rebuilt on his orders in 1097/1685 as a protection against the Marāthās. They are now in a very dilapidated condition. The Jāmi' Masjid, c. 701/1302, is of great significance in the development of Islamic architecture in Gujarat: the earliest buildings at Patan were mere adaptations of existing Hindu and Jain structures, whereas here an original and conventionally planned mosque is composed of former temple materials, the enclosure walls, of temple stones specially recut, being thus the earliest examples of independent Islamic masonry in Gujarat. The tiveran is an open colonnade, the three compartments of which are three temple mandapas reerected intact, except for the removal of the Hindu animal figures, with 48 elaborately carved pillars; the three mihrābs are intact temple niches with pointed arches added under the lintels. The liw $w \bar{a} n$ roof, with three large and ten small domes, houses elaborate coffered ceilings removed from temples; the designs of these, though Hindu, were conventional in character, and were perpetuated in later Gujarati Islamic buildings. It appears that the whole production was the work of local Hindu artisans working under the direction of Muslim overseers.

\section{BIDAR*}

The identification of Bidar with the ancient Vidarbha (Briggs's Ferishta, ii, 411) is now discounted (cf. G. Yazdani, Bidar..., Oxford 1947, 3). Bidar was included in the Chālukya kingdom of Kalyani, 10th-12th centuries, but was in the hands of the Kākatīyās of Warangal when conquered by Ulugh Khān (later Muhammad b. Tughluq) in 722/1322 (details of siege and mention of fortifications, Diyầ al-Dīn Baranī, Tả̄knh-i Fìnūz Shāhī, Bibl. Ind., 449), from whose governor it was taken after a fierce battle in $748 / 1347$ by a Amìr-i Sadah (commander of a șadi or subdivision of approximately 100 villages; Baran̄i, 495; Rihla, Cairo ed., ii, 75), Zafar Khān. The latter, on his acceptance as first king of the Bahmanī dynasty as 'Alā' al-Dīn Ḥasan Bahman Shāh, divided his

* "Bahmanīs, Monuments," EI, I, 926-5; "Barīd Shāhīs, II. Monuments," EI, I, 1047-8; "Bīdar," EI, I, 1199-1201; historical section co-authored with H.K. Sherwani. 
dominion into four provinces, of which Bidar was one. The town was important strategically, and as a fortress held the seventh Bahmanī king Shams Dīn (799/1397) in internment; Muhammad II (780-99/137897) established orphanage schools in Bidar and elsewhere, $c f$. Briggs's Ferishta, ii, 349-50. An assault by the eighth king, Fīrūz Shāh, against his brother Ahmad in 825/1422 was repulsed at Bidar, leading to Ahmad's succession, shortly after which he transferred his capital to Bidar from Gulbarga (Sayyid 'Alī TTabațabā, Burhān-i Ma'āthir, Hyderabad edn., 49-50), rebuilt the fortifications and renamed it Muhammadabad; the natural position of Bidar on a healthy plateau with abundant water, and its central position in the kingdom, offered advantages not possessed by Ahsanabad-Gulbarga. Bidar was attacked in $866 / 1462$ by Sulțān Mahmmūd Khaljī of Malwa, who destroyed some of its buildings, but was repulsed with the aid of Sulțān Mạ̣mūd Shāh of Gujarat. Bidar's heyday under the Bahmanīs was during the able ministry of Mahmūd Gāwān, c. 866-886/1462-81; but after his murder the Bahmanī power declined, to the advantage of the minister Qāsim Barīd (founder of the Barīdī dynasty) and his family. The Bahmanīs remained as puppet kings under the Barīdī ministers until at least 952/1545; Amīr Barīd was de facto ruler until 949/1542, and his son 'Alī Barīd adopted the royal title, presumably after the death of the last Bahmanī king, Kalīm Allāh (for coins in whose name, dated 952/1545, see Proc. VII All-India Oriental Conf., 740). Bidar fell to Ibrāhīm 'Ādil Shāh of Bijapur in 1028/1619, was annexed to the Mughal empire by Aurangzìb in 1066/1656, and passed to Nizāām al-Mulk Āṣaf Jāh in 1137/1724.

\section{Bahmañ̄ Monuments}

The city and fort are both fully walled, and in their present area date from the time of Ahmad Shāh Walī Bahmanī, who incorporated the old Hindu fort in the west of the present area into his buildings of 832-5/1429-32; Persian and Turkish engineers and architects are known to have been employed. The ground on the north and east of the perimeter falls sharply away; on the other sides the walls are within a triple moat hewn out of the laterite outcrop by local Hindu masons (Yazdani, op. cit., p. 29). Much of the defences was destroyed in Maḥmūd Khalj̄̄’s invasion and restored by Niẓām Shāh; but their character was changed in the time of Muhammad Shāh Bahmanī, c. 875/1470, after the introduction of gunpowder. Minor improvements were made by Mạ̣mūd Shāh (inscriptions, EIM 1925-6, 17-8), and 
more extensive ones, including the mounting of large guns, by 'Alī Barīd Shāh, 949-87/1542-79. The description of the defences in the reign of Shāhjahān by Muḥammad Șālị̣ Kambō ('Amal-i Șālih, Bibl. Ind. iii, 249-50) indicates that little subsequent changes were made. In the perimeter of $4 \mathrm{~km}$. there are 37 bastions, mostly massive, many with gun emplacements, and seven gates as well as the three successive gates between town and fort. The first gateway serves as a barbican for the second, the Sharza Darwāza - so called from the figures of two tigers carved on the façade, a common feature of Deccan forts (Yazdani, op. cit., 32). The third gate, Gunbad Darwāza, is massive, with battered walls, hemispherical dome and corner guldastas recalling the contemporary Delhi architecture, but with an outer arch of wide span stilted above the haunch, the shape of much Persian-inspired architecture in the Deccan and characteristic of the Bahmani buildings in particular (Yazdani, op. cit., 34). The town walls are said to be the work of 'Alī Barīd (Muḥammad Sultān, Ā ̀̀na-i Bìdar, 17-18) in 962-5/1555-8, but doubtless superseded Bahmanī work. Again there are 37 bastions, adapted for long-range guns, and five gateways (Yazdani, op. cit., 83-90).

Within the fort are the Solah Khambā ('sixteen pillar', so called from a period of its decay when sixteen pillars were screened off in the $\bar{\imath}(\bar{a} \bar{a})$ Masjid, the earliest Muslim building at Bidar and the original Jāmi` Masjid, having been established before the transfer of the capital (inscription giving date 827/1423-4, EIM, 1931-2, 26-7); the style is heavy and monotonous, particularly in the $91 \mathrm{~m}$. long façade, and the inner circular piers are over-massive; the central dome rests on a hexadecagonal collar pierced with traceried windows, to form a clerestory (Yazdani, op. cit., 54-6); the Takht Mahall, the modern name for what was probably Aḥmad Shāh Walī Bahmanī’s palace described in the Burhān-i Ma'äthir, 70-1, and referred to as dār al-Imāra by Firishta, i, 627. The arches have the typical Bahmanī stilt at the apex, and the fine encaustic tile-work, probably imported from Kashan, includes the emblem of the tiger and rising sun (Yazdani, op. cit., 66-77); the Bahmanī Dīwān-ī 'Āmm, with fine tile-work in floral, geometric and calligraphic (Kūfic) designs, generally Persian with some chinoiserie (Yazdani, op. cit., 62-6); the Gagan = [Skt. 'sky'], Tarkash and Rangīn Mahalls, all begun in Bahmanī times and rebuilt by the Barīd Shāhīs: typical Barīdī chain-and-pendant motif in Tarkash Mahall, 'Alī Barīd's rebuilding of Rangīn Mahall with inlay mother-of-pearl work and woodcarving in Hindu as well as Muslim patterns, with some cusping of wooden arches, the best of Barīdī work but on too small a scale to be fully 
effective (Yazdani, op. cit., 60-2, 57-9, 44-9 respectively); a group of underground rooms, Hazār Kotthrī, with an emergency escape passage leading outside the walls (Yazdani, op. cit., 77-8); the Shāhī Hammām, late Bahmanī or early Barīdī, with a fine vaulted ceiling (Yazdani, op. cit., 51-2); and minor buildings.

Within the town walls are the Chaubāra, a massive tower at a crossroads probably built by Aḥmad Shāh as an observation post (Yazdani, op. cit., 90); the great madrasa of Mahmū̄ Gāwān, built 877/1472, whose Persian prototype was the madrasa of Khargird in Khurasan $(c f$. E. Diez, Churasanische Baudenkmäler, i, 72-6); its remaining minār (the other, with the south-east corner, destroyed by a gunpowder explosion in 1107/1696), $40 \mathrm{~m}$. high, in three stages. Much of the former tilework has perished from the minārs and façades, but the proportions, the silhouette, and the interplay of light and shade due to the rows of deeply recessed arches on all faces are very pleasing to the eye. The most imposing monument of the Bahmani period, it has no parallel elsewhere in India (Yazdani, op. cit., 91-100); the Takht-i Kirmān̄̄, a gateway containing a room in which is a couch associated with the saint Khalī Allāh, with fine cut-plaster medallions, etc., of late Bahmanī design, and a trefoil parapet which, originating in the Bahman̄ period, is found in Barīdì buildings also (Yazdani, op. cit., 100-2); the Jāmi' Masjid of the city, plain but elegant, with a high lantern-vaulted lìwān under its double dome, late Bahmanī work restored in the Barīdī period (chain-and-pendant motif in spandrels of façade; Yazdani, op. cit., 103-4); the Bari Khānqāh of Maḥbūb Subḥānī, whose mosque parapet shows the overlapping arches of the Bahmani period (Yazdani, op. cit., 111). Outside the town walls are (besides the tomb buildings of the Bahman̄̄s and Barīd Shāhīs) the fine Chaukhandī of Hazrat Khalìl Allāh, similar in style to the tomb of 'Alä' al-Dīn Bahmanī and one of the best Bahmanī buildings (Yazdani, op. cit., 141-6); the tombs of the Abyssinian nobles in the Habshī Kōt (Yazdani, op. cit. 180); the Kālī ('black') Māsjid, probably early Barīdī, whose mihrāa, projecting out from the liwa an, forms a high square chimney-like base for a dome supported on each side by an open arch, resembling an aerial Barīdī tomb (Yazdani, op. cit., 196-7); and numerous other buildings.

The Bahmanī tombs at Ashtur, $2.5 \mathrm{~km}$. east of the town, are on a large scale, with lofty and sometimes bulbous domes. None of these has battered walls, and none is double, as at Gulbarga. The finest tomb, that of Ahmad Shāh Walī (d. 839/1436), shows the characteristic later Bahmanī arch, stilted above the haunch, and is of great importance 
on account of its superb calligraphic decoration which includes two shajrās of the saint Ni'mat Allāh al-Kirmānī. That of 'Alā' al-Dīn II (d. 862/1458) has striking encaustic tile-work and, unusually, some arches struck from four centres. That of Mahmūd (d. 924/1518) has its walls decorated with arched niches one above the other, more characteristic of post-Bahmanī architecture.

\section{Barìd̄̄ Monuments}

As successors to the well established Bahmanī dynasty the Barīd Shāhīs inherited many fine structures, and their building activity in Bidar was more a matter of adaption and rebuilding than of the erection of any major stuctures. The progress of the Barīdī style is well illustrated in their tombs, which form a royal necropolis some $3 \mathrm{~km}$. west of the city walls, and occupy a large area on account of the vast garden enclosures of each tomb.

The tomb of Qāsim I (d. 910/1504) is a small insignificant building with a plain cubical dome (Yazdani, op. cit., 149). That of his successor, Amīr Barīd I, was left incomplete on his sudden death in 959/1542 without a dome; there are two storeys of arches on each façade, pierced by a central arch running through both storeys, all stilted at the apex as in the earlier Bahmanī buildings. The reign of 'Alī Barīd (949-87/1542-79) saw much building activity; large scale improvements in fort and city fortications, including the mounting of many more large guns; rebuilding the Rangin Mahal, with fine mother-of-pearl inlay work and intricate wood-carving to which Hindu patterns are mixed with Muslim designs (Yazdani, op. cit., 44-9); much alteration of the Tarkash Mahall, especially the upper storey, in which the chain-and-pendant motif, characteristic of Barīdī work from now on, is apparent (Yazdani, op. cit., 57-9); and tomb of 'Alī (d. 987/1579), very well sited, with an imposing gateway having wide arches with low imposts and upper rooms decorated with a profusion of small cusped niches. Each wall of the tomb consists of one open arch, through which the fine sarcophagus of polished black basalt is visible; the interior is thus very bright and airy, and is embellished with good encaustic tile work (verses from 'Atțāar, Qur'ānic texts, in thulth), though not over-elaborated. Since the tomb is open on all sides there is no qibla enclosure, and attached to the tomb there is a separate mosque with slender minarets, a vaulted ceiling, and fine cutplaster decoration on the façade. Tomb, gateway and mosque have the trefoil parapet which originates in the late Bahmanī period (Yazdani, 
op. cit., 151-60). The tomb of Ibrahīm (d. 994/1586) imitates that of his father on a smaller scale but is incomplete and presents surfaces of lime-laid masonry. Carved corner jambs show the Hindu chakra as part of their decoration (Yazdani, op. cit., 160-1). Both these tombs have a large dome, not stilted but recurved at the base to form a three-quarter orb, which appears somewhat top-heavy for the structure. The constriction of the dome is characteristic of the contemporary buildings of the Qutb Shāhī and 'Ādil Shāhī dynasties of Golkonda and Bijapur also. The single opening is reverted to in the tomb of Qãsim II, which is better proportioned, but the open design is apparent in the dome over the mihrāb of the Kālī ('black') Masjid (Yazdani, op. cit., 196-7). The Jāmi' Masjid of the town, a late Bahmanī building, was restored during the Barīdī period (chain-and-pendant motif in spandrels of the façade) (Yazdani, op. cit., 103-4).

From the time of 'Alī Barīd the buildings become more ornate in their minor detail, and the influence of the Hindu mason becomes more apparent; in some Barīdī buildings - e.g., the Kālī Masjid - the forms used in stone often seem more appropriate to wood-work. Much of the later work shows that meretricious character often apparent in the buildings of a dynasty in decline.

\section{BIHAR*}

A province of India, bounded by Uttar Pradesh on the west, Nepal on the north, West Bengal on the east and Orissa on the south, taking its name from the now unimportant town of Bihar, surrounded by Buddhist monasteries (Skt. vihära). Bihar was in the British period from 1765 within the Lieutenant-Governorship of Bengal, later joined administratively with the now independent Orissa. This lack of independence reflects the position of the region from the earliest days of Islamic supremacy in India, and its history is one of individual governors and towns rather than of dynasties and regions. Monghyr (Mungīr), for example, was taken during Ikhtiyār al-Dīn Muhammad b. Bakhtiyār Khaljī's raids on Bihar in 589/1193 and held by him under the Delhi sulțān Quṭb al-Dīn Aybak; it was annexed to Delhi by Muhammad b. Tughluq in 730/1330, belonged to Jaunpur from 799/1397, reverted to

\footnotetext{
* "Bihār," EI, I, 1209-10.
} 
Delhi when overrun by Sikandar Lōdī in 893/1488, and was later held by the kings of Bengal before becoming subject to the Mughals. Parts of Bihar did form a separate administrative unit in the 13th century (Shams Dīn Iletmish established a governor in Bihar in 622/1225); under Akbar in 990/1582 it formed a sūba or eight sarkārs, subordinate to the süba of Bengal. The capital remained at the town of Bihar until transferred to Patna by Shēr Shāh Sūrī in the early 16th century. The importance of the region was as a buffer between Awadh and Bengal until the Mughal period, when the emphasis was as a line of communication between them, as many fine bridges of the Mughal viceroys testify.

\section{Monuments}

There is no particular 'Bihari' style of Indo-Islamic architecture. The finest group of buildings is at Sasaram, including the justly famous mausoleum of Shēr Shāh (inscription of 952/1545) standing $50 \mathrm{~m}$. high in a large artificial lake; its architect, Aliwāl Khān, had been a master-builder under the Delhi Lōdīs, but his treatment of the octagonal mausoleum transcends any of the Lōdī conceptions. Shēr Shāh obtained the fort of Rohtasgarh from its Hindu rāja in 946/1539, and to him is attributed the Jāmi 'Masjid; the reconstructed fortifications, the palaces, Habash Khān's tomb and mosque, etc., date from the viceregency (988-1008/1580-1600) of Rājā Mān Singh under Akbar; to Mān Singh is attributed the mosque at Hadaf, near Rajmahal; the long barrel-vault traversing the central bay of the tiw wan of this early Muhgal structure recalls the style of Jaunpur. Monghyr has been mentioned above: the fort is reputed to have been built by early Bengal kings, but the style appears Mughal; Rājā Todar Mall is known to have repaired the fortifications in 988/1580. The two forts of Palamav, built by local Chero Rājās in the 17th century, were taken by the Mughal governor Dāūd Khān Kurayshī, who erected a mosque (1070/1660) and other structures; the Nayā Qil'a boasts the splendid Nāgpurī Darwāza in the Jahāngīrī style. The tomb of Makhdūm Shāh Daulat (Chōtī Dargāh) at Maner erected by the governor Ibrāhīm Khān in 1017-26/1608-16 is of some merit. For other buildings see M.H. Quraishi, List of ancient monuments... in Bihar and Orissa, ASI NS, ii, Calcutta 1931. 


\section{BIJAPUR*}

\section{History}

Town and headquarters of the district of the same name in northern Karnataka. It was the seat of the Yādavā kings for over a century from $586 / 1190$ to 694/1294 when it was conquered by 'Alā' al-Dīn Khaljī for his uncle Jalāl al-Dīn Khaljī, king of Delhi. In 890/1485-6 Yūsuf, an alleged son of the Ottoman sultān, Murād II who, on the accession of his brother Mehmed II to the throne, was said to have escaped certain death through a stratagem of his mother, founded the Muslim kingdom of Bijapur and built the citadel. This story seems to be unknown to the Ottoman historians (cf. Khalil Edhem, Düwel-i Islämiyye, 495); the Ottoman historian Munajjim Bashi, who includes an account of the 'Ádil Shāhīs in his fāmi al-Duwal, describes Yūsuf as of Turcoman origin. For a discussion of this question see further Ismail Hikmet Ertaylan, Adilsâhîler, Istanbul 1953, 3 ff.). He also captured Goa and included it in his dominions. He assumed the title of 'Âdil Shāh which became the royal surname and the dynasty came to be known as the 'Ádil Shāhīs of Bijapur. He was succeeded by three incapable or profligate rulers. In 965/1557 'Alī 'Ádil Shāh came to the throne; he built the city wall of Bijapur, the Jāmi' Masjid, aqueducts and other public utility works. In 973/1565 the combined troops of Bijapur, Ahmadnagar and Golkonda defeated the Vijayanagara forces at the so-called battle of Talikota. 'Alī 'Ādil Shāh died in 987/1579 and was succeeded by his minor nephew Ibrāhīm 'Âdil Shāh, under the regency of the famous Chand Bībī. He died in 1036/1626 after an independent rule of 47 years and was succeeded by Muhammad 'Ādil Shāh, during whose reign, Shivājī, the Marāthā leader rose to power. His father Shāhjī Bhōnslē was a petty officer of the Bijapur sultān. Having been bred and brought up on Bijapur 'salt', Shivājī repaid the debt of gratitude by attacking Bijapur territory and between 1056/1646 and 1058/1648 he seized many forts of importance. In 1067/1656-7 Aurangzīb, while still a prince, attacked and beseiged Bijapur but on hearing of the serious illness of Shāhjahān had to lift the siege and leave for Agra. Thirty years later (1097/1686) Aurangzīb succeeded in subduing Bijapur during the reign

* "Bīdjāpur" EI, I, 1203-4; history section co-authored with A.S. Bazmee Ansari. 
of Sikandar 'Adīl Shāh (1083/1672-1097/1686), the last of the 'Adīl Shāhs. Sikandar 'Ādil Shāh was imprisoned and allowed a pension by Aurangzīb. He died in 1111/1699-1700. In 1100/1688 Bijapur was visited by a virulent type of bubonic plague which claimed 150,000 persons, including Aurangābādī Mahall, a queen of Aurangzīb, while Ghāzì Dīn Fìrūz Jang, a high noble, lost an eye. Towards the close of his reign Aurangzīb appointed his youngest son, Kām Bakhsh, to the government of Bijapur. On Aurangzīb's death Kām Bakhsh proclaimed himself emperor at Bijapur, assuming the title of Din-Panāh. In 1137/1724 Bijapur was included in the dominions of the Nizām of Hyderabad. It was, however, transferred to the Marāthās in 1174/1760 for a sum of 6,000,000 rupees. On the overthrow of the Pēshwā in 1234/1818 the British occupied Bijapur and assigned it to the Rājā of Satara in whose possession it remained till 1266/1848 when, on the lapse of the State, it formed part of British Indian territory. In 1281/1864 Bijapur was made a separate district and in many of the old palaces were housed government offices which were, however, later shifted elsewhere.

The 'Ādil Shāhīs were great patrons of art and literature. Malik Qummī, the poet, and Zuhūri, the celebrated author of the two Persian classics, Sih Nathr and Min̄a Bazār, adorned for a considerable time the court of Ibrāhīm 'Ādil Shāh, himself a poet, who composed in Dakhnī Urdu.

\section{Monuments}

The 'Âdil Shāhīs developed the building art above all others, and their architecture is the most satisfactory of all the Deccan styles, both structurally and aesthetically; hence their capital Bijapur shows a more profuse display of excellent and significant buildings than any other city in India except Delhi alone. The Bijapur style is coherent within itself, and there is a gradual progression between its two main phases. Most worthy of note are the doming system with its striking treatment of pendentives; profuse employment of minarets and guldastas as ornamental features, especially in the earlier phase; elaborate cornices; reliance on mortar of great strength and durability. The materials employed are either rubble-and-plaster or masonry; the stone used in masonry work is a local, very brittle trap. There is evidence to show that architects were imported from North India, and that use was freely made of local Hindu craftsmanship. 
Pre-'Ádil Shāhī works are few: the rough mīnārs with wooden galleries in the walling of the Makka Masjid; Karīm al-Dīn's mosque, inscr. 720/1320, from pillars of old Hindu temples, trabeate, with elevated central portion as clerestory, recalling the mosques of Gujarat; the Bahmanī Wāzīr Khwāja Jahān's mosque, c. 890/1485, similar but without clerestory.

No 'Ādil Shāhī building can be certainly assigned to the reign of Yūsuf. The earliest dated structure, referred to as Yūsuf's Jāmi' Masjid, strikingly foreshadows the style to come with single hemispherical dome on tall circular drum with the base surrounded by a ring of vertical foliations so that the whole dome resembles a bud surrounded by petals, and façade arches struck from two centres, the curves stopping some way from the crown and continued to the apex by tangents to the curve; an inscription of 918/1512-3 records its erection by Khwāja Sanbal in the reign of Sulțān Mạ̣mūd Shāh, son of Muhammad Shāh Bahman̄i, indicating that Bahmanī suzerainty was still acknowledged some time after the 'Ādil Shāhī defection. Of Ibrāhīm's reign are also the massive Dakhnī '̄ Igāh (within the present city walls) and several small mosques, on one of which (Īkhlāṣ Khān's) the arch spandrels are filled with medallions supported by a bracket-shaped device, later a very common ornament. Only one mosque of this period (at Ibrāhīmpur, $932 / 1526)$ is domed.

The long reign of 'Alī I saw much building activity: the city walls, uneven in quality since each noble was responsible for a section, completed 973/1565, with five main gates flanked by bastions and machicolated, approached by drawbridges across a moat, beyond which is a revetted counterscarp and covert way (many bastions modified to take heavy guns; inscriptions of Muhammad and 'Alī II); the Gagan ('sky') Mahall, an assembly hall with much work in carved wood; a mosque in memory of sayyid 'Alī Shāhīd Pīr, small (10.8 m. square) but superbly decorated with cut-plaster, with a steep wagon-vaulted roof parallel to the façade, a tall narrow chimney-like vault over the mihräb which has a door leading outside; the Shāhpur suburb; outside Bijapur, the forts of Shahdrug (966/1558), Dharwar (975/1567), Shahanur and Bankapur (981/1573); 'Alī's own severely plain tomb; and his Jāmic Masjid, generally ascribed to $985 / 1576$, a fine large (137.2 by $82.3 \mathrm{~m}$.) building, not fully completed (only buttresses where tall minārs were to be added, no kanguras over façade), sparingly ornamented (only the central arch of seven in the tiw wan façade is cusped and decorated with medallion-and-bracket spandrels), with the great hemispherical dome, 
standing on a square triforium, capped by the crescent, a symbol used by the 'Âdil Shāhīs alone among the Deccani dynasties. The cornice is an improvement on earlier works by showing deeper brackets over each pier instead of a row of uniform size. The vaulting system of the dome depends on cross-arching: two intersecting squares of arches run across the hall between the piers under the dome, meeting to form an octagonal space over which the dome rests; the pendentives thus overhang the hall and counteract any side-thrust of the dome. The exterior walls are relieved by a ground-floor course of blind arches over which is a loggia of open arches.

In Ibrāhīm II's reign fine sculptured stonework replaces the earlier rubble-and-plaster. The palace complex dates from about 990/1582 (Sāt Manzil, 'Granary', Chīnī Mahall); the first building in eleborate sculptured stone is Malika Jahān's mosque (994/1586-7), which introduces a new shape by the dome forming three quarters of a sphere above its band of foliation. The Bukhārī mosque and three others on the Shāhpur suburb are very similar, and fine stonework occurs also in perhaps the greatest work of the 'Ādil Shāhīs, the mausoleum of Ibrāhīm II and his family known as the Ibrāhīm Rauza: within a garden enclosure $137.2 \mathrm{~m}$. square stand a tomb and mosque on a common plinth; the tomb (shown by inscriptions to have been intended for the queen Tāj Sultāna only) has uneven spacing of the columns and other features, and the cenotaph chamber is covered with geometric and calligraphic designs, reputedly the entire text of the Qur'ann. The mosque columns are regular. The whole composition is in perfect balance and was minutely planned before building. An inscription gives the date of completion, by abjad, as 1036/1626. Palaces of this reign include the Ānand Mahall, built for entertainments (Basātīn al-Salāțin), and the Āthār Mahall (1000/1591) with fine painted wood decoration including some fresco figure-paintings thought to be the work of Italian artists. The Andā ('egg') Masjid, 1017/1608, has the mosque (presumably for the use of women) on the upper storey, with a sara $\bar{\imath}$ below; the masonry is polished and finely jointed, and above is a ribbed dome. In 1008/1599 Ibrāhīm proposed moving his seat of government some $5 \mathrm{~km}$. west of Bijapur where the water supply was better; but the new town, Nauraspur, was sacked in 1034/1624, before its completion, by Malik 'Ambar, and little remains. Other work includes the mosque known as the Nau Gunbad, the only Bijapur building with multiple doming; the fine but incomplete mausoleum of the brother pirs Hamīd and Lațif Allāh Kāàirī (ob. 1011/1602, 1021/1612); and, the supreme example 
of the later work of this reign, the Mihtar-i Mahall, really a gateway to the inner courtyard of a mosque in the city, with a narrow façade based on a vertical double square, richly covered with stone diaper patterns and with a balcony supported by long struts of carved stone, their decoration resembling, and really more appropriate to, woodwork patterns; fine panelled ceilings within; superb cornices and elaborate minārs, outside, all richly carved.

Works of Muhammad's reign are of uncertain chronology owing to lack of inscriptions and historical records. Muṣafā Khān's mosque is plain with a façade in which the central arch is much wider than the flanking ones, following the pattern of many of the older palaces; his sarā $\bar{\imath}$ (insc. 1050/1640-1); a mahall at Aynapur; tombs of the wazir Nawāz Khān (ob. 1058/1647) and of several pìrs showing a decadence in style with a second storey and dome too attenuated for the size of the buildings; Afẓal Khān's mausoleum and mosque, where the second storey is of insufficient height - the mosque being the only two-storeyed one in Bijapur, the upper tiwe $\bar{a} n$ being the duplicate of the lower except for the absence of a minbar, hence presumably for Afẓal Khān's zanāna, 63 members of which have their reputed graves $1 \mathrm{~km}$. to the south: inscription in mausoleum 1064/1653; and the major building work, one of the supreme structural triumphs of Muslim building anywhere, Muhammad's own mausoleum, the Gol Gunbad. The tomb building, standing within a mausoleum complex, is formally simple: a hemispherical dome, of $43.9 \mathrm{~m}$. external diameter, is supported on an almost cubical mass $47.4 \mathrm{~m}$. square (external), with a staged octagonal turret at each angle. The floor area covered, about 1,693 sq. m., is the largest in the world covered by a single dome. External decoration is simple, confined to the great cornice $3.5 \mathrm{~m}$. wide supported by four courses of brackets, the openings on the pagoda-like corner turrets, and the merlons and minarrs of the skyline. The dome is supported internally by arches in intersecting squares as in the Jāmi 'Masjid; inscription over the south door gives the date of Muhammad's death by abjad as $1067 / 1656$ at which time work on the building presumably stopped, the plastering being incomplete. Unfinished also is the tomb of his queen Jahān Bēgam at Aynapur: foundations, piers and octagon turrets to the identical scale of the Gol Gunbad, but the dome was intended to be carried across a central chamber.

Of 'Alī II's reign: the pavilion called Pānī Mahall on the citadel wall, and the Makka Masjid, both with fine masonry and exquisite surface carving; the tomb-complex of Yāqūt Dābulī, unusual by having the 
mosque larger than the tomb; and 'Alì's own unfinished mausoleum, with arches struck from four centres instead of the usual Bijapur arch. Later buildings are insignificant, except for Aurangzīb's eastern gate to the Jāmi' Masjid; the tomb of the last monarch, the minor Sikandar, closes the 'Ādil Shāhī effort with a simple grave in the open air.

\section{Champaner*}

A ruined city of Gujarat in Western India, about $125 \mathrm{~km}$. south-east of Ahmadabad, taken by the Gujarat sulțān Mahmūd Shāh I 'Begrā' on his conquest (889/1484) of the adjoining stronghold of Pawagarh, which had successfully resisted Ahmad Shāh I in 821/1418. The 'Begrā' occupied Champaner forthwith, building a city wall with bastions and gates (called Jahānpanāh; inscription EIM 1929-30, 4-5), and a citadel (bhädar). He renamed the city Mahmudabad, and it was his favourite residence until his death in 917/1511; it remained the political capital of Gujarat until the death of Bahādur Shāh in 942/1536. When Gujarat came under the Mughals after 980/1572 Champaner was the head of a sarkār of 9 mahals (Jarrett, $\bar{A} i n$-i Akbarī, ii, 256; of 13 divisions, according to the Mir'ät-i Sikandarì); it fell to the Marāthās at the end of the 18th century, and came into British hands in 1853; almost deserted, it was not recolonized.

\section{Monuments}

Of Maḥmūd's seven-storeyed palace (Sāt Manzil) built in steps on the cliff edge opposite Pawagarh only the lowest storey remains; the other monuments other than the walls (cf. Bombay Gazetteer, iii, 307-8) are all mosques and tombs, which in their similarity exhibit a local style. The Jāmi 'Masjid, c. 929/1523, is inspired in plan by that of Ahmadabad, 100 years older; but here there is a double clerestory in the liw $w \bar{a}$ in the space of one dome only; the arcuate maqșura screen and the trabeate hypostyle liwe arn are well integrated; the side wings of the līwān are proportioned as a double square ( 8.5 by $17.0 \mathrm{~m}$.); a zanāna enclosure is formed by screening off the northernmost mihrāb; and the external surfaces, as in all the Champaner buildings, are the subject

* “Čāmpānēre” EI, II, 10-11. 
of rich plastic decoration - particularly the buttresses supporting each of the seven sumptuous mihräbs. The other buildings - ten mosques, many nameless tombs - are of similar style, characterized by refinement of decoration; the niches in the minārs of the Nagīnā Masjid are of an exquisite marble tracery excelled only by that of Sidī Sa î̀d's mosque in Ahmadabad. The tombs use the arch more freely than the mosques, and their carved decoration is of consummate delicacy, skill and craftsmanship.

\section{ChANDERI*}

A town and old fort in north-central India, on a tableland overlooking the Betwa valley on the east. Early references by al-Bīrūnī (421/1030) and Ibn Bațtutata do not mention the fort and probably relate to a site some $15 \mathrm{~km}$. north-north-west known now as Burhi [Urdū, 'old'] Chanderi; here there are ruined Islamic fortifications among Hindu and Jain remains, probably of the early 14th century, for although the city fell in 649/1251 to Ghiyāth al-Dīn Balban, then $n \bar{a}$ ì of Nāṣir al-Dīn, whose aim was the seizure of booty and captives, it did not come into Muslim hands until 'Ayn al-Mulk's defeat of the Rājā Harānand in 705/1305. Four years later it formed the rendezvous for Malik Kāfūr's force before his march on Warangal in Telingana. New Chanderi seems to have been built by the Ghūrī kings of Malwa in the early 15th century (inscriptions of Dilāwar Khān and Hūshang, in ASI AR, 1928-9, 128, and EIM 1943, 47), from whom it was wrested in the Malwa interramal struggles by 'Alā' al-Dīn Shāh Khaljī I in 842/1438 (Bayley's History of Gujarat [Ta'rikh-i Alfi] ], 123), and remained under the Khaljīs' governors until the vacillating governor Bahjat Khān revolted, supporting against Mahmūd II his brother Șāhị Khān, the puppet Muhammad II, and appealing to Sikandar Lōdī of Dehli for support in 919/1513. Hereafter Chanderi's position on the borders of Bundelkhand and Malwa led to its changing hands frequently: Sikandar's forces remained in occupation until 921/1515, but after their withdrawal it was seized by the Rānā of Chittaur who set up Medin̄̄ Rāy, Mahmmūd II's dismissed minister who had escaped the massacre at Mandu, as governor; from him it was taken by Bābur in 934/1528,

\footnotetext{
* “Čandērī," EI, II, 12-13.
} 
who restored it to Ahmad Khān, son of Șāhib Khān. Later it fell to the Pūrbīya Rājput Pūran Mal, who lost it to Shēr Shāh c. 947/1540, but later retook it and massacred and degraded the Chanderi Muslims, an act which brought retribution from Shēr Shāh in 950/1543 (Brigg's Ferishta, ii, 160). After Akbar had gained the süba of Malwa, Chanderi became the headquarters of a sarkār ( $\bar{A} \hat{\imath} n-i$ Akbari, i, 122), when it was said to have been a large city with 14,000 stone houses and over 1,200 mosques. Thereafter it passed frequently into Bundel hands, and after the early 18th century remained in Hindu possession.

\section{Monuments}

The city is walled, with five gates, one of which is the Kātīghātī hewn through the rock outcrop; the fort, which stands some $70 \mathrm{~m}$. higher, is dependent for its water supply on a large tank at the foot of the hill, access to which is by a covered way (map in Cunningham, ASI, ii, Pl. XCIII). The Jāmi' Masjid is similar to that of Mandu with its tall domes over the tiw wan stilted between springing and haunch, but with the cornice supported by a row of serpentine brackets, a contribution of Gujarat workmen; two tombs known as the madrasa and the Shāhzādī kā Rauza are of excellent workmanship in a similar style; probably somewhat earlier is the Kūshk Mahall, a large square building with intersecting passages on each of the remaining four storeys which divide the interior into four quadrants, in the suburb of Fatehabad, $3 \mathrm{~km}$. west, identified with the seven-storeyed palace (sāt manzil) whose building was ordered by Maḥmūd Shāh I in 849/1445. At the western foot of the fort is an unattached gateway, the Bādal Mahall Darwāza, a triumphal arch between two tapering buttresses, somewhat over ornamented.

\section{Daulatabad*}

\section{History}

This hill fort, $16 \mathrm{~km}$. north-west of Aurangabad in Maharashtra State, was called Deogiri (properly Devagiri), 'Hill of God', in pre-Muslim times as the capital of the Yādavas, originally feudatories of the Chālukyas

\footnotetext{
* "Dawlatābād," EI, II, 179-80; history section co-authored with H.K. Sherwani.
} 
but independent since 1183 A.D., after which they continued to rule the territory from Deogiri independently. 'Alā' al-Dīn, nephew of Sulțān Jalāl Dīn Fīrūz Khaljī of Delhi, actuated by reports of the immense wealth of Deogiri, reached there by forced marches in 693/1294 and invested the fortress. Rāmchandra, the then $r \bar{a} j \bar{a}$, taken by surprise, was ultimately forced to surrender to the invaders huge quantities of gold, silver and precious stones, which became 'Alā' al-Dīn's bait to lure Fìrūz to his death, as well as agree to the cession of Elichpur to the Delhi empire. Rāmchandra failed to remit the revenues of Elichpur and in 706/1307 a force commanded by Kāfūr Hazārdīnārī, then Malik Nā̀ib, was sent against him; but on making his submission to Kāfūr he was courteously sent to the capital where he offered sumptuous gifts in lieu of tribute. His ready pardon and official appointment as governor of Deogiri, with the title of Rāy-i Rāyan, has been attributed to 'Alā alDīn's superstitious regard for Deogiri as the talisman of his wealth and power. But his son and successor, Shankara, defied the Delhi hegemony, and Kāfür was again sent south in 713/1313, where he assumed the government of the state having put Shankara to death. Shankara's sonin-law Harapāla proclaimed his independence some three years later, and the new Delhi sulțān, Quṭb al-Dīn Mubārak Khaljī, personally led an expedition south, slew Harapāla, re-annexed the Deogiri lands, and built in 718/1318 the great Jāmi` Masjid there.

The next important date in the history of Deogiri was when Muhammad b. Tughluq decided in 727/1327 that, since Delhi was not sufficiently central in his dominions, Deogiri should be renamed Daulatabad and become his capital. Officials were at first encouraged to settle there, but in 729/1329 the entire population was compelled to move to Daulatabad as a punitive measure (Baran̄i, 481 ff; Ibn Bațtūța, iii, $314 \mathrm{ff}$ ), and from there as a base of operations order was restored in the Deccan. But shortly thereafter Mongol raids in North India necessitated Muhammad's return to Delhi and Daulatabad reverted to its status as a southern garrison. It was at Daulatabad that Ismāîl Mukh was elected their leader by the Amīrān-i Șadah in 747/1346 and it was again there that a year later Zafar Khān, who had defeated the Delhi army, superseded Ismā̄îl and became the first Bahmanī sulțān. The Bahmanīs retained Daulatabad as a garrison on their northern frontier and improved its defences; the conspicuous Chānd Mīnār dates from their occupation. It passed to the Nīzām Shāhīs of Ahmadnagar in 905/1500, becoming their capital in 1009/1600. The Mughal emperor Shāhjahān clearly considered possession of Daulatabad to be the key 
to dominion over the Deccan, and in 1043/1633 it was taken for the Mughals by Mahābat Khān after a fierce siege ('Abd al-Hamīd Lāhawrī, Bādshāh-nāma, Bibl. Ind., 496-536). Salābat Jang secured Daulatabad for the Nizāam al-Mulk in 1170/1757, but lost it three years later to the Marāthās.

Daulatabad once boasted of the Fathabad mint (for the name Fathabad given to Daulatabad in the time of Muhammad I Bahmanī, see Burhān al-Ma'äthir, 1936 ed., 17) where coin was struck from 761/1360 to $766 / 1365$; it was also the centre of a papermaking industry.

\section{Monuments}

The earliest building work at Daulatabad (apart from the rock-cut caves of the 1st century B.C.) is the scarping of Devagiri, a single conical hill of rock some $200 \mathrm{~m}$. high commanding a natural pass. This scarping, dating at least from the early Yādava times, results in the entire circuit of the rock presenting a vertical face 50 to $65 \mathrm{~m}$. high, above a water-filled moat of rectangular section dug a further $15 \mathrm{~m}$. into the rock (a causeway across the moat leading to a rock-cut shrine shows its Hindu provenance). The utilization of stone of Hindu workmanship in later Islamic building indicates the former existence of a town on the sloping ground to the east.

It is on the east that the triple apron of fortification lies, dating in origin from the time of Muhammad b. Tughluq. The outermost wall is the curtain of the outer town, which is traversed from south to north by the Aurangabad-Khuldabad road; the town (called Ambarkōt in 'Abd al-Hamīd Lāhawrī, Bādshāhnāma, passim) is an area about $2 \mathrm{~km}$. north-south by a maximum of $1 \mathrm{~km}$. east-west; the second wall encloses an area of $1.2 \mathrm{~km}$. by $0.4 \mathrm{~km}$. to the west of the first, called Katak (= Sanskrit kataka) by Ibn Bațtūța and Mahākōt (Great Fort) by Lāhaurī, and is entered through a hornwork formed by a succession of rounded bastions; a less elaborate entrance in the third apron leads to the citadel of Devagiri (Bālākōt of Lāhaurī) through a steep flight of steps, the rock-cut moat crossed by a narrow stone bridge, a tunnel through rockcut chambers and re-used Jain caves emerging some $15 \mathrm{~m}$. higher, a broad rock staircase leading to a Mughal bāradari, and finally another flight of 100 steps to the acropolis, a platform $50 \mathrm{~m}$. by $36 \mathrm{~m}$., on which guns are mounted. All three walls are defended by external ditch and counterscarp; they all show signs (by heightening in work of smaller stone) of modification during the Bahmanī period. Of interest in the 
defence works are: (1) the bridge over the final moat, with its central portion about $3 \mathrm{~m}$. below the level of each side, approached by steep flights of steps from counterscarp and gallery; the height of water in the moat must have been under control, so that the central portion of the bridge could be submerged; (2) the long tunnel, at the head of which was an iron barrier which could be rendered red-hot by lighting a fire on it (for a different interpretation see Sidney Toy, The strongholds of India, London 1957, $38 \mathrm{ff}$., criticized by J. Burton-Page in BSOAS, xxiii/3, 1960, 516 ff.); midway is a rock-cut look-out post.

The mosque of Quṭb al-Dīn Mubārak Khaljī of Delhi (inscription, 718/1318) is perhaps the earliest Muslim monument. Largely an improvization out of temple material, it has tapering fluted corner buttresses and a corbelled dome, and is some $78 \mathrm{~m}$. square in overall plan (illustration in ARADHS, 1925-6, Pl. III); the mihrāb has since been filled with an idol. The mosque has no minaret; fulfilling this function, however, is the Chānd Mīnār, $30 \mathrm{~m}$. high, of about 840/1435, similar in shape to the towers of Maḥmūd Gāwān's madrasa at Bidar, but with three galleries supported by elaborate brackets. In addition to its function as a minar of the mosque, it was also an observation post, since it commanded the dead ground on the north-east.

The palaces are mostly in ruins; noteworthy are the baradar mentioned above, built for Shāhjahān's visit in 1046/1636, and the Chīn̄ Mahall in Mahākōt, of the Niẓām Shāhī period, with fine encaustic tilework; the latter was used as a state prison for the last Quṭb Shāhī ruler, Abu'l-Hasan (Khwāfì Khān, Muntakhab al-Lubāb, ii, 371 ff.).

\section{DeLHI*}

The city of Delhi, situated on the west bank of the river Yamuna was the capital of the earliest Muslim rulers of India from 608/1211, and remained the capital of the northern dynasties (with occasional exceptions: Daulatabad, Agra, and Lahore were the centres favoured by some rulers) until the deposition of Bahādur Shāh in 1858; from 1911 it became the capital of British India, and after 1947 of Independent India.

* "Dihlī, 1. History; 2. Monuments," EI, II, 255-66. 
The usual Romanized form of the name is Delhi, based on the commonest form in the earlier Muslim usage Dihlī; the common spellings in Urdū, Hindī (certainly from the time of the Prith $\bar{R} \bar{a} j \operatorname{R} \bar{a} s \bar{o}$ of the 13th century), and Panjābī represent Dillī. The etymology is obscure; for some popular etymologies see A. Cunningham, ASI, i, $137 \mathrm{ff}$.

It has become popular to speak of "the seven cities of Delhi"; but the number of centres of government in the Delhi area has in fact been nearer double that number. The earliest settlement was Indrapat, Sanskrit Indraprastha, a tell on which the present Purānā Qil'a stands, supposed to have been built in legendary times by the Pāndavas; the site is certainly old, and potsherds of Painted Grey ware and Northern Black Polished ware, types dating back to the 5th century B.C., as well as Kushāna fragments of the 1st and 2nd centuries A.D., have been discovered there (see $\left.A I, \mathrm{x}^{-} \mathrm{xi}, 1955,140,144\right)$. The region of Delhi seems to have been almost abandoned thereafter, for the next settlement dates from the 9th or 10th century, the Tomār city now known as Sūraj Kund, where a large masonry tank and an earthwork are still in existence. More extensive are the remains of the Chauhān Rājpūt town, dating probably from the 10th century, which existed immediately prior to the Muslim conquest. On a small hill in the south-west of this region a citadel, Lālkōt, was built in c. A.D. 1052 by Ānang Pāl, and around the town an outer wall was thrown, as a defence against the Muslim invaders, by Prithvīrāja in about 576/1180 (Cunningham, (Fig. 1) $A S I$, i, 183). Subsequent to the conquest a mosque, known as Masjid Quwwat al-Islām, was erected in 588/1192 by Quṭb al-Dīn Aybak, who later commenced the building of the adjoining mina $\bar{r}$ not only as a ma'dhana but also as a commemoration of his victory; for these, their extensions by Shams Dīn Iletmish and 'Alā al-Dīn Khaljī, and other buildings in this so-called "Qutb site" see Monuments, below. The systematic refortification and extension of these old Hindu walls was effected by the earliest governors and monarchs to form the first Muslim city of Delhi, known by the name of its former occupant as Qil'a Rāy Pithorā. (For a discussion of the archaeological evidence see J.D. Beglar, ASI, iv, 1874, 6 ff.)

Qil'a Rāy Pithorā remained the only regular residence of the Delhi sultans until Mu izz al-Dīn Kayqubād built his palace at Kilōkhrī, then on the banks of the Yamuna (Briggs, Ferishta, i, 274), in about 688/1289; this was occupied, completed, and its suburbs extended, by Jalāl al-Dīn Fīrūz Khaljī in and after 689/1290. It has now fallen completely into desuetude. Even in Jalāl al-Dīn's case the older city seems to have 
had a higher prestige value, and he moved his court there as soon as it was politically practicable so to do. The sultān 'Alā' al-Dīn Khaljī effected many improvements and repairs, including the west gate (Ranjīt Darwāza) of Lālkōt (Amīr Khusrau, trans. in Elliott and Dowson, iii, 561); he commenced also the extension of the citadel of Lālkōt (see Beglar, op. cit.). As a protection against the invading Mongols he first established a camp on the plain of Sīrī to the north, later encompassed it by entrenchments, and finally walled it, in about 703/1303. The location of Sīrī has been questioned (e.g., by C.J. Campbell, Notes on the history and topography of the ancient cities of Delhi, in FASB, xxxv, 1866, 206-14); but the descriptions of Ibn Bațțāța, iii, 146, 155, and Tīmūr, Malfüzāt-i Timmuri, trans. in Elliott and Dowson, iii, 447, and the ruins and lines of defences on the ground, enabled Campbell's views to be convincingly refuted by Cunningham in $A S I$, i, $207 \mathrm{ff}$. All that now remains within the walls is the comparatively modern village of Shahpur.

Hardly a "city of Delhi", but an important site in its history, is the group of buildings, the earliest of which date from Khalji times, surrounding the (Tughluqāāād) shrine of the Chishtī saint Nizạam al-Dīn Auliyā', which make up the complex now known officially as "Niz̄āmuddīn" (for description of these buildings, see below).

Some of the most ambitious building projects in the time of the Delhi Sultanate were conceived during the rule of the following Tughluq dynasty. Firstly, Ghiyāth al-Dīn Tughluq selected a site some $8 \mathrm{~km}$. to the east of Qil'a Rāy Pithorā, immediately after his defeat of the converted Hindu Nāṣir al-Dīn in 720/1320, for the building of his capital Tughluqābād. The trace of the outer enceinte is approximately a halfhexagon, within which are a more strongly defended palace area, and an even stronger citadel; there are the ruins of a mosque in the city area, and the layout of the streets and houses of the streets and houses of the city, which shows it to have been well populated, can be seen from the aerial photograph in $A I$, i, Pl. IX. On the south of the city was formerly an artificial lake, in which stands the tomb of Ghiyāth al-Dīn, linked to the citadel by a fortified passage supported on arches, itself fortified. Connected with Tughluqābād by a causeway on the south-east, which formed a bund to retain the waters of the lake, is the subsidiary fort of 'Ādilābād built by his son Muhammad b. Tughluq c. 725/1325, but abandoned by him, together with Tughluqābād, in 729/1329 on his transfer of the capital to Daulatabad. (For these sites see the excellent article of H. Waddington, 'Ádilābād: a part of the "fourth" Delhi, in AI, i, 60-76, with photographs and survey plans.) A small fort, known as the 
"Barber's" or "Washerman's" fort (Nāikā/Kōt), to the east possibly a madrasa or a shrine in origin, was fortified and presumably used as a residence for Ghiyāth al-Dīn while Tughluqābād was in building.

About contemporary with the building of 'Ādilābād was Muhammad b. Tughluq's more grandiose project, the walling-in of the suburbs which had grown up between Qil'a Rāy Pithorā and Sīrī to form yet another city, called Jahānpanāh, the walls of which, some $12 \mathrm{~m}$. thick, have almost completely fallen and the exact trace of which cannot easily be located; for the sluice built into this wall near the village of Khirkī, the Sāt Pulāh, see below.

Muhammad's successor Fīrūz Tughluq was responsible for the building of another city, Fīrūzābād, extending from Indrapat to Kushk-i Shikār some $3 \mathrm{~km}$. north-west of the later city of Shāhjahānābād, and now largely covered by that latter city. Its buildings were dilapidated by later builders, especially Shēr Shāh Sūrī and Shāhjahān, and all that remains is the citadel, known as Fìrūz Shāh Kōttā, its walls reduced to below the level of their machicolations, containing a palace complex, the remains of a fine mosque, and an extraordinary pyramidal structure built as a plinth for a column of Ashoka brought from near Ambala; the isolated Qadam Sharîf and the nearby 'ìdgäh show the western extent of the city to have been no further than the later Shāhjahānābād. The extent of Fīrūz Shāh's building activity around Delhi would indicate that the suburbs in his time were still well populated, as evidenced by the two large mosques in Jahānpanāh, another in Nizāamuddīn, and smaller ones in the northern suburbs and in Wazīrābād. A further occupied site was around the old reservoir built by 'Alā' al-Dīn, the Hauz-i 'Alā'î, later known as Hauz-i Khāṣs, where he established a large madrasa and built his own tomb.

The Tīmūrid sack caused the eclipse of Delhi as a capital city for some time, and although the Sayyid governor Khiḍr Khān established his court at Khiḍrābād, and Mubārak Shāh his at Mubārakābād, both on the Yamuna, and the latter sultān built also his own tomb in the fortified village Mubārakpur (also Mubārikpur, Mubārik [sic] Shāh Kōtlā), the Sayyids and their successors the Lōdīs built no further cities at Delhi. The Lōdīs, indeed, moved their seat of government to Agra, and Delhi became little more than a vast necropolis, the plains between Sīrī and Fīrūzābād being covered with tombs and mausolea of this period; especially Khayrpur, $2 \mathrm{~km}$. west of Nizāmuddīn, a region 1 km. west of Mubārikpur ("Tīn Burj", i.e., "three towers"), and a region on the road to Hauz-i Khāṣṣ (Kharērā); there was also some building 
in the region of the reservoir of Iletmish, Hauz-i Shamsī, south of the village of Mehraulī.

After the Mughal invasion in the early 16th century Humāyūn settled at Delhi and started the building of a citadel, Dīnpanāh, on the mound of the old Indrapat in 940/1533, but was dispossessed by the usurper Shēr Shāh Sūrī. Shēr Shāh took over and completed the building of Dīnpanāh, as the citadel of a new city, to which no particular name is given, little of which remains except the northern gate, near Fìrūz Shāh Kōtlā, and the southern gate, opposite the citadel, as most of the stone was removed for the building of Shāhjahānābād. His son and successor Islām Shāh, popularly called Salīm Shāh, built on the Yamuna the fortress Salīmgarh as a bulwark against the return of Humāyūn in about 957/1550. Humāyūn's return five years later added nothing to the Delhi buildings, and the next two Mughal rulers preferred to reside at Agra and Lahore; some buildings at Delhi date, however, from their time, especially the complex of monuments around Humāyun's tomb (see S.A.A. Naqvi, Humāyūn's tomb and adjacent buildings, Delhi 1947). Shāhjahān also reigned at Agra for 11 years, but the inconveniences there caused him to remove to Delhi ('Amal-i Sălih, fols. 575-6; Manucci, Storia do Mogor, i, 183) and found there on 12 Dhu 'l-Hijja 1048/16 April 1639 (so the contemporary historians and inscription in the Khwābgāh; 9 Muharram 1049/12 May 1639 according to the Ma'a-thir al-Umara ${ }^{\prime}$, iii, 464, and Sayyid Aḥmad Khān) a new fort, the citadel of his new city Shāhjahānābād, known as the "Red Fort", Lāl Qil'a, which was completed after nine years. The walling of the city proceeded at the same time, and it was enriched with many more buildings in the reign of Shāhjahān and his successors (notably the Jāmi` Masjid, commenced two years after the completion of the fort), who made no further expansions of any of the successive cities. Shāhjahānābād continued to be the capital of the Mughal rulers - except for Aurangzīb, who spent much time in the Deccan and died at Aurangabad - although other sites around continued to be used; e.g., the Humāyūn's tomb complex, Nizāamuddīn, and the dargāhs of Rōshan Chirāgh-i Dihlī in Jahānpanāh and of Quṭb al-Dīn Kākī at Mehraulī were all used as burial places for the later Mughal rulers, and at Mehrauli is a small summer palace used by the latest Mughals.

With the fall of the Mughal dynasty in 1858, the destruction of many buildings by the British during and after the mutiny, and the transfer of the capital to Calcutta, Delhi became a town of less importance, the head of a local administration and a garrison town. The British expan- 
sion was to the north of Shāhjahānābād, where the Civil Lines were established; here the capital was transferred in 1911, and the building of the new city commenced, originally known as Raisena, later New Delhi, Na乞 Dilli. Later expansion has been westwards of Shāhjahānābād in the Sabzī Mandī, Karōl Bāgh, and Șadr Bāzār quarters; south of Khayrpur and on the road to Mehraulī; around the Cantonment; and north of the Gurgaon road leading to the airport.

Some confusions of nomenclature, omitted in the above description, must be mentioned. Lālkōt and Kil'a Rāy Pithorā were known as "Old Delhi" as early as Tîmūr's time, and this phrase was in regular use in the early British period; since the building of New Delhi the expression "Old Delhi" has often been falsely applied to Shāhjahānābād. After the building of Shāhjahān's new fort, Lāl Qil'a, the older fort of Humāyūn and Shēr Shāh was regularly known as the "Old Fort", Purānā Qil'a or Qil'a-i kuhnā.

\section{Monuments, Sultanate Period}

As the buildings of Delhi present the earliest monuments of a settled Islamic power in the sub-continent, and as it was there that the first characteristic Indian Islamic styles developed, the influence of which was to spread far and wide from Delhi itself, the account of the monuments given here is confined to a simple description of the major works, arranged chronologically, and an account of the architectural features of the monumental complexes of buildings of different periods.

The earliest phase of Muslim building in Delhi is represented, as in the earliest stages in other sites by the re-utilization of pillaged Hindu temple material. This applied to the first mosque constructed in India, Quṭb al-Dīn Aybak's Masjid Quwwat al-Islām, earliest inscription 587/1191-2, in Qil'a Rāy Pithorā: on a temple plinth $37.8 \mathrm{~m}$. by $45.4 \mathrm{~m}$. is constructed the central court, $65.2 \mathrm{~m}$. by $45.4 \mathrm{~m}$., with colonnades of three bays on the east and two on north and south; the western tiw wan is four bays in depth, originally with five domes covering voids in front of the mihrāb recesses, its roof raised at the north end to accomodate a zanāna gallery. The lizwān is separated from the mosque courtyard by a great arched screen, added in 595/1199, whose arches do not conform with the spacing of the columns and mihrābs behind. The columns of the arcades were taken from some 27 Hindu and Jain temples, arranged haphazardly, often set one over another to give the necessary height, ranged to support a roof made from ceiling slabs of 
similar temples, the sculptured figures mutilated and roughly covered with plaster, sometimes turned face inwards. The screen arches are corbelled, ogee at the top, some $2.5 \mathrm{~m}$. thick, the central arch $13.7 \mathrm{~m}$. high with a span of $6.7 \mathrm{~m}$. The whole surface of this maqsüra is covered with carving, Hindu floral motifs and arabesques, and vertical lines of naskh. In the courtyard stands a pillar of rustless malleable iron from a temple of Vishnu of the Gupta period (4th century), doubtless placed there by the builders not only as a curious relic, but also as a symbol of their triumph over the idolaters. At the south-east corner of the mosque Quṭb al-Dīn commenced, after the completion of his mosque, the minaret known as the Quṭb Mīnār, described below.

The reign of Quṭb al-Dīn's successor, Shams Dīn Iletmish, saw an increase in building, not only at Delhi. To the Delhi mosque he attempted to give greater scale and dignity by extensions of the colonnades and the great maqșüra screen - symmetrically disposed as regards the new milhräbs, columnar bays, and the arches of the maqșura, thus indicating a design of homogeneous conception; the new sahn included the mina $r$, to which he added also, and its entrances were arranged coaxially with those of the old mosque. The colonnade is composed of relatively plain columns, and the screen decoration, including Kūfic character and tughra devices, is more obviously the work of a craftsman familiar with his material than is the earlier example. The arches, still corbelled, differ in contour from those of the earlier screen by the absence of the ogee counter-curve at the apex. Immediately west of his northern extension of the mosque is the tomb of Iletmish (c. 632/1235?; no dating inscriptions), a square chamber, originally bearing a circular dome, supported on corbelled squinches, the whole interior surface intricately banded with arabesques, diaperwork, and naskh and Küfic inscriptions (entirely Qur'annic); the exterior is of dressed ashlar, with the arched openings on north, east and south in red sandstone; red sandstone is also used for the interior, with marble on the mihra $\bar{a} b$ wall and the cenotaph; the true grave is in a subterranean tahkhāna.

The Quṭb Mīnār was extended by Iletmish by the addition of three further storeys, to a total height of $69.7 \mathrm{~m}$. (Cunningham, ASI, i, 195), completed c. $626 / 1229$. The angle of slope is about $41^{1} 2^{\circ}$ from the vertical, and the four storeys are separated by balconies supported by stalactite corbelling. Each storey is fluted - developing probably the polygonal outline of the prototype minnar at Ghazni in Afghanistan - the lowest having alternately rounded and angular flutes, the second all rounded, the third all angular; the upper storeys, the work of Fìrūz 
Tughluq (see below), are plain. Each of the three lowest storeys is decorated with wide encircling bands of Arabic inscriptions in naskh (dating inscriptions, panegyrics of Mu izz al-Dīn Muhammad b. Sām and Shams Dīn Iletmish, Qur'ānic verses); features of typically Hindu origin are almost entirely absent.

To the reign of Iletmish belongs the first instance in India of a monumental tomb, the mausoleum of his son Nāṣir al-Dīn Maḥmūd, at Malikpur, of 629/1231. This stands within a plinth some $3 \mathrm{~m}$. high in an octagonal cell, the top of which projects into a courtyard with a plain enclosure wall pierced by corbelled arches, with arcades of Hindu columns on the east and west walls; that on the west forms a small mosque, with central portico and mihrāb. The external gateway bears the dating inscription in Kūfic characters (non-Qur'ānic inscriptions in Kūfic are known only here, at the Masjid Quwwat al-Islām, and at Ajmer); the corner towers appear to be part of Fīrūz Tughluq's restorations (Futūhāt-i Firūz Shāhī, Aligarh ed. 1943, 16). The tomb is locally known as "Sulțān Ghārî", presumably on account of the crypt $(g h \bar{a} r)$ in which Nāṣir al-Dīn is buried, but this name is not known before Sayyid Aḥmad Khān, Āthār al-Sanād̄̄d, lith. Delhi 1848, 206-8. For a detailed study see S.A.A. Naqvi, Sultān Ghārī, Delhi, in AI, iii, 1947, 4-10 and Pls. I-XII.

During the reigns of the suceeding sovereigns no buildings of note were erected until the reign of the Khaljī ruler 'Alā' al-Dīn, except for the tomb of the Sultān Balban, d. 686/1287, in the south-east of Qil'a Rāy Pithorā, larger than the tomb of Iletmish, with side chambers leading off the main hall, in which appears for the first time the use of the true voussoired arch. This marks not only a technical advance in construction but also a strengthening of Islamic building tradition, as opposed to that of the impressed Hindu craftsmen.

'Alā' al-Dīn Khaljī's extensions to the citadel of Lālkōt, and the building of Sīrī, have been mentioned above. He started a grandiose plan of extension to the Quwwat al-Islamm mosque to the north and east; a few columns remain, and the foundations of the north gateway, to show the extent of this, and of the great arched maqșura screen which was intended to be twice as long as the two previous screens combined, and of twice the scale; in the northern courtyard stands the incomplete first storey of a gigantic minār, its diameter at base twice that of the Quṭb Mīnār. The most notable feature of these extensions is the southern gateway, the 'Alā'î Darwāza, of exceptional architectural merit: a square building of $10.5 \mathrm{~m}$. internal dimension, with walls 3.4 
m. thick, is surmounted by a flat dome, with lofty $(10.7 \mathrm{~m}$. from ground level to apex) arches on east, south and west, and a smaller trefoil arch on the north leading to the new eastern extension of the courtyard. The three large arches, and the squinches which support the dome, are of pointed horse-shoe shape, voussoired, with on the intrados a fringe of conventionalized spear-heads. A similar style is seen in the Jamā'at Khāna Dargāh of Niẓām al-Dīn, the first example in India of a mosque built with specially quarried materials, not improvised from Hindu material. (For a discussion of this mosque see M. Zafar Hasan, $A$ guide to Nizämu-d-Din [= MASI, 10], 1922). Apart from the early building (madrasa?) at Hauz 'Alā'̄i (= Hauz-i Khāșș), the only other structure of 'Alā' al-Dīn at Delhi is his tomb and madrasa to the south-west of the Masjid Quwwat al-Islām, now much ruined; the series of small cells on the west wall show for the first time in India domes supported by a corbelled pendentive. For an extensive description of all the monuments and archaeological work see J.A. Page, Historical Memoir on the Qutb, Delhi (= MASI, 22), 1925; idem, Guide to the Qutb, Delhi (abridged from above, with map), Delhi 1938; best illustrations in H.H. Cole, The architecture of ancient Delhi, London 1872.

The achievements of Ghiyāth al-Dīn, the founder of the Tughluq dynasty, are confined to the building of the city of Tughluqābād (see above), and his own two tomb buildings; the first of these is in Multan; the second of these, commenced after leaving the Panjab and coming to Delhi as sovereign, forms an outwork on the south side of Tughluqābād, an irregular pentagon with bastions at each angle, with the tomb-building placed diagonally at the widest part of the enclosed courtyard. This mausoleum is of red sandstone faced with white marble, its walls with a strong batter $\left(25^{\circ}\right.$ the vertical), with a recessed archway in the north, east and south sides (the west side closed for the mihräb) with the "spear-head" fringe introduced under the Khaljīs and a slight ogee curve at the apex. Here the old Hindu trabeate system is joined with the newer arcuate by a lintel being imposed across the base of the arch.

Muhammad b. Tughluq's foundation of 'Ādilābād and Jahānpanāh has been mentioned above; in the walling of the second of these is a sluice or regulator of seven spans, the Sāt Pulāh, with subsidiary arches and end towers, its two storeys of seven arches holding the mechanism for regulating the level of a lake contained within the walls. Another building of his time, near the village of Begampur, is the Bijay Mandal, which has been supposed to be the remains of his Qașr-i Hazār Sitūn, 
with the first example of intersecting vaulting in India; close to this is a superb but nameless tomb, and the Bārah Khambā (see below).

Muhammad b. Tughluq's act in transporting the entire elite population of Delhi to Daulatabad resulted in the dispersal of the northern craftsmen, and the introduction of a rubble-and-plaster phase under the enthusiastic patronage of his successor Fīrūz Shāh (752-90/1351-88). A list of the numerous building projects sponsored by this monarch is given by Shams-i Sirāj 'Afîf, Ta'rīkh-i Fìrūz Shāhì, and by Firishta, and in his own Futūhät-i Fìrūz Shāhi he describes the monuments of his predecessors which he had rebuilt or renovated. These numerous building and restoration projects demanded a strict economy: plans for every undertaking were submitted to the dīwān-i wizāra, and the more expensive building materials, red sandstone and marble, were no longer used. Of Fīnūz Shāh's cities, Fīrūzābād has been mentioned above. The Jāmi 'Masjid within the kōtla stands on a high plinth and the main gate is on the north; the saln was surrounded by deep triple aisles, and around the central octagonal hauz was inscribed the record of the public works of Fìrūz. Only the shell of the building remains, much of the stone having been built into the walls of Shāhjahānābād by British engineers. The other building standing within the kōtla is a three-storeyed pyramidal structure on which is mounted a pillar of Ashoka (3rd century B.C.) brought from Meerut District. For these and other ruins in the citadel see J.A. Page, A memoir on Kotla Firoz Shah, Delhi (= MASI, 52), Delhi 1937. The mosque style of the period is better shown by half a dozen mosques of approximately the decade 766-76/1364-75: all are rubble-and-plaster, presumably originally whitewashed, with pillars and Hindu style brackets and eaves in local grey granite, with prominent gateways, many domed roofs, and tapering ornamental pillars flanking the gateways. The simplest is the mosque in the dargāh of Shāh 'Ālam at Wazīrābād (= Tīmūrpur), a simple west tizeann of five bays, with three domes, within which is the earliest example in Delhi of a zanāna gallery in the rear corner of the tìwan; the large (courtyard $68.0 \mathrm{~m}$. by $75.3 \mathrm{~m}$.) Begampur mosque in the north of Jahānpanāh has the șahn surrounded on all sides by a domed arcade, and the west liwwan has a tall arched pylon in the centre of its façade which completely masks the large central dome; the Sanjar mosque (also called Kālī [black] Masjid) at Nizāmuddīn has the central courtyard divided into four smaller courts each $13.1 \mathrm{~m}$. by $10.1 \mathrm{~m}$. by a cruciform arcade one bay in depth, as well as the domed arcading on all sides (ASI AR, xxvii, Pl. I); the Khirkī mosque, at Khirkī village in 
the south of Jahānpanāh close to the Sāt Pulāh, has a similar arrangement, but the crossing arcades are of three ranks of arches, as are the side liwwāns: hence only the four courts, each $9.8 \mathrm{~m}$. square, are open in the total area of about $52 \mathrm{~m}$. square; the Kalān (this also sometimes miscalled Kālì) Masjid, within the walls of the later Shāhjahānābād, is smaller with a single open court and surrounding domed arcades. This, the Khirkī mosque, and the Jāmi ${ }^{`}$ Masjid in the kōtlāa, are all built on a high plinth over a tahkhāna storey, and the mosques themselves are approached by high flights of steps. The Kalān Masjid was no doubt the main mosque of the new Fìrūzābād suburbs, but the size of the Begampur and Khirkī mosques implies that the older cities still maintained a considerable population. The northern suburbs were further provided for by the Chauburjī mosque on the Ridge, now so altered through various uses that its original plan is hardly discernible; near the mosque is the remains of Fìrūz Shāh's hunting lodge, Kushk-i Shikār or Jahān-numā, to which he repaired for consolation after the death of his son, Fath Khān, in 776/1374. This prince is buried in the Qadam Sharîf, a fortified enclosure (see $A S I A R$, xxii, 4 and Pls. IIIc and d) in which is a domed arcade surrounding the grave, over which is a stone print of the Prophet's foot set in a small tank of water.

Fìrūz's own tomb is coupled with the madrasa he built on the site of 'Alā' al-Dīn's structure at the Hauz-i Khāṣs; the madrasa buildings on the east and south of the hauz, double-storeyed on the lake front and single behind, are colonnades, several bays deep, of arches or linteland-bracket construction, connecting square domed halls at intervals, extending about $76 \mathrm{~m}$. on one shore and $120 \mathrm{~m}$. on the other; at the south-east corner is the $13.7 \mathrm{~m}$. square tomb, with plastered walls slightly battering, the two outer (south and east) walls with a slight projection in which is an arched opening in which the entrance is framed by a lintel-and-bracket; there is a single dome on an octagonal drum, supported by interior squinches, and the west wall, in which is a door to the adjoining hall, has a small mihrāb. The building stands on a short plinth extended southward to form a small terrace, which is surrounded by a stone railing of mortice and tenon construction resembling woodwork. Another tomb, of great architectural significance, is that of Fìrūz's Prime Minister Khān-i Jahān Tilangānī, d. 770/1368-9, within the kōt at Nizāmuddīn; this is the first octagonal tomb at Delhi (although the tomb-chamber at Sulțān Ghārī is octagonal also), and is surrounded by a verandah, each side of which has three arched openings surmounted by a wide chhajj $\bar{a}$ or eaves-stone; there is a central dome, and eight 
smaller dome-like cupolas, one over each face. The prototype of this tomb has been sought in the Dome of the Rock in Jerusalem; it formed the model for many royal tombs of the subsequent "Sayyid", Lōdī and Sūrī dynasties. One of the latest buildings of the Tughluqs is the tomb of the shaykh Kabīr al-Dīn Auliyāà (probably of the time of Nāșir al-Dīn Mạmūē, after 796/1394); although an indifferent (Nizāmuddīn) and half-scale copy of the tomb of Ghiyāth Dīn Tughluq, it is of interest in indicating a revival of sympathy for the earlier polychromatic style, a reaction against the Fīrūzian austerity. On Fìrūz Shāh's tunnels at Delhi, see H. Hosten, in $\mathcal{J A S B}$, n.s. vii (1911), 99-108; viii (1912), 279-81; ix (1913), lxxxiii-xci.

Since the major structures at the shrine of Nizām al-Dīn are of this time the complex is described here. The entrance gate bears the date $780 / 1378-9$, within which is a large $b \bar{a} o l \bar{t}$ flanked by two tombs and a two-storeyed mosque, all of Fìrūzian appearance; the $b \bar{a}$ olt is named Chashma-i dil kushā $(=703 / 1303-4$ by abjad $)$. A further gate leads to the shrine enclosure; the shaykh's tomb dates from the time of Akbar, replacing an earlier one built by Fīrūz Tughluq, but has been much restored since, the dome being an addition of Akbar Shāh II in 1823; the Jamā'a Khāna mosque, to the west of the tomb, has already been referred to. To the south of the enclosure are numerous graves (Jahānārā, daughter of Shāhjahān; Muhammad Shāh, d. 1161/1748; Jahāngīr, son of Akbar II; Amīr Khusrau, a contemporary of the shaykh, although the tomb is early 17th century; and others); outside the east wall of the court is the square polychromatic tomb of Atga Khān, foster-father of Akbar, d. 969/1562, of a style similar to that of Humāyūn (see below). Some $60 \mathrm{~m}$. south-east of this tomb is the Chausath Khambe, a grey marble pavilion of excellent proportions forming the family burial place of Atga Khān's son, Mīrzā 'Azīz Kōkaltash, d. 1033/1624. The adjoining kōt and Tilangānī tomb have already been noticed. For a full account of all these buildings see M. Zafar Hasan, A guide to Nizāmu-d-Din (= MASI, 10), Calcutta 1922.

Another dargāh largely dating from Fūrūz's times is that of Nașir alDīn Chirāgh-i Dihlī, d. 757/1356; the east gate is of 775/1373, but the tomb has been much modernized; the walls enclosing the shrine and village were built by Mụ̣ammad Shāh in 1142/1729; beside stands one of the alleged tombs of Bahlōl Lōdī.

The "Sayyid" and Lōdī dynasties produced no great building projects; their monuments consist entirely of tombs, except for one significant mosque, and the principal ones are concentrated in three sites: 
Khayrpur, Mubārakpur, and south of Mujāhidpur on the road to Hauz-i Khāș. The tombs are of two distinct types, square and octagonal, in both cases with a large central dome, frequently also with open chhatris above the parapets. The earliest octagonal example is that of Mubārak Shāh, d. 838/1434, in Kōtlā Mubārakpur, an improvement on the style of the Tilangāni tomb, although the dome is not high enough and the octagonal chhatris over each face are too crowded. The tomb of Muhammad Shāh, ten years later, removes these defects by raising the drum of the dome and the chhatris, andadding a guldasta at each angle of the verandah parapet. The tomb of Sikandar Lōdī, c. 924/1518, at the north end of Khayrpur, is of similar proportions but without the chhatris, and the dome has an inner and outer shell; the mausoleum stands in a fortified enclosure, on the west wall of which is an arrangement of arches resembling an $\bar{\imath} d g \bar{a} h$, presumably an outdoor mihra $\bar{a} b$. The tomb of Mubārak has a detached mosque, but that of Muhammad has none. All tombs have sloping buttresses at the angles.

The square tombs probably all date from the last quarter of the 15th century, but they lack inscriptions and are known only by very uninformative local names. The finest is the Barē Khān kā Gunbad, "Big Khān's dome", the largest (height $25 \mathrm{~m}$.) of the three known as Tīn Burj, west of Mubārakpur, apparently of three storeys from the exterior, but actually a single hall; this and the adjoining "Little Khān's dome" have octagonal chhatris in the angles of the square below the drum, as had the Dādī kā ("Grandmother's") and Potī kā ("Granddaughter's") Gunbad of the Mujāhidpur group. At Khayrpur are the best preserved, the Barā Gunbad ("Big dome"), date 899/1494, which has no graves within and is locally said to be a gateway to the attached mosque, court-yard and majlis-khana (?). The mosque has massive tapering and sloping pillars at each rear angle, each with a band of fluting, alternately rounded and angled, reminiscent of the lowest storey of the Quṭb Mīnār; the east façade has wide central arches whose spandrels are filled with the best cut-plaster decoration in Delhi. Near is the Shīsh Gunbad, very similar to the Barā Gunbad, but with courses of dark blue encaustic tile work.

Apart from the mosque mentioned above, the Lōdīs produced one major example of this class, the isolated Moth ki Masjid south of Mubārakpur, built by the wazìr of Sikandar Lōdī c. 911/1505; the west wall shows similar tapering pillar-turrets, but at the angles of the projecting mihrāb, and the external angles are provided with two-storeyed 
open towers; the side walls have trabeate balconies; the façade of the west liwe $\bar{a}$ has the contours of the arches emphasized by the recession of planes of the intrados, and the central arch is emphasized further by a pylon-like structure of the same height as the remainder; the liwan side domes are supported on stalactite pendentives; white marble, red sandstone, and coloured encaustic tiles are used in the decorative scheme, as well as fine cut-plaster; it is aesthetically one of the liveliest buildings in the whole of Islamic art in India. Other buildings of the Lōdīs are few: a structure (madrasa?), incorporating a small mosque, known as the Jahāz Mahall, on the east side of the Hauz-i 'Alā'ì at Mehraulī, a few small bāradarìs and mahalls near Niz̄āmuddīn, and the residence (Bārah Khambā), with enclosed courtyard and three-storeyed tower, at Begampur.

In the unsettled days of the early Mughal conquest the Lōdi mode seems to have continued: the Jamāli mosque of 943/1536, in the south of Qil'a Rāy Pithōrā, has fine ashlar masonry, five tìwān arches with recession of planes in the intrados, and the central archway sunk in a larger arch, with a spearhead fringe, in a central propylon rising above the general level of the façade, with a single central dome. Immediately to the north is the insignificant-looking oblong building over the tomb of Fazl Allāh, takhallus Jamālī, with the best colour decoration in Delhi on its ceiling. A continuation of the octagonal tomb style is in that of 'İsā Khān Niyāzī, of 954/1547-8, and hence in the reign of Islām Shāh Sūrī; the construction is similar to the preceding examples, including the closed west wall and mihrāb, but more encaustic tile remains; a separate mosque stands on the west of the octagonal courtyard, of grey quartzite and red sandstone, the central bay of the three set in a projecting portico, with a central dome and chhatris over the side bays. The tomb-building has sloping buttresses at each angle, and is the last building in Delhi so treated. (For these monuments see Naqvi, Humāyunn's tomb...op. cit., 21-4). The last octagonal tomb in Delhi was built some fourteen years later, in the reign of Akbar, the tomb of Adham Khān in the extreme south-west of Qil'a Rāy Pithōrā; this seeks to obtain additional elevation by converting the drum of the dome into an intermediate storey, arcaded externally, and without chhatris; the thick walls of the drum contain a labyrinth of stairways. Its general effect, though, is rather spiritless (photograph and brief description in Cole, op. cit.). 


\section{Monuments, Mughal period}

The first two Mughal emperors, Bābur and Humāyūn in his first period, added nothing to Delhi's monuments, except perhaps the commencement of the Purānā Qil'a; this, however, was mostly the work of the usurper Shēr Shāh Sūrī, as a citadel for his new city. Of the city only two gateways remain, the northern (Lāl, Kābulī or Khūnī Darwāza), opposite Fīrūz Shāh Kōtlā, and the southern, with a short stretch of walling, near Purānā Qil'a (see $A S I A R$, xxii, 6 and Pl. II). Of the citadel the walls remain, and two major structures within, the Shēr Mandal, a two-storeyed octagon of red sandstone of unknown original purpose, but used by Humāyūn as a library and from which he fell to his death; and the mosque, with no distinctive name, which has the Jamāli mosque as its immediate prototype: but each of the five façade bays has a smaller recessed archway, and every other feature of the earlier mosque is improved and refined in this later example. The external construction is in coursed ashlar, and the liw $w \bar{a}$ façade in red sandstone, some of it finely carved, embellished with white marble and polychromatic encaustic tile work; inside the central dome is supported by two ranks of squinches, and in the side bays stalactite pendentives support the roof; the rear wall has tapering turrets on each side of the milhräb projection, and an open octagonal turret at each angle.

The first major building of the Mughals in Delhi is the tomb of the emperor Humāyūn, of a style already prefigured in the small tomb of Atga Khān at Nizāmuddīn; the foundations of it were laid in 976/1568-9 (so Sangīn Beg, Siyar al-Manāzil, MS in Delhi Fort Museum; 973/1565 according to Sayyid Aḥmad Khān, followed by most later writers) by his widow, employing the Persian architect Mirzā Ghiyāth, although the enclosure wall had been started some five years before. In a large square garden enclosure ( $340 \mathrm{~m}$. side; this is the first chār-bāgh garden in India still preserving its original plan) stands the mausoleum building, $47.5 \mathrm{~m}$. square on a plinth $95 \mathrm{~m}$. square, $6.7 \mathrm{~m}$. high; each face is alike, having a central rectangular fronton containing an immense arch, flanked by smaller wings each containing a smaller arch; these wings are octagonal in plan and project in front of the main arches. The central chamber is surmounted by a bulbous double dome on a high collar, around which are chhatrīs over the corner wings and portals. The entire building is in red sandstone, with a liberal use of white and coloured marble. Neighbouring structures are the small $\mathrm{Na}_{\bar{a}} \overline{\mathbf{1}}$ kā Gunbad, "Barber's dome"; the Nīlā Gunbad, "Blue dome", earlier 
than Humāyūn's tomb and therefore not the tomb of Fahīm Khān, d. 1035/1626, as often stated; the "Afsarwālā" tomb and mosque; the 'Arab Sarā'ī; and the tomb of 'Īsā Khān already described (full description of these buildings in Naqvi, Humāyunn's tomb...op. cit.). Not far to the south is the tomb of 'Abd al-Rahīm, Khān-i Khānān, d. 1036/ 1626-7, a similar structure but smaller and without the octagonal corner compartments - hence a more obvious forerunner of the Tāj Mahall than Humāyūn's tomb; the white marble of this building was later stripped off by Āsaf ad-Daula, wazīr of Awadh. Other early Mughal buildings are the Lāl Chauk or Khayr al-Manāzil (the latter name a chronogram, $969=1561-2$ ), a mosque built by Māham Anaga, foster-mother of Akbar, with double-storeyed chambers on east, south and north forming a madrasa (ASI AR, xxii, 6 and Pls. Ia and b; inscriptions, MASI, 47, 10); and the mosque of Shaykh 'Abd al-Nabī, șadr al-ṣudūr of Akbar, between Fīrūz Shāh Kōtlā and the Purānā Qil'a, built 983/1575-6 (see M. Zafar Hasan, Mosque of Shaikh 'Abdu-n Nabi (= MASI, 9), Calcutta 1921).

The main phase of Mughal building in Delhi was the construction of Shāhjahānābād and the Red Fort, Lāl Qil'a, founded 1048/1638. Within the palace enclosure, about 950 by $505 \mathrm{~m}$., are a central court containing the Dīwān-i 'Āmm; flanking this, two open spaces containing gardens; and, on the eastern wall, the range of palaces facing inwards to the gardens and outwards to the river. The Dīwān-i 'Āmm is of red sandstone, with slender double columns on the open sides; this and the palace buildings on the east have engrailed arches, stand on low plinths, and most have open chhatris at each corner of the roof. Through the palaces runs an ornamental canal, the Nahr-i Bihisht, which flows south from the Shāh Burj, water being brought from a point 30 kōs up the Yamuna (through the Western Yamuna canal; for the history of this, which dates from the time of Fīrūz Shāh Tughluq, see J.J. Hatten, History and description of government canals in the Punjab, Lahore n.d., 1-3); this has a plain marble channel, which in the Rang Mahall flows into a large tank in which is set a marble lotus, having previously passed, in the royal private apartments, under a screen bearing a representation of the "Scales of Justice" (mizzann-i 'adl). Off these apartments is the external octagonal balcony, the Muthamman Burj, from which the emperor gave the darshan. The Rang Mahall and the Dīwān-i Khāṣṣ are the most lavishly ornate of these palaces, built and paved in white marble, the piers of the arches inlaid with floral designs in pietra dura; the latter building contained the fabulous Peacock Throne (takht-i țâuss), taken to 
Persia by Nādir Shāh in 1152/1739 and there broken up (G.N. Gurzon, Persia and the Persian question, i, 321-2). The fort originally contained no mosque; the Mōtī Masjid was added by Aurangzīb in 1073/1662-3, entirely of white marble, with a curved "Bengali" cornice over the central bay. For the fort and its buildings, see G. Sanderson, $A$ guide to the buildings and gardens, Delhi Fort, Delhi 1937.

The Jāmi` Masjid of Shāhjahānābād (named Masjid-i Jahān-numāa), built 1057-9/1648-50, stands on an open plain to the west of the Lāl Qil'a, its high basement storey, with blind arches on all sides, built on an outcrop of the local Aravalli ridge. The gates on north, east and south have an external opening in the form of a half-dome with a smaller door in the base of each. The east gate, used as the royal entrance, is the largest. The tiwan surrounding the court is open to the outside, and has a square burj, surmounted by an open chhatri, at each angle. The western sanctuary is a detached compartment $79 \mathrm{~m}$. by $27.5 \mathrm{~m}$. with the (Lāl Qil'a) courtyard (99 m. square), with a wide central arch flanked by five smaller bays of engrailed arches on each side, and a three-storeyed minaret at each front angle; above are three bulbous domes of white marble with slender vertical stripes of black marble. The mosque as a whole is in red sandstone, with white marble facings on the sanctuary, and white marble vertical stripes on the minarets. Nearly contemporary is the Fathpurī Masjid at the west end of Chandnī Chauk, the main street of Shāhjahānābād, of similar style but less refinement, with a single dome; there is a mosque school within the enclosure. A smaller mosque of similar style, but with the three domes more bulbous and with equal black and white marble stripes, is the Zinnat al-Masājid, c. 1112/1700, in the east (river) quarter of Shāhjahānābād.

Of the latest Mughal phase must be mentioned the Mōtī Masjid in the dargāh of Quṭb al-Dīn Auliyā' at Mehraulī (early 18th century); the tomb, madrasa and mosque of Ghāzī al-Dīn Khān, father of Āṣaf Jāh, in a hornwork outside the Ajmer gate of Shāhjahānābād (1122/1710), and where the Arabic school is still maintained; the gateway of the Qudsiya Bāgh, north of the Kashmir gate, c. 1163/1750, and the elegant diminutive mosque (Sonahrī Masjid ) of Jāwid Khān, of fawncoloured sandstone, of the same time; and the finely-proportioned fawn sandstone tomb of Safdar Jang, d. 1166/1753, standing in the last great Mughal garden.

The vast building projects of New Delhi ( $\mathrm{Na} \imath \mathrm{Dill} \bar{\imath})$ show occasional reminiscences of the glory of Mughal building, but have no further Islamic significance. 
DHAR*

From the architectural point of view the monuments of Dhar are important only as illustration of the earliest phase of the Malwa style, one of the characteristic provincial styles of Indian Islamic architecture. The earliest mosque building is that in the tomb enclosure of Kamāl Dīn Mālawī (locally called Kamāl Maula), a disciple of Nizāām al-Dīn Auliyā of Delhi; the oldest grave inscription in this enclosure is of 795/1392-3, which records that the ruling sovereign was Mahmūd Tughluq, whose local representative was Dilāwar Khān. This, and the slightly later Jāmi` Masjid, are both adaptations from pillaged Hindu temple material, of trabeate construction; the outer portico of the Jāmi ' Masjid shows an attempt to integrate the trabeate façade by the interposing of pointed arches, of no structural significance, between the columns, the forerunner of the arrangement in the mosque of Malik Mughith at Mandu. The Jāmi Masjid bears inscriptions of $807 / 1404-5$ on the east entrance, and of 15 Rajab 807/17 January 1405 on the north entrance (presumably misread by Jahāngīr, Tūzuk-i Jahāngīñ, Persian text 201-2); for these see EIM, 1909-10, 11-2 and Pls. III and IV. A third mosque of similar style and date is the so-called School of Rājā Bhoj, which owes its misnomer to numerous paving slabs and pillar stones carved with mnemonic rules of Sanskrit grammar.

Later buildings almost all owe their origin to the first Khaljī ruler of Malwa, Mahmūd Shāh (839-873/1436-69), including the restoration of perhaps the oldest Muslim tomb in Dhar, that of 'Abd Allāh Shāh Changāl, who is said to have converted "Rājā Bhōj" to Islam; it has been disputed whether this refers to Bhōja I (r. 1010-1053), a broadminded and tolerant but nevertheless strict Shaiva Hindu - in which case this pir could perhaps have come to Malwa with the army of Mahmund of Ghazni - or to Bhōja II (r. 1280-1310), at a time when conversion to Islam might have been politically expedient for the ruler of a small state; nothing is known of this pirr, and the story of Bhōja's conversion is now regarded as most doubtful, but the inscription erected by Maḥmūd Shāh in 859/1455 (EIM, 1909-10, 1-5 and Pl. I; 42 couplets of Persian verse, one of the longest Persian inscriptions in India) shows the then implicit belief in this tradition. To Mahmūd Shāh is due also the restoration of the tomb of Kamāl Dīn (inscription over doorway of

\footnotetext{
* “Dhār, 2. Monuments," EI, II, 219.
} 
861/1456-7); a tomb opposite that of the pir is said by local tradition to be Mahmūd's own.

The Jāmi Masjid is known in later times as the Lāt Masjid, from the iron pillar $(l \bar{a} t)$ - probably a victory pillar of a local Paramāra king in the early 13th century, cf. ASI AR, 1902-3, 203- lying outside; this pillar bears an inscription recording Akbar's brief stay in Dhar in 1008/1599, its position showing that the pillar had already fallen.

The fort, now empty of internal buildings, is said to have been built by Muhammad b. Tughluq on his way to the conquest of the Deccan; no adequate description of it exists.

\section{ETAWA*}

A district in the south-west of Uttar Pradesh, and also the principal town of that district on the river Yamuna. Other forms of spelling of the name of Etawa are Etaya (Elphinstone), Itay (de Laet), and sometimes Intawa in the Muslim chronicles. Popular etymology connects the name with int a a wāa, "brick kiln".

The region of Etawa was probably within the kingdom of Kanauj at the time of the raid on that kingdom by Mahmūd of Ghazni in 409/1018, and again at the capture of Kanauj by Quṭ al-Dīn Aybak for Muhammad b. Sām in 589/1193. Many Rājpūt chieftains seem to have brought their clans to settle in this region in the early 13 th century, and gathered round them the more turbulent of the disaffected Hindu population. Their intransigence persisted, and many expeditions to enforce the payment of revenues were launched by successive Delhi sultāns; thus Fīrūz Shāh Tughluq was compelled to put down a rebellion of zamīndārs there in 779/1377 (Yahyā b. Ahmad, Tảrīkh-i Mubārak Shāhī, ed. Bibl. Ind., Calcutta 1931, 133-4; tr. K.K. Basu, Baroda 1932, 141; Firishta, Lucknow lith., i, 148); the refractory chieftains Sumer Sāh, Bīr Singh and Rāwat Uddharan - these names are much distorted in the Muslim chronicles and their translations - were in 794/1391-2 defeated by the sulțān Nāṣir al-Dīn Muhammad Tughluq in person, who is said (Yahyā b. Ahmad, op. cit., 152, tr. 161) to have destroyed the fort, although references to a fort abound in later years. Mahmūd Tughluq's governor, the Khwāja-i Jahān Malik Sarwar, began his gov-

\footnotetext{
* "Itāwa," EI, IV, 276-7.
} 
ernorship by leading a force against the rebels of Etawa and Kanauj in Rajab 796/May 1394 (Yahyā b. Aḥmad, op. cit., 156, tr. 164). After this time the Etawa region, lying between the spheres of influence of the Jaunpur sultāns and the factions contending for power at Delhi, was frequently invaded from both sides; thus by Mallū Khān Lōdī in 803/1400-1 (Yahyā b. Aḥmad, op. cit., 169 ff., tr. 175 ff.) and again in 807/1404-5, when after a four months' siege the rebels offered tribute and a gift of elephants. In 817/1414, shortly after his accession, the Delhi sulțān Khiḍr Khān the Sayyid sent out a large force under Tāj al-Mulk who, having received homage from Sumer and others, punished the infidels of Etawa (kuffär-i itāwa rā gūshmāl dāada; ibid., 185); he led further expeditions there in 821/1418 and 823/1420 when the village of Dihuli (Deoli, Duhli, even Delhi in translations!) was destroyed and Sumer besieged in Etawa. It would thus appear that the annual revenues of the district could be collected only by armed force, and only in 825/1422, when the son of Sumer had temporarily joined the forces of Mubārak Shāh, was no foray made against this region.

After the conclusion of a further expedition in 831/1427 the region was invaded by the army of the Jaunpur sultān Ibrāhīm under his brother Mukhtaș Khān, and the Delhi army had to return to meet the danger; not for two years, however, could an army be spared to bring Etawa again under subjection, but Sayyid power was declining and the fragmentation of the old Delhi Sultanate left the district little disturbed thereafter. In the division of the lower $D \bar{o}^{-} \bar{a} b$ territories between the first Lōdī sulțān, Bahlūl, and Maḥmūd Shāh Sharqī in 855/1451, Etawa passed to Jaunpur. A series of inconclusive disputes followed between Bahlūl and the three successive Jaunpur sulțans Mahmūd, Muhammad and Husayn, the last of whom seems to have made Etawa his temporary headquarters ("Bībī Rājì̄" the queen mother died here in 891/1486), and in 892/1487 Husayn's attack on Bahlūl was repulsed and Etawa taken for the Lōdī kingdom. It remained in Lōdī hands until 934/1528 when, on Bābur's invasion of the district, it was surrendered to him.

After the defeat of Humāyūn in 952/1545 the region passed to Shēr Shāh, who effected the partial pacification of the district by bringing in a force of 12,000 horsemen and by his efforts in opening up the country through a road building programme. Neither he nor Akbar seems to have found its absorption into the state administration easy, although it retained some prestige when Akbar made the town of Etawa the chief headquarters of a pargana; the town is mentioned in the $\bar{A} i \bar{\imath}-i$ Akbari as possessing a brick fort, and some reference is occasionally made to Etawa 
as a banking centre. It seems never to have been settled by Muslims to the same extent as other towns of the $D \bar{o}$ a $b$, and after the decline of the Mughal power fell into Marāthā or Jāt hands, with Awadh sometimes powerful enough to gain control over it. Even after the district became part of the lands ceded by Awadh to the East India Company in 1801, many local chiefs retained a considerable measure of independence; the town had some prominence in the struggles of 1857.

\section{Monuments}

Etawa town has an interesting Jami' Masjid, built out of Hindu temple spoli, the western tiwe an of which has a massive central propylon-type arch similar to those of the Jaunpur mosques; it has not been adequately studied, the only account being C. Horne, Notes on the Jumma Masjid of Etawah, in $\mathcal{F A S B}$, xxxvi/1 (1867), 74-5. The central square of Etawa is called "Humeganj", the name commemorating A.O. Hume, the Scots Collector of the district who played a prominent part in the foundation of the Indian Congress Party.

\section{GAWILGARH*}

Gawilgarh, or merely Gawil, a fortress "of almost matchless strength" (Abu 'l-Fazl, A' '̀n-i Akbarī, Eng. tr. Jarrett, ii, 237) is situated in Berar, Central India, $7 k \bar{s}$ (about $25 \mathrm{~km}$.) north-west of Elichpur. According to Firishta the fortress was built by Aḥmad Shāh Walī Bahman̄̄ in 829/1425-6; but from its name it appears to have been a former stronghold of the Gāwalī chiefs, and it is more likely that Ahmad Shāh merely strengthened the fortifications during the year he spent at Elichpur in the consolidation of his northern frontiers before proceeding to his attacks on the Vijayanagara kingdom on his south. A Brāhman captured in an earlier Vijayanagara campaign who was received into Islam under the name Fath Allāh was sent for service under the governor of Berar; later, under the Bahmanī minister Maḥmūd Gāwān, this Fath Allāh, with the title Imād al-Mulk, was himself made governor in 876/1471. The increasing loss of power by the Bahmani sultāns to their Barīdī ministers in the capital, Bidar, had led Fatḥ Allāh to

\footnotetext{
* “Gāwilgaŕh,” EI, II, 981.
} 
prepare against possible opposition by strengthening the defences of Gawilgarh in 893/1488 (inscription on Fath Darwāza), from which time also dates the rebuilding of the Jāmi' Masjid "with the old stones" and Fath Allah's use of the Vijayanagara emblems on the gates (see below). Two years later Fath Allāh assumed independence with headquarters at Elichpur and the fortresses of Gawilgarh and Narnala as his strongholds, and these remained 'Imād Shāhī possessions until the extinction of the dynasty in 982/1574 when Berar became a province of the Niz̄ām Shāhī dynasty of Ahmadnagar. After the cession of Berar to the Mughals in 1004/1596 Gawilgarh was still held by amirs of Ahmadnagar, and Akbar's son Prince Murād, reluctant to besiege it, made Balapur his principal stronghold; two years later, however, it fell to Abu'l-Fazl. The description of the süba of Berar was added to the $\bar{A}^{\prime} \bar{\imath} n-i$ Akbari immediately after the cession of Berar, obviously before the Mughals had had time to reorganize the province, and thus the place given to Gawilgarh as the largest and richest of the thirteen sarkārs must reflect the pre-Mughal administrative division. This division was substantially unchanged in the great scheme of reorganization of the Deccan provinces under Aurangzīb as viceroy in 1046/1636. In the Marāthà troubles in the Deccan in the early 18th century the province was held together by Āṣaf Jāh Niẓām al-Mulk, but on his absence in Dehli in 1151/1738 Berar with its great fortresses of Gawilgarh and Narnala was taken by the Bhōnslē Marāthās. In 1803 Gawilgarh fell to Wellesley, but was retained by the Bhōnslē in the treaty which followed; in 1822, however, it was restored to the Nizām. In 1853 it was assigned to the East India Company, and the fortifications were dismantled five years later.

\section{Monuments}

Much of the walling of the fort still remains, with gates and bastions. One fine tall bastion on the west wall, the Burj-i Bahrām, gives its date of repair (985/1577 by chronogram) by Bahrām Khān, governor of Gawilgarh under the Nizāam Shāhīs at a time when it was expected that Akbar's forces would advance. The Delhi Darwāza is most interesting for its sculptured symbols: the lions with elephants beneath their paws, level with the top of the arch, are devices of the Gond kings, but the two-headed eagles holding elephants in each beak, which lie over the lions, are the gandabherunda symbols of the Vijayanagara empire; this is the northern gate, which leads to the outer fort built in the 18th 
century by the Marāthā Bhōnslēs of Nagpur. The Jāmi' Masjid stands on the highest point within the fort, and in its present form doubtless represents the rebuilding by Fath Allāh recorded in the inscription on the Fath (south-west) Darwāza; the western lìwān was three bays deep behind the seven-arched façade, on which was some blue tile decoration in addition to fine stonework, and bore a rich chhajja on carved brackets; the mihräb wall has fallen. The most interesting feature, characteristic of the local style, is the pylon standing at each end of the lìwān façade, which bears not a minnār as in the other Deccan styles but a square chhatr $\bar{\imath}$ with projecting eaves, rich brackets, and $j \bar{a} t \bar{\imath}$ screens in each side. A large walled șahn stands in front of the tīwann, with a great eastern gateway. To the north-east of the great mosque stands a smaller unnamed mosque, similar but supported on octagonal columns. Few other buildings remain.

\section{GULBARGA*}

This city in northern Karnataka formed part of the domains of the Kākatîyas of Warangal before the Islamic conquest. It was annexed for the Delhi Sultanate by Ulugh Khān, the future Muhammad b. Tughluq, early in the 14th century, to pass first to the Bahmanī dynasty on its establishment in 848/1347, whose first capital it became under the name Ahsanabad. It fell to the 'Ādil Shāhīs of Bijapur in 909/1504, and although it was recovered by Amīr Barīd ten years later it was soon retaken by the 'Ādil Shāhīs; they held it until 1067/1657, when Mīr Jumla besieged it and captured it for the Mughals.

\section{Monuments}

The fortifications of Gulbarga are well preserved, with double walls $16 \mathrm{~m}$. thick, surrounded by a moat often $30 \mathrm{~m}$. wide, well provided with bastions - many with barbettes added later for the use of artillery - and hornworks, large and compound crenellations, machicolations and bartizans. The one major structure standing intact within the walls is the Jāmi` Masjid, built in 769/1367 by a hereditary Persian architect, Rafî̀

\footnotetext{
* "Bahmanīs," EI, I, 925; “Gulbargā,” EI, II, 1135.
} 
b. Shams b. Manșūr Pazvīnī (inscr., Haig, EIM 1907-8, 2), of a type unknown elsewhere in India, without open șahn but completely roofed over forming a pillared hall whose only illumination comes from the open side aisles and the clerestory of the central dome. The side aisles are characterised by their very wide span with unusually low imposts, an arch pattern used elsewhere in Gulbarga. Two mosques of nearly the same period at Delhi are partially covered; but this type was not imitated, presumably since the liwan and minbar were obstructed from the view of most of the congregation.

The other Bahmanī monuments at Gulbarga are the two groups of tombs. The first, near the north-west gate of the fort, includes those of 'Alā' al-Dīn (759/1358), Muhammad I, to whom the Shāh Bāzār Masjid, an unpretentious building in the contemporary Tughluq style of Delhi, is attributed (776/1375), and Muhammad II (799/1397); the first two of these show the battering walls and weak semicircular dome of the Delhi Tughluq style; that of Muhammad II shows a similar dome, stilted below the haunch, to that of the Jāmi 'Masjid. To the east of the city is the Haft Gunbad, including the tombs of Mujāhid and Dā'ūd c. 781/1380, Ghiyāth al-Dīn (c. 799/1397) and Fīrūz (c. 823/1420); some of these are two adjacent domed chambers on a single plinth. That of Ghiyāth al-Dīn shows some Hindu influence in the mihra $r \bar{b}$, and that of Fìrūz in the carved polished black stone exterior pilasters, the dripstones and brackets; the interior of the latter is quasiPersian in its paint and plaster decoration similar to the contemporary Sayyid and Lōdī tombs at Delhi. Of other buildings, the dargāh of Banda Nawāz (Rauza-i Buzurg), c. 816/1413, shows the characteristic wide arch with low imposts.

Additional monuments of Gulbarga include: Qalandhar Khān's mosque (ARADHS, 1925-6, 7 ff., Pls. IIa, Xb), built by a Bahman̄ governor after the transfer of the capital to Bidar; the mosque of Afzal Khān, an 'Ādil Shāhī general of the late 16th century (Mīrzā Ibrāhīm, Basātīn-i Salātīn, 130 ff), which stands in the court of the dargāh of Gēsū Darāz, in the later stone Bijapur style, similar to the mosque of Malika Jahān at Bijapur, with hanging stone chains below the cornice (ARADHS, 1925-6, 8, Pls. IIb, XIa); the Langar mosque, early Bahmanī or possibly pre-Bahmanī, with a vaulted arch-shaped ceiling with wooden ribs recalling the style of the Buddhist cave-temples (ARADHS, 1936-7, 7 ff., Pl. VIa); a group of five mausolea at Holkonda, once a suburb of Gulbarga on the Homnabad road, similar to those of the Haft Gunbad (ARADHS, 1934-5, 1); the mosque and dargāh of Hazrat 
Kamāl Mujarrad (ibid., 5-6 and Pls. IIIa and b); the tomb of Chānd Bībī, of Nizāām Shāhī style (ibid., 6, Pls. IVa and b).

\section{HАMPI*}

Hampi is the name now commonly given to the ruins of the capital city of the Vijayanagara, empire, on the right bank of the Tungabhadra river, $60 \mathrm{~km}$. north-west of Bellary. The name seems to be derived from the prominent temple to Pampāpati (Kannada $h<$ Old Kann. $p$ ) in the $b \bar{a} z \bar{a} r$ area.

The Vijayanagara empire is of importance for the Muslim world not only as an active Hindu power which defied its Muslim neighbours for over two centuries, but also for the evidence it offers of the progressive synthesis of certain aspects of Hindu and Muslim cultures from the 14 th to the 16th centuries; this article is concerned with that synthesis as expressed in its buildings.

Most of the buildings of Vijayanagara are characteristically Hindu works in the late Hoysala style; but in some the Muslim influence is apparent, especially where the building concerned is (presumably) one built for the Muslim community or by a section of it. It is known that the ruler Devarāya I (A.D. 1406-22) had many Muslim mercenaries in his service: the first of his line to appreciate the advantages of cavalry, he had imported many horses from Arabia and Persia and enlisted trained troopers to ride them; and reference is made also to the 'Turkish' bowmen he attracted by liberal grants of cash and land (the adjective is perhaps not to be taken literally, as turaka, turashka in nonMuslim Indian texts frequently means no more than 'Muslim'). They are no doubt responsible for reconstructions in the walls and gates of the citadel of Hampi: thus, the northern gate is of the typical Hindu beam-and-bracket construction, but the remains of the turret above it show arches and parapets of the same general shape as exhibited in the Bahmanī buildings at Gulbarga; the southern gateway, one of the main entrances to the city, shows a tall domed structure supported on four open arched sides, similar to the late Bahmanī and Barīd Shāhī tombs at Bidar. Within the citadel is a large high-walled enclosure generally referred to as the zanana; the accounts of travellers to the

\footnotetext{
* "Hampi," EI, III, 147-8.
} 
Vijayanagara court suggest that the kings did indeed keep their women in seclusion - a practice which was known in early Hinduism but seems to have been most freely adopted by Hindus as a direct imitation of Muslim practice - but that they were allowed to watch spectacles taking place in the city. The so-called "watch towers" on the walls of the enclosure appear to have been built for the pleasure of the ladies of the zanāna, a purpose similar to that seen in the Mughal palaces; these towers, one square and one octagonal, have arched openings on all their faces and are thus strikingly unlike any other Hindu work in the sub-continent, although the synthesis of the Hindu and Muslim styles appears here in that the roofs are of the stepped pattern which characterizes the temple roof (sikhara). Within the enclosure stands the finest and most complete of the mixed-style buildings, known as the Lotus Mahall; this is an open pavilion on the ground floor, with massive piers and foliated arches showing a triple recession of planes of the intrados which recalls the style of the Lōdī mosques of Delhi. The upper storey is provided with numerous small arched windows in each face, originally equipped with wooden shutters, and is separated from the ground storey by a deep eaves roof on corbelled brackets very similar in effect to the deep eaves of the Bijapur buildings. The roof, however, is of the Hindu pyramidal stepped variety. This appears to be a late building (c.983/1575?).

Outside the zanana enclosure is a long oblong building with eleven tall arched openings alternating with walls of blind arches, generally known as the 'elephant stables', but which E.B. Havell (Indian architecture..., London 1927, specially 185-92) takes to be the mosque built by Devarāya II (A.D. 1422-46) for his Muslim troops. The arched chambers are domed, and the central chamber is surmounted by a square turret, probably originally crowned by a stepped tower of the Hindu pattern, approached by steps from within. However, since the building faces west not east, as would be required in a mosque, this identification can be discounted [editor]. Another structure identified by A.H. Longhurst (Hampi ruins described and illustrated, Madras 1917) as 'Devarāya's mosque' is that in the 'army commander's enclosure'; but this building faces due north (the qibla here being slightly north of west) and the identification also may be rejected.

Near the 'elephant stables' is an oblong arcaded building called a 'guard-room' by Longhurst and 'Rām Rāj's treasury' by Havell; it has also been known as the 'concert hall'. This shows the best use of the structural arch in the Hampi buildings: foliated arches with radiating 
brick voussoirs, supported on slender columns; the roof is incomplete. Its purpose cannot now be known, but it obviously reflects work by Muslim craftsmen.

Other buildings of Muslim style at Hampi include some of the constructions associated with the elaborate irrigation system, the relation of which with the irrigation systems of the Muslim cities of Bidar and Bijapur has not yet been ascertained. These include two baths - the hammām was another Muslim institution borrowed by these Hindu dynasties - and an octagonal pavilion with fountains. About $1.8 \mathrm{~km}$. to the west of the citadel stand two Muslim tombs whose style resembles that of the early Bahmanī period at Gulborga; nothing is known of the history of these tombs.

That the synthesized tradition of the Hampi buildings endured after the conquest of Vijayanagara by the Deccan Muslim confederacy at Talikota in $972 / 1565$ is shown by the palace of the last dynasty built twenty years after the conquest at their new capital of Chandragiri in southern Andhra Pradesh, some $370 \mathrm{~km}$. south-east of Hampi. This is a three-storeyed building with a façade $45 \mathrm{~m}$. wide, each storey showing a range of pointed arches; inside there are excellent pillared halls, the upper one of intersecting arches roofed by shallow domes (see R.F. Chisholm, The old palace of Chandragini, in IA, xii (1883), 295-6). The roof is crowned by seven pyramidal towers of the Hindu sikhara type.

\section{HANsI*}

A town situated in the Haryana, of which it was the old capital until supplanted by Hisar Firuza in 757/1356. It is known from inscriptions that it was occupied by the Tomārs and Chauhāns before the Muslim conquest, and was perhaps occupied from Kushāna times, in the 1st or 2 nd century A.D.: certainly the old fort, to the north-east of the present town, is an extensive tell representing an accumulation of many cultural layers. Hansi was already a major stronghold when Mas' $\bar{u} d$, son of Mahmūd of Ghazni, stormed this "virgin fortress" in the winter of 429/1037-8 (Abu 'l-Faḍl Bayhaḳī, Ta'rīkh-i Mas'üdī, Tehran 1324/1945, 533-4; Eng. tr. Elliot and Dowson, History of India ..., ii, 140), capturing

\footnotetext{
* "Hānsī," EI, III, 167-8.
} 
it at his second attempt. From that time Hansi became an important forward position in the Ghaznavids' Indian province, and we read of Mas' ūd's second son, Majdūd, who had been appointed governor of that province, spending the winter of 433/1041-2 at Hansi waiting his chance to launch an attack on Delhi. Two years later, however, the Delhi $r \bar{a} j \bar{a}$ Mahīpāl recaptured Hansi, and it was strengthened by him and subsequent builders. Towards the end of the next century it was enlarged and further strengthened by Prithvīrāja as a bulwark against the Ghūri forces; but, after the defeat of the Hindu forces at Tarawari by Muhammad b. Sām, Hansi also surrendered (588/1192). At the end of that year a Chauhān army invaded Haryana, compelling the Muslim governor Nuṣrat al-Dīn to take refuge in the fort; but they were overcome by Quṭb al-Dīn Aybak (details incorrect in Wolseley Haig, CHI, iii, 41, cf. Hodivala, Studies in Indo-Muslim history, i, Bombay 1939, 179-80). Within a few months Aybak had taken Delhi, and made it the headquarters of Muslim power in India; the Muslim hold on Hansi thereafter remained secure.

Hansi frequently figures in the chronicles of the Delhi Sultanate both as an important stronghold and as an $i q t \bar{a} \bar{a}^{`}$ of numerous officials: doubtless a convenient one for the sultān to have at his disposal, for it was far enough from Delhi to make appointment - or banishment - to it a reality, but it was sufficiently close to the power of arms at the capital to prevent a rebel from easily asserting his independence. For example, it was the $i q t \bar{a}$ ' of Ghiyāth al-Dīn Balban in about 640/1242, to which he was banished in 650/1252-3 after the conspiracy against him; when he had gathered some local support there he was sent further, to Nagaur, and Hansi was nominally given to an infant son of the king but in practice was occupied by one of Balban's opponents (Minhāj-i Sirāj Juzjānī, Tabakātti Nāṣiñ, ed. Bibl. Ind. 202; Eng. tr. Raverty, ii, 140); other princes had held this $i q t \bar{a}^{`}$ previously, for example Abu'lFath Mahmūd, the son of Iletmish, who died in 626/1229, held Hansi before 623/1226 (Tabakāt-i Nāsinì, 180) and there built the $\bar{\imath} d g \bar{a} h$ (no date; inscription in J. Horovitz, in EIM, 1911-12, 28 and Pls. XIX/1, 2). The prestige of Hansi declined after the foundation of Hisar Firuza by Fīrūz Shāh Tughluq in 757/1356, which took over the function of headquarters of a shiqq; in the previous reign, however, Hansi had been described by Ibn Batțūta as "an exceedingly fine, well-built and populous city". It certainly remained in operation as a stronghold for some time, for in 923/1517 Ibrāhīm Lōdī confined his brothers there to keep his kingdom secure while he was faced with a rebellion at Jaunpur. 
Hansi itself is little mentioned during Mughal times; it appears in the $\bar{A}^{\prime} \bar{\imath} n-i$ Akbari merely as a mahall in the sarkār of Hisar Firuza in the șüba of Delhi. For a period Hansi became the headquarters of the English adventurer George Thomas. Thomas is said to have re-fortified Hansi; certainly a military fort was established there by the British in 1803, and one Mīrzā Ilyās Beg was appointed nāzim of Haryana by General Ochterlony; but the country remained subject to constant raids and was for long in disorder until the British established direct rule over the region in 1818.

\section{Monuments}

The old fort has already been mentioned; it was dismantled after the mutiny of 1857, but gateways and lengths of bastioned wall remain. The dargāh of Sayyid Shāh Ni'mat Allāh, who accompanied Muhammad b. Sām in 588/1192 and was killed at the conquest of Hansi, stands in the fort; Hindu materials were freely used in its construction, and if the date 588/1192 in the inscription of the attached mosque is correct it must be the oldest mosque in India (some doubt this; cf. Horovitz, op. cit., 19). On the west of the town stand the mosque and tomb of the "four Quṭbs", Quṭb Jamāl Dīn Hānsavī and his three successors; the shrine itself was not built until 903/1496, but in a mosque in the enclosure is a tombstone with an Arabic inscription of $1 \mathrm{Dhu}$ 'l-Ka'da $622 / 4$ November 1225, the oldest dated tombstone in India; another mosque nearby bears the date Muharram 877/June 1472; and in the same enclosure is the tomb of 'Alī Mīr Tujjār (sic; the word is used as a singular in Urdū), a disciple of Quṭb Jamāl Dīn. This is the finest building in Hansi, a square domed mausoleum with glazed tiles in inlaid patterns in the spandrels of the openings and filling the small blind arches above the level of the doors; it appears to date from the 15th century, although the local tradition assigns it to the 13th. Also to the west of the town is the $\bar{\imath} d g \bar{a} h$ already referred to. Further still is a mound, with a small mosque, called the Shahīd Ganj, traditionally supposed to be where 150,000 Muslims were slain, presumably in Mas'ūd's first unsuccessful attempt on Hansi. 


\section{HYDERABAD*}

The site of the present city of Hyderabad was selected in 997/1589 by the fifth Quṭb Shāhī dynast, Muhammad Qulī Quṭb Shāh, on the right bank of the river Musa, a tributary of the Krishna, some 5 $\mathrm{km}$. east of the fortress of Golkonda, and at first given the name of Bhāgnagar after a Hindu dancing-girl named Bhāgmatī, one of the sultān's concubines. A city quickly grew up on this site, since there was no room for expansion in the overcrowded Golkonda where, moreover, the water-supply was inadequate. The exact date of the transfer of the seat of government from Golkonda to Hyderabad is not known, although this seems to have taken place within a dozen years of the foundation; Hyderabad was not at first fortified, Golkonda remaining as the citadel of the capital. At this time North India was in the hands of the Mughals, and envoys from Akbar were well received in 999/1591; the Quṭb Shāhī sulțān sent valuable presents to Akbar which were accepted as tribute, and his domains were left unmolested. The new city prospered, some of its finest buildings dating from this time (see below), until the intervention of the Mughal prince (later the emperor) Aurangzīb in the dispute between Mīr Jumla and 'Abd Allāh Quṭb Shāh in 1065/1655 when Hyderabad was plundered before the sultān bought peace; but the peace was uneasy, and Hyderabad again fell to the Mughals under Aurangzīb four years before the great siege of Golkonda in 1098/1687. After the conquest Hyderabad became the residence of the sübadārs of the Deccan, under the last of whom, Chīn Qilich Khān, Nizāam al-Mulk, the governor Mubariz Khān commenced the fortification of the city by a stone wall. After the important and decisive battle of Shakarkhelda in 1137/1724, by which the Niẓām alMulk crushed the plan of his deputy Mubāriz Khān to usurp power in the province, Hyderabad became the capital of the now independent Deccan province under the Nizām al-Mulk, who received the title of Āṣaf Jāh from the Mughal emperor Muhammad Shāh; the titles Nizạam al-Mulk and Āṣaf Jāh henceforth became hereditary in his family. The political history of the city thereafter is little different from that of the state.

\footnotetext{
* "Haydarābād, a. Haydarābād city," EI, III, 318-23.
} 


\section{Monuments}

The old city is surrounded by a bastioned wall, completed by the first Așaf Jāh, with thirteen gates and a number of smaller posterns. The city is connected to the northern suburbs by four bridges, the oldest of which (Purānā Pul) was built by Muhammad Qulī Quṭb Shāh in $1001 / 1593$. The same ruler was responsible for the buildings in the central focal point of the city, notably the Chār Mīnār, Chār Kamān, Chār sū kā Hauz, all around a crossing of four roads leading to the four quarters of the old city; also the Dār al-shifā', 'Āshūr-khāna, and Jāmi' Masjid. The Chār Mīnār, 'four minarets', is a triumphal archway, $30 \mathrm{~m}$. square in plan, its ground storey consisting of four great arches of $10.8 \mathrm{~m}$. span, each facing a cardinal point; above this is an arcaded triforium running round the building supported on carved corbels, with a smaller arcade and a perforated marble screen above it; at each corner stands a minaret $55.8 \mathrm{~m}$. in height from the ground level, each decorated with a double arcaded balcony at the level of the triforium supported by a continuation of the corbel course; a further single arcaded balcony encircles each shaft above roof-level (this is the characteristic feature of the Quṭb Shāhī architecture); and each minaret is topped by yet another such balcony supporting a round kiosk with an ogee dome foliated at its base in the Bijapur manner. The small rooms inside the upper storey are said to have been used for instruction by shaykhs; but, from the strictly ceremonial and royal nature of the use of this building under the Quṭb Shāhīs and Āṣaf Jāhīs, this story may be doubted. (See ARADHS, 1917-18, Pl. IIa; ibid., 1918-19, 3-4 and plans on Pls. III-IV.) The Chār Kamān, 'four bows', (ARADHS, 1918-19, 4), are four wide arches near the Chār Mīnār built over the four roads leading to the four quarters of the city, near to which stands the Chār sū kā Hauz, 'carfax cistern'; near this once stood Muhammad Qulī’s Dād Mahall, 'palace of justice', destroyed by a powder explosion in 1771 (described by the French traveller Tavernier in 1062/1652). West of this complex is the Makka Masjid, the principal mosque of the city, commenced by 'Abd Allāh Quṭb Shāh, continued by his successor Abu'lHasan, the last Quṭb Shāhī sulțān, and completed at Aurangzīb's order; the liwwan, with two large domes, is $67.5 \mathrm{~m}$. long and $54 \mathrm{~m}$. deep, standing behind a vast șahn $108 \mathrm{~m}$. square; the tombs of Niẓām 'Alī Khān and later Āṣaf Jāhīs stand in the mosque. The old remains of a contemporary hammām stand in its courtyard. In the north of the old city is the 'Āshūr-khāna, 'room of the tenth [of Muharram]', still in 
use for the Muharram ceremonies, with fine Persian faience decorating its walls. The Dār al-shifā', also built by Muhammad Qulī Quṭb Shāh, is in the north-east quarter of the city, a large building with arcaded chambers for the care of the sick, lying all round a paved quadrangle, formerly in use also as a school for the Yūnānī system of medicine; a mosque, built at the same time, stands opposite its entrance. Many other buildings of Quṭb Shāhī times stand in the city and suburbs, notably the Tolī Masjid of the time of 'Abd Allāh Quṭb Shāh (inscription in mihrrāb giving date of 1082/1671 by abjad); description in ARADHS, 1916-17, 3 ff. Pls. IIb and c, plan on Pl. IIIa; also the mosque and other buildings of the Shaykhpet suburb, see ARADHS, 1936-37, 2 ff., with an inscription of 1043/1633, cf. EIM, 1935-6, 21-2 and Pl. XIII.

Between Hyderabad and Golkonda, on the 'Uthmān Sāgar road, surmounting two small hills, are the bāradar̄ of Tārāmatī, a Hindu concubine of Muhammad Qulī Quṭb Shāh, and the elegant but incomplete (no minarets) mosque of 'Pēmmatī', d. 1073/1662, for which see ARADHS, 1924-25, 2-4 and Pls. III-VI. Of the other Quṭb Shāhī monuments the Gosha Mahall stands north of the old city, a palace built by the last sultan with an extensive pleasure-park for the zanāna and an ornamental tank, now dry and used for football matches. The Dā'ira-yi Mīr Mu'min is a burial ground east of the city consecrated by a Shīi saint who came to Hyderabad from Karbala in the reign of 'Abd Allāh Quṭb Shāh; the cemetery, now used for Sunn̄̄s as well as Shî‘as, contains many fine tombs and gravestones, including the fine domed tomb of the Mīr himself in Quṭb Shāhī style.

There are also in and around Hyderabad many palaces and other buildings of the Āṣaf Jāh dynasty, from the Purānī Havelī of the first Nizām, the Chaumahalla palace in the centre of the city which was the principal city residence of the Nizāams, modelled on a royal palace in Tehran, the palace of Sir Salar Jung once used as a museum, but now demolished, to the late 19th century Falaknumā palace outside the city on the south-west, with a Palladian façade, Louis XIV reception hall, and other exotic features.

The city water supply depends on tanks, to which modern waterworks are now attached, excavated in former times. The Husayn Sāgar, about 2,100 hectares., lies between Hyderabad and Sikandarabād (Secunderabad), the road between the two cities running along the bund on its east; it was originally excavated by Ibrāhīm Quṭb Shāh in 983/1575 as a reservoir for Golkonda and was filled by a channel cut from the Musi. South-west of the city is the Mīr 'Ālam tank, built by French 
engineers in the Nizâm's service early in the 19th century, while the Mīr Jumla tank to the south-east, now no longer used, was constructed in $1035 / 1625$.

Of European monuments the old British Residency of 1803-8, now a women's college, and the tomb of the French soldier M. (Michel Joachim Marie) Raymond (corrupted locally to 'Mūsā Rahīmm'!), d. 25 March 1798, are worthy of notice.

\section{JALOR*}

A town in Rajasthan, some $120 \mathrm{~km}$. south of Jodhpur on the left bank of the Sukri river.

Although the troops of 'Alä' al-Dīn Khaljī had passed through Jalor on their return from the conquest of Gujarat in 696/1297, it was not then occupied by them. In Jumādā I 705/December1305, however, that sultān sent 'Ayn al-Mulk, governor of Multan, on an expedition to Jalor, Ujjayn and Chanderi; he was opposed by an army of 150,000 Hindus on his entry into Malwa, and his victory over them, which brought Ujjain, Dhar, Mandu, and Chanderi into Muslim possession, so impressed the Chauhān rāja of Jalor that he accompanied 'Ayn al-Mulk to Delhi to swear his allegiance to 'Alā' al-Dīn. Two years later this rājā's arrogance caused 'Alä' al-Dīn to attack Jalor, which was taken for Delhi by Kamāl Dīn Gurg. On the weakening of the sultanate at 'Alä' al-Dīn's death it seems to have relapsed into Chauhān possession.

At some time in the 14th century a body of Lohānī Afghāns left their adoptive province of Bihar and came to Marwar, where they entered the service of the Chauhān rāja of Jalor. On the latter's death by a trick at the hands of a neighbouring rāja in 794/1392 their leader, Malik Khurram, assisted the rāja $\bar{a}$ s widow in carrying on the government, but after disagreements between the Afghāns and the Rājpūts he established himself as ruler over the city and its fort, Songir (Sanskrit: suvarna-giri, "golden hill"), and sought through Zafar Khān, șübadār of Gujarat under the Tughluqs, a farmān from Delhi confirming his title; this was given, 796/1394. After Tīmūr's depredations in North India in 801/1399 the Jālorīs became independent rulers for a time, before later becoming feudatory to the new and powerful sultanate of Gujarat.

* “Djālor,” EI, II, 405. 
At some time in the early 16 th century the Jālorī family had added Palanpur to its dominions, and by mid-century its ruler had acquired the title of Nawwāb. By about 1110/1699 the Nawwāb moved his seat from Jalor to Palanpur, which remained an independent Muslim state until 1956.

\section{Monuments}

The fort of Jalor was built by the Paramāra Rājpūts, and remained substantially unchanged under Muslim rule except for the modification of its perimeter wall for artillery. The oldest monument is the mosque in the city, built from temple spoil probably at the time of 'Alā' al-Dīn, $56.4 \mathrm{~m}$. square, with cloisters of three arcades on north, south, and east, broken by doorways, and a deeper three-domed lizwan on the west. The latter is faced with a screen wall of later date, probably of the time of Muzaffar II of Gujarat (917-32/1511-26); an inscription including the name of Muhammad b. Tughluq stands over the north door, implying an extension or restoration in his time. The arcades have been enriched by the addition of graceful and delicate stone lattice screens of the middle Gujarati period. Known as the Tōpkhāna Masjid, it was for long used as an arsenal. A smaller mosque stands in the fort; although said by Erskine (Rajputana Gazetteer, iii A, 1909, 189 ff.) to have been built by 'Alā' al-Dīn's armies, it seems to be in its present form entirely a construction of the period of Mạmmūd Shāh 'Begrā' (863-917/14581511) or Muzaffar II of Gujarat, and bears an inscription of the latter.

\section{JAUNPUR*}

This city on the Gumti river in Uttar Pradesh, was founded in 760/1359 by Fīrūz Shāh Tughluq, near the ancient Manaych reduced by Maḥmūd of Ghazni in 409/1018 and renamed Zafarabad by Zafar Khān, its governor under Ghiyāth Dīn Tughluq after 721/1321. Muslim historians derive the name Jaunpur from Jauna Shāh, Muhammad b. Tughluq's title before his accession; but Jamanpur is known as a by-form of the name $($ ? connexion with Jaun = Yamuna; Skanskrit Yamunendrapura has been suggested as the etymon), and this origin cannot be regarded as established.

\footnotetext{
* "Djawnpur," EI, II, 498-9.
} 
In the confused conditions at the beginning of the reign of Nāṣir alDīn Mahmūd Tughluq the disaffected Hindus of the eastern provinces rejected all obedience to Delhi. The eunuch Malik Sarwar, Khwāja Jahān, persuaded Maḥmūd to grant him the title of Sulțān al-Sharq and send him to crush the rebellion in 796/1394; having brought under control Koyl, Etawa and Kanauj he occupied Jaunpur, and there established himself as independent ruler of a kingdom extending over Awadh, west to Koyl and east into Tirhut and Bihar; to these lands were later added the Chunar District (857/1453) and Rohilkhand (870/1466). In 884/1479 Bahlōl, the first Lōdī sultān of Delhi, defeated the last Sharqī sultān, Husayn, and established his son Bārbak as ruler over Jaunpur with permission to use the royal title and to issue coin. After Sikandar overcame his brother Bārbak as sulțān of Delhi in 894/1489 Jaunpur was absorbed in the Delhi Sultanate.

In 933/1526-7 Jaunpur was taken for his father Bābur by Humāyūn, and a governor was appointed; but the growth of the power of Sherr Khān (Shēr Shāh Sūrī) and the disaffection of the Afghān faction on the death of Junayd Birlās, the governor, compelled Humāyūn to march again on Jaunpur in 943/1536, with success; but Humāyūn's long absence from Delhi lost him his hold on the eastern provinces, and even before his great victory of Muharram 947/May 1540 Shēr Shāh was in command, with his son 'Ādil Khān installed as viceroy in Jaunpur. The importance of Jaunpur declined with the rise of Chunar, and not until the rebellion (970/1563 onwards) of 'Alī Qulī Khān, governor since 965/1558, does it again come into prominence; 'Alī's final defeat in Dhu 'l-Hijja 974/June 1567 led to Akbar's temporary residence there and the governorship of Khān-i Khānān Muhammad Mun im Khān. After the foundation of Allahabad the importance of Jaunpur waned; it passed into the possession of the Nawwābs of Awadh in the early 18th century, and into British hands in 1775.

Jaunpur was long celebrated for its learning, "the Shirāz of Hind", from its foundation by Fīrūz certainly until the time of Shēr Shāh; some of its rulers - notably Ibrāhīm and Husayn - were cultured connoisseurs of more than mere scholastic learning; Qur'ān schools still exist within the precincts of the mosques.

\section{Monuments}

The fort of Fīrūz Shāh, an irregular quadrilateral on the north bank of the Gumti, is of high stone walls built largely from local temple spoil, 
with a single gateway protected by tapering semicircular bastions; other bastions were destroyed in 1859 by the British, as were some of the internal buildings, including the palace built by Fīrūz Shāh's governor, the Chihil Sutūn (illustration in M. Kittoe, Illustrations of Indian architecture..., Calcutta 1838). The fort mosque of the same governor, Ibrāhīm Nā'ib Bārbak, still stands: the side tīwāns are low, trabeate, supported on rows of pillars from Hindu temples set up at random; there are many additions of later periods (see Kittoe, op. cit.); a detached min̄ār in the courtyard, some $12 \mathrm{~m}$. high, has a fine Arabic inscription giving its date as Dhu 'l-Qa'da 778/March-April 1377. A small detached pillar within the fort proclaims an edict of Așaf al-Daula of Awadh on the continuance of the daily stipend to indigent sayyids (sādāt bi-nawä) from the revenues of Jaunpur (1180/1766).

The Atalā mosque, whose foundations were prepared on the site of the Hindu temple to Atalā Devī by Fìrūz Shāh Tughluq, was not built until 810/1408 under Ibrāhīm Sharqī; its main feature, the central bay of the west hiwann covered by a large dome which is concealed from the courtyard by a tall pyramidal gateway resembling the Egyptian propylon, is the special characteristic of the Jaunpur style under the Sharqī sultāns. The Atalā mosque is the largest $(78.7 \mathrm{~m}$. square) and most ornate: the liwwans on north, east and south are composed of five pillared aisles in two storeys, the two outer aisles at ground level being formed into a range of pillared cells facing the streets; in the middle of each side is an archway, with a smaller propylon on the outside, and with domes over the north and south gates; a dome covers the central bay of each tiweran on the north and south of the main dome, each with its propylon facing the courtyard. Within each propylon is a large arched recess, with a fringe of stylized spearheads similar to those of the Khaljī buildings at Delhi, in which are pierced arched openings in front of the dome, and the main entrances beneath. The main propylon is $22.9 \mathrm{~m}$. high, the dome behind being only $19.5 \mathrm{~m}$. high, and 16.8 $\mathrm{m}$. wide at its base. The dome is supported on a sixteen-sided arched triforium, on corner brackets over an octagon with pierced windows, supported on squinch arches. The qibla wall is relieved on its exterior by square projections behind each dome, the corners of each supported by a tapering buttress; larger tapering buttresses support the main angles of the wall. There are no minārs, the top storeys of the propylon serving for the mu'adhdhin.

The Masjid Khāliṣ Mukhliṣ, built by two governors of Ibrāhīm, is of the same period, only the central propylon and dome and western tiwe ans 
remaining, all massive and without ornament. Of the contemporary Jhanjharī (jhanjhhar, "perforated") mosque only the screen of the central propylon remains, filled with the finest stone tracery in Jaunpur. The Lāl Darwāza ("red gate"; near the gate of a former palace) mosque in the north-west of the city, the smallest of the Jaunpur mosques, was built c. 851/1447, the sole surviving monument of the reign of Mahmūd Sharqī, has a single central dome and propylon with tall trabeate transepts, and zanāna galleries on a mezzanine floor flanking the central bay. The foundation of the Jāmi' Masjid was laid in 842/1438, but it was not finished until the reign of Husayn. The mosque stands on a raised terrace 5 to $6 \mathrm{~m}$. above street level, with a single propylon in the west liwwan, the transepts covered by fine barrel-vaults, and the façade entirely arcuate. These are the only remains of the Sharqīs standing at Jaunpur, the rest having been demolished by Sikandar Lōdī; all are of stone, largely pillaged from Hindu or Buddhist temples, and cement, the work of Hindu craftsmen. Echoes of the characteristic style of the capital occur in other places within the quondam Jaunpur kingdom, in the Arha' $\overline{1}$ Kangura Masjid at Banaras (Varanasi), and in the Jāmi ${ }^{\complement}$ Masjids at Etawa and Kanauj.

By far the most significant monument of Mughal times is the great bridge of Mun im Khān, begun 972/1564 and finished 976/1568, traversing the Gumti. Built by Afghan workmen under a Kabul architect, Afzal 'Alī, it consists of ten spans of arches - the four central ones of wider span than those at each end - the very massive piers of which carry pillared and screened pavilions at road level, partly projecting over the water on brackets; a further five spans carry the road over a smaller branch of the Gumti.

In the old town of Zafarabad, $6.5 \mathrm{~km}$. south-east of Jaunpur, is the mosque of one Shaykh Bārha, converted c. 711/1311 from Buddhist temple remains, entirely trabeate though originally with a large central arch between two piers, which was probably the prototype of the propylons of the Jaunpur mosques. There are also many tombs, the most noteworthy being those of Makhdūm Șāhib Chirāgh-i Hind (781/1389) and Sayyid Murtazā in the dargāh-i shahād, the burial ground of the martyrs who fell in the invasion of Shihāb al-Dīn Shūrī in 590/1194. 
KALPI*

Once a powerful town in Uttar Pradesh, the old town and fort of Kalpi stand on clay cliffs overlooking the river Yamuna; there is a modern town to the south-east of the old one, which has some commercial importance and where a fine quality paper is still made by hand. The town was traditionally founded by a rāja of Kanauj in the 4th century, and fell into Muslim hands in the first conquest in 593/1196. The high fort, walled on three sides and defended on the fourth side by the cliffs and river, was an important stronghold on the Dehli sultāns' line of communication along the Yamuna. In the early 15th century, after Tīmūr's devastation of Delhi, Kalpi became independent for a short time under a former governor, Muḥammad Khān b. Malikzāda Fìrūz, until in 837/1433-4 Ibrāhīm Shāh of Jaunpur sought to annex it to the Sharqī Sultanate; a counter-attack by Mubārak Shāh Sayyid of Delhi regained it, but in the following year during the Delhi-Jaunpur wars it was seized by Hūshang Shāh Ghūrī of Malwa and remained in the possession of Malwa for the next ten years. About 847/1443 it was sacked by Mahmūd of Jaunpur, but after the eventual fall of the Sharqī Sultanate to Bahlūl Lōdī, Kalpi reverted to Delhi, and Bahlūl appointed Quṭb Khān Lōdī as its governor. There were in addition several minor incidents during the 15th century in which possession of Kalpi fluctuated between Delhi, Jaunpur and Malwa. It fell into Mughal hands in 933/1527, and under Akbar served as the headquarters of a sarkār and a copper mint. After the Marāthā wars in the early 18th century Kalpi became the residence of a Marāthā governor.

\section{Monuments}

Among a number of old Muslim tombs to the west of the old town, one is outstanding, the Chaurāsī Gunbad (lit. "84 domes"; this name is obscure). This is a square, nine-domed structure in a walled courtyard, with two graves under the central dome; popular belief assigns it to a Lōdī sultân; it is possible that it may have been of a Lōdī governor, as the style of its arches and the supporting systems is consistent with a late 15th or early 16th century date; certain Jaunpuri motifs in its decoration do not necessarily vitiate this conclusion, as stonemasons

\footnotetext{
* "Kalpī," EI, IV, 513.
} 
would have had no difficulty in travelling from one area to another on the Yamuna. It is possible that the " 84 " of its name represents a date; if so 1584 V.S., about $934 / 1527-8$, would be the most likely.

\section{KALYANI*}

In the 10th and 11th centuries this fortified town of the Deccan, about $60 \mathrm{~km}$. west of Bidar, was the capital of the Late Chālukya rājass, passing later to the Yādavas of Devagiri (= Daulatabad); after the foundation of the Bahmanī dynasty at Devagiri, Kalyani was annexed as one of the strongholds on their northern borders; but there had presumably been a previous Muslim conquest of the town since an inscription is preserved of a Jāmi` Masjid by Ulugh Khān (later succeeded as Muhammad b. Tughluq) in 723/1323; and another Tughluq inscription of 734/1333 is known. The fort was rebuilt by the Bahmanis at the end of the 15th century after the introduction of gunpowder. The fort was maintained in good repair, as is evident from a series of inscriptions on its bastions, in the 16th century; these show that it was held by the Barīd Shāhīs as the successors to the Bahmanīs in Bidar until 981/1573, after which it passed to the 'Ādil Shāhīs of Bijapur. It fell to the Mughal empire, after a protracted siege by Aurangzīb, in 1067/1657, and was included in the Mughal süba of Bidar. When the Deccan became independent of the Mughals under the first Niz̄ām of Hyderabad, Kalyani was one of the possessions included. From 1178/1764 it was governed by a line of Nawwābs of Kalyani, of whom the first was Mīr Muhammad Ibrāhīm Khān, a son-in-law of Āṣaf Jāh of Hyderabad.

An architectural survey of the fort and its monuments is awaited [editor].

\section{KANAUJ**}

This town in Uttar Pradesh takes its name from the Sanskrit Kanakubja, but was known to the Arabic geographers as Qannauj, Qinnauj, the latter form used also in Hudüd al-'Álam. It has been identified, not beyond question, with Ptolemy's Kóv $\alpha \gamma o \rho \alpha-\mathrm{K} \alpha \dot{v} \alpha \gamma_{0} \zeta \alpha$; it is certainly

* "Kalyani," EI, IV, 513-4.

** "Kanawdj," EI, IV, 533-4; co-authored with M. Longworth Dames. 
referred to in the travels of Fa Hsien (A.D. 405) as a city under the Guptas, and as a capital and great Buddhist centre at the time of Hsüan Ts'ang's travels, c. A.D. 641, when under the great Harșavardhana it had become the chief town of the Panchāla country. As the capital of the Gurjara-Pratihāra dynasty (Hudūd al-'̄Alam, s.v. Jurz) it exercised strong control over North and North-west India from the Sutlej river to Bihar, bordered on the west by Sindh; and it is presumably against this "kingdom" of Kanauj rather than against the town that Muhammad b. Qāsim, the conqueror of Sindh, is alleged by the Chach-nāma to have made war. At the time of the Ghaznavid invasions of the 12th century, when North India was ruled over by numerous petty kingdoms, the Kanauj region was under the Gāhadavāla Rājpūts; together with Malwa, Kalinjar, Dahgan and Badaun, Kanauj bore the brunt of the Ghaznavid attacks (Mas'ūd Sa'd Salmān, Dì̌wān, 28, 219, 247, 262-65, 307, 397). Muslim colonies at Kanauj and these other places seem to have existed from the times of these incursions. Under the Ghürids the Gāhadavāla power was at first a formidable opponent, and Kanauj was not annexed to the early Delhi Sultanate until 595/1198-9; the hold seems to have been insecure, for it was necessary for Iletmish to attack it again later - presumably decisively, for a few years later we find his young grandson 'Alā' al-Dīn Mas'ūd appointing a cousin, Jalāl Dīn, to the governorship of Kanauj in 640/1243. Thereafter it figures frequently in the histories of Khalji and Tughluq times, doubtless on account of its strategic importance on the banks of the Ganga; Ibn Batțuața refers to it as well built and strongly fortified, and mentions its sugar trade. Kanauj figures as one of 23 provinces in the time of Muhammad b. Tughluq (Masālik al-Absār, Eng. tr. Spies, Aligarh 1943, 16).

Towards the end of the 14th century Kanauj was one of the centres of activity of the Hindu "rebels" against whom Malik Sarwar was despatched in 796/1394; and, in his new governorship which was soon to become the sultanate of Jaunpur, he was in charge of a region extending from Kanauj to Bihar. When the Sultanat al-sharq achieved independence from Delhi, Kanauj, as its westernmost stronghold, was often a point of contention between the sultanates of Delhi and Jaunpur, and there were many battles in its vicinity. The town was taken by Mahmūd Tughluq in 804/1401-2, who held it as his temporary capital (probably with the connivance of the Sharqī ruler) against his recalcitrant wazìr Mallū Iḳbāl Khān Lōdī; after the death of the latter it was recovered by the Sharqīs in 809/1407 (Tảrīkh-i Mubārak Shāhī, 175). It again figured in 
the Delhi-Jaunpur conflicts at the time of Bahlūl Lōdī versus Husayn Shāh Sharqī, and Sikandar Lōdī versus his brother Bārbak.

Humāyūn took Kanauj for his father Bābur in the campaigns of 932/1526, only to lose it, and his kingdom, to Shēr Shāh fourteen years later. After the Mughal restoration the history of Kanauj seems to have been largely peaceful, and the $\bar{A} ' \bar{n}-i A k b a r \bar{\imath}$ records it as the headquarters town of sarkār. In the 18th century, with the decline of the Mughal power, Kanauj was variously in the hands of the Nawwābs of Farrukhabad, the Nawwābs of Awadh, and occasionally the Marāthās.

Kanauj appears as a mint town, Kanauj urf Shargarh, under Shēr Shāh and the later Sūrīs; its name was changed by Akbar to Shahgarh, although under the later Mughals it appears as Shahabad.

\section{Monuments}

These are poorly described, although there are many tombs and shrines in the neighbourhood. The Jāmi' mosque, built by Ibrāhīm Sharqī, using much Hindu and Jain temple spoil, shows the westernmost extension of the Sharqī style.

\section{KANDAHAR*}

Kandahar in the Deccan, locally often spelt Kandhar or Kandhar to distinguish it from its illustrious Afghan namesake, is a plains fort $40 \mathrm{~km}$. south-west of Nanded. It and the surrounding ta'alluq, mainly agricultural, are known to have been part of the Bahmanī dominions, from whom it later passed to the 'Ādil Shāhīs. It seems, however, to have known previous Muslim occupation, since the main gate bears an inscription of Muhammad b. Tughluq (EIM, 1919-20, 16-7) and was presumably occupied by him on his expedition to South India.

\section{Monuments}

Kandahar fort is remarkable for its highly developed military architecture, which shows, successively from the exterior, a large glacis with a retaining wall, a covered way, a moat 2 to $3 \mathrm{~m}$. deep and 21 to $24 \mathrm{~m}$.

\footnotetext{
* “Kandahar,” EI, IV, 538.
} 
wide, a massive fausse-braye, built in large dressed masonry by Muslims out of Hindu materials, with defensive bastions at intervals, a second covered way, and the main ramparts of the enceinte with strong towers and bastions. Across the moat is a single drawbridge leading to a series of gateways, of which the first, the Jinsī or Lohābandī Darwāza, facing north, is protected with steel plates and defended by a bastion; a barbican court leads to the main gate, the Makka or Macchlī Darwāza, facing west. An inner court connects with the second covered way and leads to the third (Mānkalī) gate, flanked with high bastions, before the interior of the fort is reached. A Jāmi Masjid of the late Bijapuri style stands inside the final inner court. Many of the bastions of the enceinte bear guns, and some have inscriptions showing their construction by "Āqā Rūmī”, presumably a Turkish engineer, of dates near 998/1590.

\section{MAHUR*}

This small town in the extreme north of the former Hyderabad State is situated just to the south of the Penganga river, a left-bank affluent of the Godavari, where it forms the boundary between the former regions of northern Hyderabad and Berar in Central India.

In pre-Muslim times, Mahur had the shrine of Śrī-Dattātreya. In the middle years of the 14th century, the territory up to Mahur was conquered by the Deccani power of the Bahmanīs. In 857/1453 Mahmūd I Khaljī of Malwa besieged the fortress of Mahur, but was unable to conquer it from the Bahmanīs, and in 872/1468 it was again a bone of contention between the two powers. In later times, however, it relapsed into insignificance. In British Indian times, it fell after 1905 within the Adilabad District and ta'alluq, but is now in Nanded District and Kinvat táalluq.

\section{Monuments}

Mahur has an important fortress, which may have been in existence in pre-Bahmanī times. It stands on a steep hill $120 \mathrm{~m}$. above the valley of the Penganga, and is irregularly shaped since it occupies the edges of two adjacent spurs (the intermediate valley is converted into

* "Māhūr," EI, VI, 87; co-authored with C.E. Bosworth. 
a large tank through the construction of a massive connecting wall); the hill is precipitous on the east, south and west, its northern access being defended by multiple gateways. The main northern gateway (known as Chīnī Darwāza, from the panels of Bahmanī tilework on its façade) encloses a defended entry with guard rooms along each side; the qil'adār's residence is set in an upper storey.

\section{MANER*}

This former town, now no bigger than a village, $32 \mathrm{~km}$. west of Patna in Bihar, is located by the junction of the rivers Son and Ganga (it was reported to be at the junction in $1722,5 \mathrm{~km}$. south of it by 1812 , $10 \mathrm{~km}$. south by 1907); it had therefore some strategic and mercantile advantage, and was one of the earliest and most important sites of Muslim colonisation in this part of India.

By Mughal times, Maner had become the chief town of a pargana of some 80,000 bìghas in the șüba of Bihar $\left(\bar{A}^{\prime} \bar{\imath} n-i\right.$ Akbarì, tr. Jarrett, Calcutta 1891, ii, 151, 153). A copperplate grant from a Hindu king of Kanauj (ed. and tr. R. Sarma, in FBORS, ii/4 [1916], 437-40) of A.D. 1126 requires its Brāhman recipient in "Maniyāra" to pay the tax called turushka danda "Turk's duty", which seems to imply that tribute was being paid some 70 years before the Muslim conquest of North India, presumably to a Ghaznavid agent; the early date is strengthened by local tradition, which holds one grave in the great dargāh to be that of Tāj al-Dīn Khandgāh, the nephew of Mạmmūd of Ghazni (local traditions in Eastern India may refer to other putative kinsmen of the Ghaznavid rulers; but other early 12th century Sanskrit inscriptions also mention the turushka-dana, and references in Bayhakī point to sporadic trans-Gangetic Muslim settlement; see K.A. Nizami, Some aspects of religion and politics in India during the thirteenth century, Bombay etc. 1965, 76 ff.). The consolidation of Islam is, however, thus explained: a Yemeni saint Mu'min 'Ārif (still of great local repute) had settled in Maner, but was harassed by the local $r \bar{a} j \bar{a}$; he went back to Medina and returned with a raiding party led by Hazrat Tāj Faqīh, which defeated the local $r \bar{a} j \bar{a}$ in a pitched battle, destroyed the temple (chronogram, shud dinn-i Muhammad qaw $=576 / 1180$ ) and dismantled the riverside fort. Many

* "Manēr," EI, VI, 409-10. 
"shahìds' graves" in Maner are said to date from this time. Tāj Faqīh returned to Medina, leaving his kinsmen to rule Maner; but the rule seems to have been a spiritual one, for his grandson Shaykh Yahyā Manērī, d. 690/1291 (chronogram: makhdūm!), was the most celebrated saint of Bihar, progenitor of a distinguished line of local saints, whose shrine (in the Barī Dargāh; see below) was visited by Sikandar Lōdī, Bābur, Humāyūn and Akbar, though his fame has been eclipsed by (and sometimes conflated with) that of his son Sharaf Dīn Ahmad Manērī of Bihar Sharif, murid of Najīb al-Dīn Firdausī. Eighth in descent from Shaykh Yahyā was Abū Yazīd, commonly known as Makhdūm Shāh Daulat, d. 1017/1608-9, whose tomb (the Chōtī Dargāh) is the finest Muslim building in Bihar.

\section{Monuments}

The khānqāh forms a complex of buildings disposed around a vast rectangular tank (hauz), its stepped masonry sides equipped centrally with ghāts and bāradarìs, drawing its water from the river Son by a subterranean channel. The tank is said to have been rebuilt in stone at the same time as the Barī and Chōtī Dargāhs were erected in the early 17th century by Ibrāhīm Khān Kākar (not by Ibrāhīm Khān Fatḥ Jang, șübadār of Bihār 1023-5/1615-17, as P. Horn, Muhammaden inscriptions from Bengal, EI, iii (1894), 280-96, and others assert). The Barī ("great") Dargāh west of the tank, on the site of the temple mound, is great in sanctity rather than magnificence. It consists of a great boundary wall enclosing a graveyard and a small mosque, standing to the west of a railed platform containing the simple open grave of Shaykh Yahyā (inscription of Ibrāhīm Khān Kākar, 1014/1605-6); also odd stone pillars, and a mutilated statue at the entrance presumably from the old temple. The Chōtī ('small') Dargāh is a high square platform in a fortress-like brick enclosure north of the tank, on which stands the square sandstone mausoleum of Makhdūm Shāh Daulat (inscription with decease chronogram 1017/1608-9, and two construction chronograms 1025/1616), a superb specimen of provincial Mughal architecture. The central square chamber is domed, with lower and upper verandahs (fine carved ceilings: floral, geometric and Qur'ānic designs) running round all sides, each corner formed into a square room with arched openings below and an open domed chhatri of similar size above. The lower verandah and the chhatris are built on the beam-and-bracket principle, and heavy stone corbels support both the lower and upper 
chhajj $\bar{a}$, contrasting with the arches of the tomb chamber which also has finely carved stone screen openings. A local tradition asserts that the stone was brought from Gujarat; certainly, features of Gujarati tomb design are apparent here. West of the mausoleum is a small mosque with curvilinear roof, centrally situated between stone verandahs running along the entire western wall of the enclosure; inscription dated 1028/1619, quoting Qur'ān, III, 97-8. An underground chamber in the south-west corner is identified as the chilla of Shāh Daulat. A fine entrance gate, in a more conventional Mughal style, bears two chronograms of 1022/1614-15 and 1032/1622-3. Other minor buildings around the tank are in grave disrepair.

The earliest inscription of Maner, 798/1395-6, records the reconstruction of an older mosque, now disappeared. The Jāmi ' Masjid of Maner, itself undistinguished, bears two records of renovations, of 1103/1691-2 and 1283/1866 (the last on a marble slab carved in Medina), both mosques thus testifying to a vigorous Muslim population over the centuries; but the grounds around the Maner tank are also the scene of a doubtfully Islamic fair on the urs of Ghāzī Miyān.

\section{MATHuRA*}

This Indian city (previously spelt as "Muttra") on the right bank of the Yamuna river between Delhi and Agra is of considerable antiquity and of high reputation as a place of high religious sanctity for Hindus and, formerly, for Jains and Buddhists also; it was already a place of some renown when it became the eastern of the two Kushāna capitals.

Surprisingly, Mathura is not mentioned in the Hudüd al-'alam, and only

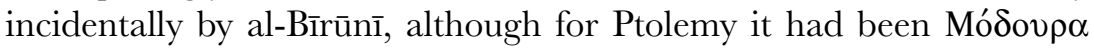

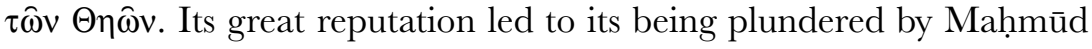
of Ghazni in 408/1018 and by many later Muslim rulers, more in an excess of iconoclastic zeal than in a settlement of the district; notably by Sikandar Lōdī c. 905/1500, who is reported to have destroyed many idols and to have prohibited head-shaving and ritual bathing. Some temples were allowed to be built in the tolerant reign of Akbar (the temple of Govind Dēva at nearby Vrindaban, erected by Mān Singh, even shows architectural borrowings from Mughal architecture); but

* "Mathurā," EI, VI, 839. 
Shāhjahān in 1046/1636-7 appointed a governor to "extirpate idolatry", Aurangzīb some 30 years later destroyed its finest temple and built a mosque on top of it, and Aḥmad Shāh Durrānī in 1170/1757 not only plundered the temples but butchered a large group of pilgrims. Otherwise, the city saw little of Islam, the Mēwātīs, in whose territories it lay, not being renowned for their orthodoxy.

\section{Monuments}

A Jāmi' Masjid, built in 1071/1660-1 (inscr. chronogram) by 'Abd al-Nabī, a governor under Aurangzīb, is an excellent building for its period, with fine inlay in encaustic tilework, four tall minārs, and two side pavilions with the curved-cornice "Bengali" roof flanking the courtyard which stands $4 \mathrm{~m}$. above road level; Aurangzīb's own mosque is rather effete.

\section{MeERUT*}

The city of Meerut (Mĩrath) is of considerable antiquity. It was the site of a pillar of Ashoka, one of the two taken by Fīrūz Shāh Tughluq to Delhi, and within the city are Buddhist remains dating from the 3rd century B.C.; but since these are not mentioned by the Chinese travellers Fa-hsien (4th century A.D.) and Hsüan-tsang (7th century), there had probably been an early decay of Buddhist influence. A strong fort was built here in the 11th century by the Hindu ruler of Baran (= Bulandshahr), originally surrounded by a moat and a wall with eight gates (other gates were added in Muslim times); this was the fort captured from the Dor Rājpūts by Quṭb al-Dīn Aybak in 588/1192, using this and the fort of Baran from which to overthrow the Gahādavāla Rājpūts and make his assault on Delhi. Meerut remained in Muslim control through the early sultanate of Delhi (the names of several iqtạ $d \bar{a} r$ sare recorded by the chroniclers Minhāj, 'Ișāmī, and Baranī); in $727 / 1326-7$ the forces of the Mongol invader Tarmashīinn were defeated at Meerut, but by $802 / 1399$ the city had been sacked and destroyed by Tīmūr.

\footnotetext{
* "Mīrath,” EI, VII, 113.
} 
There seems to have been some return to prosperity in Mughal times: the fort is mentioned in the $\bar{A}^{\prime} \bar{\imath} n-i$ Akbari . Meerut was briefly a copper mint under Akbar, and the Mughal emperors seem to have taken some interest in the buildings (repair of Jāmi' Masjid by Humāyūn; a couple of dargāhs, of Abū Yār Muhammad Khān (1039/1629) and Abū Muhammad Khān (1099/1688); the maqbara of Shāh Pīr of 1038/1628 erected by the order of Nūr Jahān, a red sandstone building with the characteristic wide four-centred Mughal arch (photograph in Meerut gazetteer, UP Govt., Lucknow 1963); the presence of a karbalā, c. 1009/1600, and two imāmbārās, indicates that some Shīa settlement had taken place. In the early 18th century, with the rise of the Sayyid brothers as kingmakers, there were many grants of land made in the Meerut area, and there was some industry in the form of indigo-processing and in the manufacture of the fine lambswool sānsla blankets; but after the invasion of Nādir Shāh in 1152/1739 the land fell into anarchy, and by the early years of the 19th century Meerut was ruinous and depopulated. The considerable gain in British prestige after Lord Lake's success in the battle of Delhi, 1803, led to the establishment of an extensive military cantonment at Meerut, whereby the city regained its prosperity to the extent of securing a reputation as one of the best laid-out towns in Upper India. The events of 1857, when the mutiny of the Bengal army started in Meerut, led to the final loss of all power by the ruling Mughal house

\section{Monuments}

Apart from those mentioned above, there are a few Muslim monuments, some of considerable antiquity, which have been but poorly described, and no photographs are available. The Jāmi 'Masjid, on the site of a former Buddhist temple, is said to have been erected in 410/1019 by Hasan Mahdī, a wazìr of Mahmūd of Ghazni; the dargāh of Makhdūm Shāh Wilāyat in the reign of Shihāb al-Dīn (= Mu izz al-Dīn) Ghūrī; and the maqbara of Sālār Mas'ūdī by Quṭb al-Dīn Aybak at the end of the 12th century (since he was killed in battle at Bharuch in 425/1034, and has cenotaphs in other Indian towns, this maqbara may refer rather to his cult as a folk-divinity). The gazetteers mention some "scores of other temples and mosques, of no particular interest", but no-one seems to have looked at them to see: although only some $65 \mathrm{~km}$. from Delhi, Meerut has been badly served by archaeologists. 
Other buildings within Meerut District include the Begam Samrū's palace (Dilkusha Kōthī) of 1822, at Sardhana; on a (pre-Muslim) mound south of the town of Barnawa are the dargāhs of Badr al-Dīn Shāh and Shāh 'Alā' al-Dīn (undescribed) and the maqbara of Pīr Sarwār, Persian inscr. dated 948/1541-2.

\section{MudGAL*}

This ancient fort in Karnataka state, together with Raichur, formed a principal defence of the Raichur $d \bar{o} \bar{a} b$, between the rivers Krishna and Tungabhadra, that continuous bone of contention between the Hindu kingdom of Vijayanagara and the Deccan Sultanates. The date of its foundation is unknown, but it seems to have passed from the possession of the Yãdava rulers of Devagiri (Daulatabad) to the Kākatīya kings of Warangal, and from the appearance of the cyclopean masonry of parts of the outer wall, it could well have been established under the former. Mudgal came first to the attention of a Muslim sultanate after the conquest of Devagiri (694/1295), when Malik Kāfür captured and garrisoned both Mudgal and Raichur when on his way to attack the Kākatīya capital of Warangal; but there are no records of how long Muslim sway was then maintained. After the establishment of the Bahmanī Sultanate in Gulbarga, Mudgal frequently changed hands between that sultanate and Vijayanagara; thus under 'Alä' al-Dīn Hasan Bahman Shāh, the founder of the sultanate, it formed, with Raichur, part of the Aḥsanābād-Gulbargā taraf under the able wazīr Sayf al-Dīn Ghūrī; it was lost for a time to the Vijayanagara ruler Bukka I, but recaptured in the wars of 767/1366 when the Bahmanīs used cannon for the first time, and it was presumably about this time that the defences of the fort were adapted for artillery.

The beginning of the reign of Dēvarāya I in Vijayanagara, 808/1406, saw a renewal of hostilities brought about by the notorious "war of the goldsmith's daughter", an accomplished young lady whom the rāja coveted; the Bahmanīs under Fīrūz were victorious, Dēvarāya had to pay a large indemnity, marry a daughter to Fīrūz, and cede the fortress of Bankapur, in the west of the $d \bar{o} \bar{a} b$, as a bridal gift. But the continual

* "Mudgal," EI, VII, 289. 
withholding of tribute from Vijayanagara led to more fighting in the $d \bar{o} \bar{a} b$ when Dēvarāya II, anxious to enlarge his dominions, again took Mudgal in $c .846 / 1442-3$, only to lose it again shortly afterwards.

The decline of the Bahmanī Sultanate under Shihāb al-Dīn Mạ̣mūd, with the incipient Barīd-Shāhī and 'Ādil-Shāhī powers now gaining in strength, left Mudgal under 'Ādil-Shāhī control, again with constant harrying from Vijayanagara; but the $d \bar{o}$ 'a $b$ did not come finally under Muslim control until the confederacy of the four Deccan sultans crushed the Vijayanagara armies decisively at the (so-called) battle of Talikota in $972 / 1565$.

\section{Monuments}

The seven inscriptions at Mudgal are all of the 'Ādil-Shāhī period. The fort with its ponderous walls is defended by a wide moat (sometimes as much as $50 \mathrm{~m}$. in width), with a bastioned scarp, a covert way, and a heavily bastioned counterscarp with round and square towers alternating, much as in Golkonda); the towers show signs of having been rebuilt for artillery. A range of hills defends the fort to the south-west. The Fath Darwāza to the north is defended by a strong barbican (again as in Golkonda), with an inscription of 996/1588, after 'Ādil-Shāh's death, although it has been suggested that the victory commemorated is the battle of Talikota of 23 years before; a bastion inscription of 982/1574 records the conquest of Bankapur. The southern gate is interesting as showing three gateways of different periods, the inner one of beamand-bracket construction with small trefoil arches in the guards' rooms; this is of the Hindu period, and there are many Hindu sculptures in the vicinity. The middle gateway, however, is arched, and the outer gate (Kāntī Darwāza) is, as the name implies, heavily studded with iron spikes as a defence against elephants. There are several buildings in the fort, now somewhat ruined: a central mound (Balā Hiṣār) held the royal buildings, of which a roofless baradari remains; an inscription of Muhammad 'Ādil Shāh of 1053/1643 records the building of a marble palace, called Gagan (?) Mahall - the reading mahall-i khakan is presumably for gagan "sky", as in Bijapur. An 'äshür-khāna, a naubatkhāna, some powder magazines, and an early mosque constructed of plundered Hindu pillars have been identified, and water for the garrison is provided by a large $b \bar{a}$ o $l \bar{\imath}$ (Hikranī b.) in the west of the fort. 


\section{NAGAUR*}

The walled town (also spelt Nagawr and Nagor) in Rajasthan is said to have derived its name from its traditional founders, the Nāga Rājputs. In the later 12th century it was controlled by the Chauhān (Chhamāna) ruler of Delhi, Prithvīrāja III, then by the Ghūrid Mu izz al-Dīn Muhammad, although there are indications of an earlier Muslim presence before the Ghürid conquest, under the old governments of Sindh and Multan. It remained an important stronghold for the sultanate of Delhi, controlling both Sindh and southern Rajasthan until the decline of the Tughluq dynasty in the late 14th century, when it fell into the hands of Muzaffar Shāh I of Gujarat; he gave the state of Nagaur to his brother Shams Khān Dandānī, and the Dandānī dynasty lasted for over a century until Muhammad Khān Dandānī submitted to Sikandar Lōdī in 915/1509-10. After the Lōdī period it passed to Rājā Maldev of Jodhpur, who built the fort and incorporated much old Muslim building in its walls. It fell again to the Delhi Sultanate under Shēr Shāh, subsequently becoming part of the Mughal empire until its final fall; thereafter it reverted to the Mahārājā of Jodhpur.

By the 14th century Nagaur had become a centre of the Chishti Șūfì order and was already a renowned home of Muslim mysticism and scholarship, starting with Shaykh Hamīd al-Dīn Suwali Nāgaurī (d. 673/1274) (early genealogy in M. Shokoohy, Corpus Inscriptionum Iranicarum, xlix (Rajasthan 1), London 1986, 68-86, and Pls. 62a-80c). In the 16th century, it was the birthplace and early home of Shaykh Mubārak Nāgaurī (911-1001/1505-93), later influential, as was his younger son Abu 'l-Faḍl 'Allāmī, at Akbar's court as an exponent of a more liberal and eirenic view of the role of Islam in India than that held by the rigorist 'ulam $\bar{a}$ ' who opposed Akbar's religious policies (see A. Ahmad, Studies in Islamic culture in the Indian environment, Oxford 1964, 168-9; S.A.A. Rizvi, Religious and intellectual history of the Muslims in Akbar's reign, Delhi 1975, 76-103).

\section{Monuments}

Inscriptions from many of the earlier buildings, including one from the time of Muhammad b. Sām, and several of the Khaljī and Dandānī

\footnotetext{
* "Nāgawr," EI, VII, 898; co-authored with C.E. Bosworth.
} 
periods, are set into the upper walls of the fort. The oldest standing monument, and the finest, is the Buland Darwāza, also known as Darwāza-yi Tārikīn, a gateway leading to the enclosure around the shrine of Shaykh Hamīd al-Dīn. An inscription refers to its construction in $733 / 1333$, i.e. in the reign of Muhammad b. Tughluq, but this must refer to a restoration, since the style and the surface decoration are more consonant with the buildings of Shams Dīn Iletmish; a fine Qur'ānic inscription above the gateway is in a typical 13th century chancery script. The Shamsī Tālà'ō, the Shamsī 'İdgāh and the Shamsī Masjid, in earlier writers attributed to Shams Dīn Iletmish, are in fact rather of Shams Khān Dandānī. The Shamsī Masjid, large and impressive, has a western prayer-hall in the beam-and-bracket style, with five domes (the central now fallen) and two tapering corner turrets resembling those of Lōdī buildings, faced by a maqsūura-screen of five arches, similar in type to mosques of Gujarat. Other mosques of a similar period (Ek mīnār kī Masjid, Sūrī Masjid) are also trabeate, but the Akbarī Masjid of $972 / 1564-5$ is entirely arcuate, in the early Mughal style. There are many small mosques of Mughal reigns up to Aurangzìb in the various mahallas of Nagaur city.

\section{NALDURG*}

This small town and its fort, standing above the ravine of the Bori river in Maharashtra, are one of the best fortified strongholds in the Deccan. The name, which also appears as Naldrug, is derived from durg (= Sanskrit, durga, "fort").

Naldurg does not figure in the Deccan campaign of Muhammad b. Tughluq, and so probably came into Bahmanī possession after the imperial forces had withdrawn, in the late 14th century; its stone fortifications, which appear to be of Bahmanī work although elaborated later under the 'Âdil Shāhīs of Bijapur, may have replaced an earlier Hindu (? Chālukya) mud fort. Thereafter, Naldurg incurs frequent mention in the dynastic squabbles of the Deccan, lying as it does on the border of the 'Ādil Shāhī and Niz̄ām Shāhī territories of Bijapur and Ahmadnagar respectively, having later even attracted the attention of the Quṭb Shāhīs of Golkonda. Thus Muhammad Khān, the brother of

* "Naldrug," EI, VII, 943. 
'Alā' al-Dīn Aḥmad II Bahmanī, in rebellion in 840/1436, is reported to have occupied Naldurg as well as Mudgal, Raichur, and Sholapur; after the fragmentation of the old Bahmani kingdom, when Naldurg became a bone of contention between the rival sultanates, there was a war between Qāsim Barīd and Yūsuf 'Ādil Khān in 897/1492, when Qāsim was humiliated; in 914/1508 Aḥmad Niẓām Shāh unsuccessfully demanded Naldurg from Yūsuf as his price for neutrality against the rival claims of Maḥmūd Shāh Bahmanī and 'Alī Barīd. In 938/1531 Amīr Barīd had entered into an alliance with Burhān Niẓām Shāh against Ismā'îl 'Ādil Shāh and marched on Naldurg, but was defeated by Ismāi îl; Vijayanagara entered the contest when in 970/1562-3 the lands of Husayn Nizām Shāh of Ahmadnagar were invaded by Rām Rāj of Vijayanagara, now allied to 'Alī 'Âdil Shāh of Bijapur; but Rām Rāj withdrew after his camp was flooded in the rains, whereupon 'Alī 'Ādil Shāh withdrew to Naldurg and carried out some rebuilding, including a dam across the river Bori, to improve the water supply to the garrison. In 989/1581, after the death of 'Alī 'Ãdil Shāh, Murtazā Nizām Shāh attempted to recover Sholapur and Naldurg, now with the help of Ibrāhīm Quṭb Shāh of Golkonda; but the allied forces, on seeing Naldurg's great strength, moved rather to Bijapur itself; the siege of Naldurg, however, was prolonged under the next Quṭb Shāhī sulțān, Muhammad Qulī Quțb Shāh, the following year.

In 1003/1595 Ibrāhīm 'Ādil Shāh of Bijapur invaded the Nizāam Shāhī kingdom; in an ensuing battle at Naldurg Ibrāhīm Niẓām Shāh was killed. But there was now a greater danger on the horizon, and the 'Ādil Shāhī and Quṭb Shāhī,forces were allied at Naldurg against the Mughals. During the Mughals' Deccan campaign the Nizāam Shāhī Sultanate was in 1046/1636 invaded by Shāhjahān's general Shā'ista Khān, who after his success turned his attention to the 'Ādil Shāhī kingdom, conquered Naldurg and occupied the region between Sholapur and Bidar, although the Mughal success was then short-lived; in 1087/1676 the Mughal general Bahādur Khān failed in a further siege against Naldurg, although Naldurg fell to the Mughals the following year; this was of course an important possession for the Mughals in view of the growth of the hostile Mārātha power. There seems to be no record of when Naldurg finally came into the possession of the Mārāthas. 


\section{Monuments}

The fort is an imposing building, but now disfigured with mean squatters' buildings. An interesting addition to its fortifications is a multilobed circular bastion on the south wall, similar to but smaller than the one at Golkonda fort. The water-palace and other palace buildings, and the mosque, have not been adequately described or published, but an inscription in the water-palace (Pāṇ̄ Mahall) refers to the erection of a dam in 1022/1613 (EIM, 1917-18, 3). There are illustrations of the Pānī Mahall and the multi-lobed bastion in ARADHS, 1917-18, Pl. III. Besides those within the fort, there are several mosque buildings in the vicinity of Naldurg which appear to be of the late 'Ādil Shāhī style and period.

\section{NARNALA*}

This hill-fort is located in the Berar region of the Deccan (now in Maharashtra State), at the southernmost end of the Satpura hills. The fortress is presumably pre-Muslim, since Firishta (Gulshan-i Ibrähīm $\overline{)}$ ), states that it was restored and repaired by Ahmad Shāh Bahman̄ between 828-31/1425-8, and the earliest buildings there appear to be of the Bahmanī period, although later the fort passed into 'Imād Shāhī hands. Narnala played an important role in the warfare of the rulers in the Deccan of the Bahmanīds, Khāndesh sulțāns, 'Imād Shāhīs and Niz̄ām Shāhīs, being held for the latter princes 979-1005/1572-97 till its capture by the Mughals.

\section{Monuments}

The fortifications comprise three distinct but conjoined forts, with a competent and still well-preserved water supply. There are insufficient remains of the old Jāmi' Masjid to relate it now to the characteristic 'Imād Shāhī style, although there are features of the excellent main central (Mahākālī) Darwāza, of 892/1487, which seem to have determined the later mosque architecture: a central arch of fine dressed stone within a larger arch, under a pylon crowned with trefoil merlons, and

\footnotetext{
* "Narnālā," EI, VII, 965.
} 
liberally decorated with stringcourses, embossed medallions and rosettes; there are flanking chambers and galleries, with projecting balconies on corbelled brackets, and fine lattice tracery. This is an architectural achievement of a high order, and important in the development of the 'Imād Shāhī style. The other buildings (hammām, bāradarì, stables, etc.) are of less value; there is also a small mosque of the time of Aurangzīb.

\section{NARNAUL*}

This ancient town in Haryana, some $130 \mathrm{~km}$. south-west of Delhi, was probably (Ishwari Prasad, Life and times of Humayun, 95) the birthplace of Shēr Shāh, his family having been associated with the place for some time. But Narnaul has much older Islamic associations, with the inscription at the Dargāh of Shāh Wilāyat showing that the saint was living here in and before $531 / 1137$, i.e. over 50 years before the Muslim conquest of Delhi; his dargäh shows signs of the pre-Muslim style of coffered-roof construction, familiar from such early sites as Ajmer and Bayana (description and discussion in K.V. Soundara Rajan, Islam builds in India, Delhi 1983, 89-90), and may well be contemporary with the saint. Indeed, the town could well be earlier, since the approach from a distance reveals it as an obvious tell; but unfortunately Narnaul has not been excavated. In the 18th century it was at times held by Rājput princes and the Marāthās. Its Muslim Nawwāb was involved in the Sepoy Mutiny of $1857-8$, hence the town was afterwards awarded to the loyal maharajā of Patiala.

\section{Monuments}

There is evidence of all phases of Indian Muslim building, from early Delhi Sultanate, through Khaljī, Tughluq and Lōdī, to early and late Mughal and to Mughal-inspired Rājpūt. The earlier phases are mostly to be seen in and around the dargāh complex; many Lōdī-style buildings, frustratingly but typically undated, occur not only in Narnaul itself but also sporadically all the way to Delhi (at, e.g., Rewari, Sohna and Gurgaon); the best example of the late-sultanate styles is in the tomb of Ibrāhīm Khān Sūr, which stands within the dargāh complex. Ibrāhīm

\footnotetext{
* "Nārnawl," EI, VII, 965-6.
} 
was the grandfather of Shēr Shāh, and the building of this tomb was Shēr's first preoccupation after his arrival in Delhi, having expelled Humāyūn in $947 / 1540$. It is a tall square structure in polychromatic stonework (sandstone, schist and marble), well decorated with carved and inlaid stone, the dome surrounded by a high octagonal drum with ornate polychrome guldastas and with chhatris at the four corners; the walls, with a slight batter, and the trabeate entrance doorways, continue the traditions of the Lōdī style. Other buildings show the Mughal styles at their most felicitous, with tombs and pavilions set within gardens and tanks, showing again fine stonework, such as the Jal Mahall and the tomb of Shāh Qulī Khān, the latter introducing the octagonal type. Within the town there is, among other fine buildings, a particularly fine havêtè, the Chattā Rāì Bāl Mukund Dās, with courtyards surrounded by elegant marble pillars, fountains, projecting balconies, richly bracketed eaves, and culminating in a curved-cornice baradar of the "Bengali" style introduced to North India in the time of Shāhjahān and later to be so popular in Rājpūt building.

\section{THALNER*}

Now nothing more than a large village in Dhulia District, Maharashtra, Thalner was once of importance as the site of an imposing and powerful fort overlooking a wide sweep of the Tapti river, and of the tombs of the Faruqi Khans of Khandesh. These monuments are mentioned in the standard histories and accounts of Indian Muslim buildings, but they have not hitherto been accurately described, and no deep study of them is known to exist. The account given in the old Bombay Gazetteer reveals more about the authors than the monuments.

The tombs of the Khans, with some monumental tombs of their associates and with many individuals and some grouped graves on numerous plinths, stand on open ground to the north-east of the modern village. The only other antiquities at this site are the idgah to the west of the village, and the crumbling ruins of Thalner fort, on the river bank less than $1 \mathrm{~km}$. to the south of the village. These we did not investigate in detail; but, for purposes of comparison, we visited the town of Burhanpur, the major town of Khandesh and the former Faruqi

* Unpublished field report. 
capital. The modern village is almost entirely Hindu now; but I had a long conversation with an elderly Muslim gentleman who recounted to me the local traditions. Since these were delivered in a mixture of Dakhni Urdu and Marathi from a mouth much hardened by pan, I may not have recorded them all accurately; but he is my source for the attributions below. We have found it more convenient, in general, to refer to the tombs and mosque-walls by numbers, arbitrarily given by ourselves since we could discover no previous system of numbering.

Tomb 1, the southernmost, is said to be that of a brother of Mubarak Khan. It is an octagon of grey trap stone formerly standing on a high platform which has now collapsed towards the west. The dome has completely fallen, as have the west and north-west walls above plinth level; and only a little of the façade of the south-west and north walls remains. The plinth does, however, reveal that the only entrances to the tomb were on the east and south. There are no inscriptions, but each wall is elaborately decorated inside and out; each face is slightly different. The relief-carved designs are complicated, but most recur in the other tombs although in less confusion. This is the only octagonal tomb in the group; no instance of a comparable tomb in either Gujarat or Malwa (the two regions alleged, in the standard histories, to have the closest affinities with Khandesh) occurs to me.

The platform on which Tomb 1 stands is continued northwards to form a common plinth for Tombs 2, 3 and 4. Tomb 2, square and of lighter stone than Tomb 1, is said to be that of Altamish Khan. The building carries a single dome; no trace is visible from the ground of corner domes, nor are there any interior indications to suggest their presence. Externally there are heavy chhäja brackets, one slab of the chhajja remaining in the west wall. Each side is composed of three arch shapes filled in with masonry of irregular shape but of good jointing (but I did not get the impression that the tomb started as an open pavilion which was later filled in; this style of construction seems to have been deliberate, and I doubt whether a simple open pavilion could have supported the massive dome). The arches rest on pillars of Hindu style, of several different patterns and not disposed symmetrically, which being of the same thickness as the walls are visible on both the exterior and the interior faces of each wall, three of such pillars appearing at each corner. The south door, the only entrance, appears to be a concrete restoration. The tomb is square inside, the west and east walls being completely plain without windows. The west wall interior is finely worked into three mihrab niches, although the position of the mikrab is 
not differentiated on the exterior. Over the window on the centre of the north wall is a finely written inscription; of the two flanking blind niches on the walls, that on the east is especially deep. At the time of our visit this tomb was being used as a residence by the nominal chowkidar of the tombs, who was absent both at our preliminary enquiry and for our subsequent visit, and we were enable to see the interior only through the courtesy of the local Sub-Inspector of Police, who had a duplicate key.

Tomb 3, the most important of the whole series, that of Miran Mubarak Khan, is also generally square on exterior plan, but with the central bay of the three on each side projecting and flanked by engaged octagonal buttresses or pilasters, which continue upwards above the level of the chhajja. On the south wall there are inscriptions around the door and on the pilasters, and fragments of a band of inscription above chhajja level and below the merlons (there is also a fragment of this band on the west wall). Owing to encroaching vegetation it was not possible to see all of the inscription; and unless the pipal seedlings that have established themselves on the roof are quickly removed the tomb and its inscriptions will suffer irreparable damage. The tall stilted dome was flanked by four corner domes, traces of which remain. The south entrance-door has an inner architrave which at top carries a square projection resembling the lalata-bimba on Hindu temple doorways; the tympanum above was formerly filled with jali work. The side bays on each face show open windows which originally had projecting sills carried on corbelled brackets and canopied above (marks on the stone show the extent of the side projections of the canopy) with hanging lotus buds. The central arches on each bay show the so-called 'spearhead fringe'.

The interior of the tomb is an octagon formed by cutting off rooms at each corner which open to the exterior by the canopied windows already mentioned. Each wall of this octagon is a great arch of the height of the hexadacagon which forms the lowest tier of the phase of transition; within these arches and in the same plane are smaller arches, larger at the corners than on the cardinal-point walls; all these are flanked by niches, the heights of which are not entirely regular. The inner floor (no graves or cenotaphs are now present) is at ground level, with a surrounding plinth on which the internal arches of the octagon, and the corner rooms, rest. There are small oblong chambers at the centre of each wall, the southern one of which forms an 
entrance porch. The dome interior is ribbed, and is well decorated by concentric bands of carving.

The tomb has an immediate superficial resemblance to the tomb of Darya Khan at Mandu; but it differs considerably from that monument in its internal arrangement and decorative motifs, and there are also many points of difference in the exteriors of the two tombs. It should be pointed out in this connection that although Mandu has been excellently served by G. Yazdani in Mandu, the city of joy, the description and the illustrations of the monuments are insufficient to permit of detailed comparisons, and deep study of the architecture of these monuments is still needed.

Tomb 4, the westernmost of the main group at Thalner, is said to be that of 'Adil Khan. This is built of a fine stone, more reddish in tone than that of its neighbours. The drum of the main dome, and the bases of the four corner engaged domes, is of a light red brick which was originally plastered over. The stone jointing of the masonry is again of excellent workmanship, although the stones are of irregular size and are not laid to regular courses. The tomb is square on plan, with its west and east walls completely unadorned on the exterior except for the chhajja; this is carried on heavy stone corbels, well carved, which support transverse lintels with further carving on their undersides (the heavy chhajja slabs have mostly fallen, and most of a chhajja structure on the west wall, a reinforced concrete restoration, has come away). Below the corbels and in vertical register with them is a row of bosses on each wall which appear to have supported an outer row of brackets; sockets cut in the undersides of the lintels seem to support this view. On the south façade there are four blind niches each surmounted by a characteristic merlon device (either three or five merlon shapes, flanked by two half merlons) which occurs also no the decoration of the other tombs. The doorway, as on Tomb 3, is on the south; it has a peculiar lalata-bimba boss, as in that tomb, but in this case bears a simple 'Allah motif. The interior of this tomb is square, with little decoration or variation except for deep cells in each side in the thickness of the walls. The engaged corner domes are a characteristic feature of the Muslim architecture of Malwa; but other Malwa characteristics do not appear in this tomb. The treatment of the chhajja brackets in double rows is more suggestive of the eaves supports in the later stages of the buildings of Bijapur.

Tomb 5, the attribution of which I was unable to ascertain, is small, and has a tall stilted dome haunched abruptly. Where the larger tombs 
have corner domes, this has merely four corner guldastas of simple shape standing in the angles of the flat roof.

Tomb 6, called locally the tomb of Bibi Faruqi, differs from the tombs of the main group in being of brick with a stucco surface. The single dome is shallow. The blind merlons which form a false parapet (actually below the level of the flat roof) meet at the corners of the tomb in fluted guldatasa, recalling those of the Bahmani buildings at Bidar. Below these blind merlons is a stringcourse of brick-on-angle, with the re-entrance angles rounded off into a curve with an infilling of stucco. The same decorative pattern recurs inside the tomb in the corner pendentives of the phase of transition. The single entrance is on the south, its recessive curve also recalling the early Bahmani buildings; there are pierced openings centrally on the other three walls (i.e., there is no mikrab), flanked with blind niches.

Tomb 7, a small square stone building, heavily whitewashed, contains a single marble grave - the finest cenotaph in Thalner - said to be that of Hazrat Shah Raje, a disciple of 'Ayn al-Mulk of Delhi. There is no chhajja or parapet, but a row of blind merlons appears at the top of the cube. The dome is more or less hemispherical, not stilted, and is the only one at Thalner still to carry an amalaka and kalasa finial.

Tomb 8 is a ruined building of larger size, said to be that of the Wazir al-a'zam Muhi al-Din. The dome has fallen, damaging the single grave below (this is to the east of the central axis and therefore is presumably a subsidiary grave). Most of the external ashlar facing has also fallen, although what remains is of superb quality with intricate decoration. The internal plan of this tomb is similar to that of Tomb 3, and most of the internal ashlar remains. The interior arches and niches are of slightly varied design. There are corner chambers, as in Tomb 3 , above which were originally corner domes.

Tomb 9 is also small, and is attributed to the darogha Amin al-Din. The exterior, of dark trap stone, has an encircling stringcourse at the level of the haunch of the door arch, and heavy brackets at eaves level which have carried a chhajja. There is a single door on the south side, with window openings on the other three sides (again, there is no mihrab) whose haunches are cut by the stringcourse.

Tomb 10, said to be that of Bibi Areza, stands remote from the main group near Mosque-wall 4, and is on a high plinth. A small cubical structure surmounted with a tall dome, it is of brick with a facing of stucco, with a single entrance on the south; there are window openings on the other three sides, with no mikrab. Flanking the openings on the 
exterior are narrow engrailed arched niches of a shape usually associated with late Mughal buildings. The interior is a simple square; there are traces of colour decoration in the stucco of the dado, below the roof, and in the roof arches. Below a band of a coloured pattern of crosses is a highly polished fillet of cunam with some graffiti in good nastaliq in black ink, somewhat obscured by whitewash. The stucco cenotaph is dilapidated.

There is no mosque on the site (I was told that a small mosque in the village, which I did not see, was quite recent); the ritual cihal and urs observances for those buried in the tombs and in the many graves, grouped and individual, which cover the site, would have been provided for by the open mosque-walls, of which there are four in a more or less ruinous condition. They are simply short massive walls running approximately north-south, with a niche on the east side whose function is to indicate the qibla to a worshipper facing west; corresponding to the niche is a buttress on the western side. Mosque-walls 1, 2 and 4 are in poor repair (Mosque-wall 2 seems likely to collapse soon), although the corner guldastas of these are interesting in that they resemble the two-staged guldastas of the smaller mosques and idgah of Burhanpur. Mosque-wall 3, however, is a much more elaborate structure of seven bays, with much looted Hindu material built into it as pillars and pillar bases. There are few graves to the east of Mosque-wall 1, which may imply that the graveyard had once a greater eastward extent. Only Mosque-wall 3 was considered with detailed survey, although the positions of the others were accurately recorded on the site plan. No attempt was made to record the positions of the individual graves.

The Faruqi idgah, to the west of the village, was not surveyed; nor was the ruinous fort to the south of the village. This has suffered much from floods and erosion, for it stands very near the north bank of the river Tapti. Part of the west wall, up to below the level of the battlements, remains, and parts of large circular buttress towers are still visible. The fort contains no standing buildings, although there are traces of the walls of a mosque and hauz and of a hammam. At the top of the mound are the ugly tombs of two British officers, uninscribed, who are said to have been killed in 1818 .

This preliminary study has revealed that the tomb buildings of Thalner are of great variety, of materials, construction and decoration alike; almost the only unifying feature, and that not common to the entire group, is the 'N-plus-two-halves' merlon pattern over niches referred to above. There are features which recall certain elements in 
the buildings of Malwa, of the Bahmanis of Gulbarga and Bidar, of Bijapur, and occasionally other Faruqi buildings at Burhanpur. The only positive conclusion which emerges clearly is that it is not possible to define a single and unitary Faruqi or Khandesh style.

\section{Acknowledgements}

The site was visited in December 1972 by a small team consisting of Garry Martin and George Michell, architects, with myself as director. Messrs Martin and Michell measured the major buildings at the tomb site, in order to prepare plans, elevations and certain sections, and a general site plan. I took some 300 photographs, and am responsible for the textual research and for all expressions of opinion presented above. The team would like to record its gratitude firstly to Shri S.R. Rao, Superintending Archaeologist of the South-Western Circle, ASI, with whose permission, approval and, indeed, encouragement the project was undertaken. The Headmaster of the N.B.G. High School, Thalner, responded enthusiastically to a request for assistance, and not only arranged for the team's accommodation and much hospitality in Thalner but deputed his senior English master, Shri Shivaji B. Patil, as liaison officer; without the latter's constant help and interest the team's task would have been almost impossible. Our gratitude is also due to the Chairman, Secretary and Council of the V.K.S. Society of Thalner for putting a room at the team's disposal; to Shri Dingal and Shri Dongar, locally recruited as foremen; and to the villagers of Thalner for their unfailing help and courtesy to the first Europeans to visit their village in living memory. 